\title{
De arbeidsmarkt naar opleiding en beroep tot 2024
}

Citation for published version (APA):

Bakens, J., Bijlsma, I., Dijksman, S., Fouarge, D., \& de Lombaerde, G. (2019). De arbeidsmarkt naar opleiding en beroep tot 2024. ROA. ROA Reports No. 007 https://doi.org/10.26481/umarep.2019007

Document status and date:

Published: 15/10/2019

DOI:

10.26481/umarep.2019007

Document Version:

Publisher's PDF, also known as Version of record

\section{Please check the document version of this publication:}

- A submitted manuscript is the version of the article upon submission and before peer-review. There can be important differences between the submitted version and the official published version of record.

People interested in the research are advised to contact the author for the final version of the publication, or visit the DOI to the publisher's website.

- The final author version and the galley proof are versions of the publication after peer review.

- The final published version features the final layout of the paper including the volume, issue and page numbers.

Link to publication

\footnotetext{
General rights rights.

- You may freely distribute the URL identifying the publication in the public portal. please follow below link for the End User Agreement:

www.umlib.nl/taverne-license

Take down policy

If you believe that this document breaches copyright please contact us at:

repository@maastrichtuniversity.nl

providing details and we will investigate your claim.
}

Copyright and moral rights for the publications made accessible in the public portal are retained by the authors and/or other copyright owners and it is a condition of accessing publications that users recognise and abide by the legal requirements associated with these

- Users may download and print one copy of any publication from the public portal for the purpose of private study or research.

- You may not further distribute the material or use it for any profit-making activity or commercial gain

If the publication is distributed under the terms of Article $25 \mathrm{fa}$ of the Dutch Copyright Act, indicated by the "Taverne" license above, 


\section{De arbeidsmarkt naar opleiding en beroep tot 2024}

\section{ROA Rapport}

ROA-R-2019/7

Researchcentrum voor Onderwijs en Arbeidsmarkt | ROA Research Centre for Education and the Labour Market / ROA 


\section{Colofon}

(c) Researchcentrum voor Onderwijs en Arbeidsmarkt (ROA). Niets uit deze uitgave mag op enige manier worden verveelvoudigd zonder voorafgaande schriftelijke toestemming van de directeur van het ROA.

\section{Researchcentrum voor Onderwijs en Arbeidsmarkt}

School of Business and Economics

Maastricht University

email: secretary-roa-sbe@maastrichtuniversity.nl

website: www.roa.nl

\section{Redactie en productie}

Researchcentrum voor onderwijs en arbeidsmarkt (ROA)

\section{Vormgeving}

ROA secretariaat, Maastricht

ISBN: 978-90-5321-589-0

december 2019 


\section{Addendum}

1. Aanpassing in Tabel 1.5 op pagina 21

Mbo4 uitbreidingsvraag (\%) is $1,1 \%$

Mbo4 vervangingsvraag (\%) is $2,7 \%$

\section{Aanpassing in tabel 2.1 op pagina 27}

Mbo4 gezondheidszorg en welzijn ITA is 1.06

Mbo4 gezondheidszorg en welzijn typering arbeidsmarktperspectieven is matig

\section{Aanpassing tabel $\mathbf{3 . 2}$ op pagina 46}

Mbo4 gezondheidszorg en welzijn uitbreidingsvraag:

- Aantal (6 jr.) is 45.700

- Totaal (6 jr.) is $14 \%$

- Gem. jaarlijks is 2,2\%

\section{Aanpassing tabel 3.4 op pagina 51}

Mbo4 gezondheidszorg en welzijn vervangingsvraag

- Aantal (6 jr.) is 56.000

- Totaal (6 jr.) is $17 \%$

- Gem. jaarlijks is $2,7 \%$

\section{Aanpassing tabel 3.6 op pagina $\mathbf{5 5}$}

Mbo4 gezondheidszorg en welzijn baanopeningen

- Aantal (6 jr.) is 101.700

- Totaal (6 jr.) is $31 \%$

- Gem. jaarlijks is $4,6 \%$

- Belang van de vervangingsvraag is $55,1 \%$ 


\section{INHOUD}

Ten geleide $\quad$ v

Samenvatting ix

Doel en opzet xiii

01 De arbeidsmarkt in vogelvlucht $\quad 1$

$\begin{array}{ll}1.1 & \text { Inleiding } \\ \end{array}$

1.2 Actuele ontwikkelingen op de arbeidsmarkt 1

1.3 Verwachtingen voor arbeidsvraag en -aanbod op de middellange termijn 13

1.4 Verwachte werkgelegenheidsontwikkeling naar bedrijfssector 14

1.5 Verwachte werkgelegenheidsontwikkeling naar beroepsklasse 16

1.6 Verwachte werkgelegenheidsontwikkeling naar opleidingsniveau 17

1.7 Verwachte arbeidsmarktperspectieven naar opleidingsniveau tot $2024 \quad 19$

1.8 Conclusie $\quad 22$

02 Aansluiting tussen onderwijs en arbeidsmarkt $\quad 25$

$2.1 \quad$ Inleiding 25

2.2 Toekomstige arbeidsmarktperspectieven naar opleiding 26

2.3 Toekomstige knelpunten in de personeelsvoorziening naar beroep 30

2.4 Aanpassingsmechanismen op de arbeidsmarkt 34

2.5 Conclusie $\quad 39$

03 Ontwikkelingen in vraag en aanbod 2019-2024 41

$\begin{array}{lll}3.1 & \text { Inleiding } & 41\end{array}$

3.2 Uitbreidingsvraag 41

$\begin{array}{ll}3.3 & \text { Vervangingsvraag }\end{array}$

3.4 Baanopeningen $\quad 52$

3.5 Arbeidsmarktinstroom 56

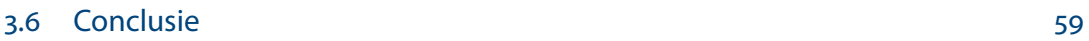


Bijlage A: Centrale begrippen bij de arbeidsmarktprognoses

Bijlage B: Classificaties naar bedrijfssector, beroep en opleiding

Bijlage C: Verkrijgbare arbeidsmarkt-informatie per bedrijfssector, beroepsgroep en opleidingstype

Bijlage D: Aansluitingsindicatoren recent gediplomeerden 


\section{TEN GELEIDE}

Op de arbeidsmarkt moeten vraag en aanbod van kennis en vaardigheden op elkaar worden afgestemd. Voor werkgevers zijn de taken die op het werk gedaan moeten worden bepalend voor hun vraag naar kennis en vaardigheden. Deze taken zijn gebundeld in beroepen. Studiekiezers en werkzoekenden bouwen kennis en vaardigheden op in het onderwijs en door zich leven lang te blijven ontwikkelen. lemands opleidingsniveau en -richting zijn belangrijke indicatoren voor de kennis en vaardigheden die hij of zij heeft. Voor een optimale match tussen vraag en aanbod op de arbeidsmarkt is een kwantitatief en kwalitatief goede aansluiting tussen het beroepenveld en opleidingsaanbod zeer belangrijk.

Omdat het altijd tijd kost om kennis en vaardigheden op te bouwen is transparante informatie over de toekomstige arbeidsmarkt belangrijk voor jongeren die een opleiding moeten kiezen, maar ook voor werkgevers die zich een beeld willen vormen over mogelijke toekomstige knelpunten in hun personeelsvoorziening om daar zo goed mogelijk op te kunnen anticiperen. Dezelfde informatiebehoefte speelt bij arbeidsbemiddelaars en uitzendbureaus die een belangrijke rol spelen in de allocatie tussen vraag en aanbod op de arbeidsmarkt en de overheid die streeft naar een optimaal opleidingsaanbod en een goed werkende arbeidsmarkt.

Het Project Onderwijs-Arbeidsmarkt (POA) heeft als belangrijkste doel om een gedetailleerd beeld te geven van de arbeidsmarktperspectieven voor de middellange termijn over de volle breedte van de arbeidsmarkt. Daarbij kijken wij zes jaar vooruit, omdat dat de termijn is waarop jongeren die nu een opleiding kiezen na het behalen van hun diploma op zoek gaan naar een baan. Om dat te kunnen doen maken we prognoses voor de in de komende jaren verwachte vraag (uitbreiding, vervanging en substitutie) en het verwachte aanbod (instroom vanuit het onderwijs en kortdurige werkloosheid). Op basis van deze prognoses presenteren we voor iedere opleiding de Indicator Toekomstige Arbeidsmarktperspectieven en voor iedere beroepsgroep de Indicator Toekomstige Knelpunten naar Beroep. Daarnaast geven we zowel voor opleidingen als beroepen een aantal risico-indicatoren, zoals de conjunctuurgevoeligheid van deelmarkten en uitwijkmogelijkheden naar verschillende beroepen en sectoren. Deze indicatoren, alsmede enkele kernindicatoren voor de actuele aansluiting onderwijs- 
arbeidsmarkt voor alle onderwijssectoren, zijn opgenomen in het door ROA ontwikkelde ArbeidsmarktInformatieSysteem (AIS).

Het is belangrijk om te beseffen dat de hier gepresenteerde arbeidsmarktprognoses betrekking hebben op de middellange termijn met het doel om de actoren op de arbeidsmarkt richtinggevende informatie te geven voor hun opleidingskeuze, wervingsbeleid of bij- en omscholingsbeleid. De arbeidsmarktprognoses zijn uitdrukkelijk niet bedoeld voor het simpelweg doorrekenen van een kwantitatieve verschil tussen verwachte aanbod en vraag om dit verschil vervolgens te interpreten in termen van 'tekorten' waarbij het opleiden van meer gediplomeerden de enige oplossing is en 'overschotten' waarbij het sluiten van opleidingen de enige oplossing is. Een dergelijke benadering onderschat de vele wijzen waarop de arbeidsmarkt kan reageren op discrepanties tussen vraag en aanbod. Zoals gezegd hebben onze prognoses als doel om zowel studiekiezers als werkgevers van informatie te voorzien die het hen mogelijk maakt om te anticiperen op de verwachte arbeidsmarktontwikkelingen naar opleiding en beroep. Het rapport opent dan ook met een inleidend hoofdstuk waarin de gebruiksdoelen van de prognoses en de globale opzet van het prognosemodel worden besproken.

Het rapport is verder opgebouwd uit drie hoofdstukken. Hoofdstuk 1 begint met een overzicht van de recente macro-economische ontwikkelingen op de arbeidsmarkt, waarbij wordt ingegaan op het verband tussen werkloosheid, vacatures en lonen in Nederland. Vervolgens wordt een globaal overzicht gegeven van de verwachte arbeidsmarktontwikkelingen voor de periode tot en met 2024.

In hoofdstuk 2 bespreken wij de verwachte ontwikkeling in de vraag-aanbod verhoudingen naar opleiding en beroep tot 2024 aan de hand van indicatoren voor de toekomstige arbeidsmarktperspectieven naar opleiding voor de studiekiezers en de te verwachten knelpunten in de personeelsvoorziening naar beroep voor werkgevers. De analyses laten zien dat de huidige knelpunten in de personeelsvoorziening, met name voor de opleidingen en beroepen in de zorg, techniek en het onderwijs, naar verwachting tot 2024 zullen aanhouden. Hier liggen derhalve de beste perspectieven voor studiekiezers. Voor gediplomeerden in de economisch-administratieve richtingen is de markt daarentegen erg ruim en kunnen werkgevers eenvoudig voldoen aan hun personeelsbehoefte. Hoofdstuk 3 beschrijft in meer detail de verwachte ontwikkelingen in de uitbreidingsvraag, de vervangingsvraag, de baanopeningen en de arbeidsmarktinstroom die gezamenlijk de perspectieven naar opleiding en beroep bepalen.

De eindredactie van De arbeidsmarkt naar opleiding en beroep tot 2024 is in handen van de projectleider Prof. dr. D. Fouarge. Aan het rapport hebben verder meegewerkt dr. J. Bakens, I. Bijlsma, S. Dijksman, en G. de Lombaerde. M. Boere zorgde voor secretariële ondersteuning bij de totstandkoming van dit rapport.

De rapportage vindt plaats in het kader van het Project Onderwijs-Arbeidsmarkt (POA) dat het ROA in 1986 is gestart in opdracht van het Ministerie van Onderwijs, Cultuur 
en Wetenschap (OCW.). Het project wordt door NRO bekostigd (dossiernummer 405-17900) met bijdragen van het Ministerie van OCW, het Ministerie van Landbouw, Natuur en Voedselkwaliteit (LNV), het Ministerie van Binnenlandse Zaken en Koninkrijksrelaties (BZK) en het Ministerie van Sociale Zaken en Werkgelegenheid (SZW), almede met aanvullende bekostiging daar het UWV Werkbedrijf, de stichting Samenwerking Beroepsonderwijs Bedrijfsleven (SBB), en Randstad Nederland.

Het ROA is de leden van de POA Programmacommissie en de commissie van financiers zeer dankbaar voor hun deskundige en enthousiaste begeleiding van het project: Prof. dr. H. Ganzeboom (voorzitter begeleidingscommissie, Vrije Universiteit Amsterdam), R. van der Ven, R. Hoffius, E. Meeuwsen (OCW), A. de Pleijt (SZW), M. van der Ligt (BZK), C. Loef (LNV), drs. M. van Smoorenburg (UWV WERKbedrijf ), drs. H. Wink (SBB), B. van Krimpen (Randstad Nederland), H. Daale (Leido), F. van der Mooren (Centraal Bureau voor de Statistiek), B. Scheer (Centraal Planbureau) en C. van Nahuijs (LDC).

Maastricht, december 2019

Prof. dr. A de Grip

Directeur ROA 



\section{SAMENVATTING}

Over het algemeen zijn de perspectieven voor gediplomeerden goed...

Alhoewel de economische groei stabiliseert, zijn de perspectieven voor 2019-2024 voor recent gediplomeerden over het algemeen goed. Tussen verschillende opleidingsniveaus en -richtingen zijn er echter grote verschillen, waarbij meestal geldt dat de arbeidsmarktperspectieven voor de hogere opleidingsniveaus beter zijn. De gediplomeerden uit de techniek en ICT, onderwijs en gezondheidszorg op bachelor en master niveau hebben de beste vooruitzichten.

\section{...met name de vraag naar afgestudeerden techniek en ICT, gezondheidszorg en onderwijs op bachelor- en masterniveau is groot}

De overwegend goede arbeidsmarktperspectieven voor gediplomeerden beïnvloeden op hun beurt hoe makkelijk werkgevers arbeidskrachten kunnen vinden met een specifieke opleidingsachtergrond voor een bepaald beroep. Met andere woorden, hoe goed het aanbod aansluit op de vraag. De toekomstige knelpunten in de personeelsvoorziening zijn het grootst in de zorg en welzijn, techniek en ICT en in het onderwijs. Vooral voor de eerste twee lijken er minder alternatieven voor een bepaalde opleidingsachtergrond in een beroep te zijn, waardoor het moeilijker is om geschikt personeel te vinden. Wat het onderwijs betreft, zijn de knelpunten het gevolg van een lage instroom van gediplomeerden met deze opleiding. Ook speelt mee dat werkenden met een onderwijs achtergrond in andere functies terecht komen. De grote vraag naar werkenden met een technische of ICT-opleiding kunnen we toeschrijven aan de toenemende digitalisering die alle sectoren van de economie treft. De krapte aan personeel in de gezondheidszorg en in het onderwijs, waar momenteel ook veel aandacht voor is in beleidsdiscussies, zal naar verwachting de komende zes jaar aanhouden. Het verbeteren van de arbeidsvoorwaarden en het imago van deze beroepen zou er aan bij kunnen dragen dat jongeren hier vaker voor kiezen. Voor de commerciële beroepen, economische en administratieve beroepen, en transport en logistiek beroepen, worden er vrijwel geen problemen verwacht voor de werving van personeel. De instroom van gediplomeerden die deze beroepen kunnen uitoefenen is groot genoeg om aan de vraag van werkgevers te voldoen. 


\section{Vooral de vervangingsvraag zorgt voor baanopeningen}

Over de komende zes jaar worden er meer dan 2 miljoen baanopeningen verwacht. Het feit dat mensen vervangen moeten worden die (tijdelijk) de arbeidsmarkt verlaten wegens o.a. werkloosheid, migratie, (vervroegde) pensionering, kinderzorg en arbeidsongeschiktheid, zorgt voor het overgrote deel van de baanopeningen. De vervangingsvraag blijft daarmee de komende jaren veruit de belangrijkste component van het aantal baanopeningen. Met 1,6 miljoen werknemers die naar verwachting vervangen zullen moeten worden, bedraagt dit aandeel ongeveer drie kwart. De rest van de baanopeningen wordt bepaald door de verwachte baancreatie, goed voor ruim 460.000 extra werkenden. De beroepen waarvoor de meeste vervangingsvraag wordt verwacht zijn de bedrijfseconomische en administratieve beroepen, de transport en logistiek beroepen, de technische beroepen en de commerciële beroepen. In de ICT-beroepen is door de relatief jonge leeftijd van werkenden de vervangingsvraag laag, zodat ruim de helft van de baanopeningen ontstaat door de uitbreidingsvraag.

\section{Extra werkgelegenheid in de zorg en techniek}

De grootste werkgelegenheidsgroei wordt verwacht voor de zorg en welzijn beroepen en de technische beroepen. Dit verklaart gedeeltelijk de goede arbeidsmarktperspectieven voor gediplomeerden met een opleiding die aansluit bij deze beroepen. De enige beroepsklasse waar krimp wordt verwacht zijn de agrarische beroepen. Een uitleg hiervoor is dat de mechanisering en schaalvergroting in de sector verder doorzet mede door de technologische ontwikkeling.

\section{Steeds meer hoog opgeleiden werkenden in Nederland}

In de periode van 2019 tot 2024 zullen er naar verwachting ongeveer 1,6 miljoen gediplomeerden de arbeidsmarkt instromen. Door de demografische ontwikkelingen groeit dit aantal niet, maar de samenstelling verandert ten opzichte van de afgelopen jaren. Voor mbo niveau 2 en 3 wordt een daling van de instroom naar de arbeidsmarkt geprognostiseerd, voor mbo 4, bachelor en master een toename. De grootste instroom wordt verwacht voor de mbo opleidingen in de sectoren ICT, media en vormgeving en gezondheidszorg en welzijn, de bachelor dienstverlening en de bachelor en master opleidingen in de sector journalistiek, gedrag en maatschappij.

\section{Een historisch lage werkloosheid, maar baanzekerheid laag voor laagopgeleide jongeren}

De economische groei van de voorbije jaren neemt momenteel af en de werkloosheid is historisch laag. Dit geldt voor alle leeftijdscategorieën. Voor de jongeren, die het hardst werden getroffen door de kredietcrisis van 2008, daalde de werkloosheid van $13,2 \%$ in 2013 naar $6,7 \%$ in 2019. Over het algemeen blijft de jeugdwerkloosheid echter structureel een stuk hoger dan voor de andere leeftijdsgroepen, vooral voor laagopgeleide jongeren ( $9 \%$ in 2019). Hoewel laagopgeleide ouderen ook vaker werkloos zijn, zijn de verschillen naar opleidingsniveau voor de oudste leeftijdsgroepen kleiner dan 
onder jongeren. Het aandeel jongeren met een flexibele arbeidsrelatie nam in de voorbije jaren fors toe en bedraagt momenteel bijna $70 \%$. Deze flexibilisering vergroot de baanonzekerheid onder jongeren.

\section{Achterblijvende lonen}

De arbeidsmarktkansen van werkenden zijn duidelijk beter als het opleidingsniveau hoger is: daar waar na de kredietcrisis in 2008 laagopgeleiden zowel fors inleverden op het loon als op werkgelegenheid, hebben hoogopgeleiden alleen op het loon ingeleverd. Bovendien is het loon voor hoogopgeleiden veel minder hard gedaald. De daling van de werkloosheid sinds 2013 en de toenemende krapte op de arbeidsmarkt gingen echter niet eenduidig gepaard met een stijging van de lonen. De lonen van laagopgeleiden dalen in reële termen. De lonen van hoogopgeleiden stijgen licht. De achterblijvende loonontwikkeling, vooral voor laagopgeleiden, is waarschijnlijk het gevolg van een lagere groei van de arbeidsproductiviteit. 



\section{DOEL EN OPZET}

Doel

Als onderdeel van het Project Onderwijs-Arbeidsmarkt $(P O A)^{1}$ ontwikkelt het Researchcentrum voor Onderwijs en Arbeidsmarkt (ROA) een aantal activiteiten gericht op het inzichtelijker maken van ontwikkelingen in vraag en aanbod op de arbeidsmarkt, het analyseren van de aansluiting tussen de vraag naar en het aanbod van arbeid, het ontwikkelen van arbeidsmarktindicatoren voor de actuele aansluiting tussen vraag en aanbod, en de ontwikkeling van arbeidsmarktprognoses naar bedrijfssectoren, beroepen, opleidingen en regio's. Deze rapportage is een weergave van de uitkomsten van de analyses in het POA. Hierin wordt een overzicht gepresenteerd en besproken van de huidige en verwachte ontwikkelingen op de Nederlandse arbeidsmarkt tot 2024.

De arbeidsmarktinformatie die ontwikkeld is als onderdeel van POA is relevant voor verschillende doelgroepen. Een belangrijke doelgroep van de arbeidsmarktinformatie wordt gevormd door jongeren en werkzoekenden die voor de keuze van een (vervolg) opleiding staan. De gegevens stellen hen in staat hun keuze te baseren op de arbeidsmarktperspectieven die de verschillende opleidingen bieden op de middellange termijn. Verschillende websites (www.studiekeuze123.nl) en keuzegidsen voor het onderwijs (www.keuzegids.org) dragen bij aan de verspreiding van de gegevens onder deze doelgroep. Deze voorlichtingsfunctie wordt verder vervuld via verschillende zelfstandige organisaties in het onderwijsveld, waaronder SBB (www.kansopwerk.nl) die cijfers uit POA betrekken in hun informatievoorziening. Onderzoek laat zien dat jongeren veel baat hebben bij een transparante arbeidsmarkt. ${ }^{2}$ Ook werkgevers, arbeidsbemiddelaars en beleidsmakers kunnen hier veel baat bij hebben. Werkgevers kunnen bij een voorspelde disbalans tussen vraag en aanbod hun wervingsstrategie en arbeidsvoorwaarden aanpassen. Arbeidsbemiddelaars en uitkeringsinstanties kunnen hun toeleidings- en bijscholingstrajecten bijstellen (Randstad en UWV gebruiken de ROA-prognoses voor eigen studies). Beleidsmakers kunnen beleid inzetten om ervoor te zorgen dat toekomstige personeelstekorten in bijvoorbeeld de techniek of het onderwijs minder groot

1 Dit rapport is tot stand gekomen mede dankzij financiering van NRO (dossiernummer 405-17900), UWV, SBB en Randstad. Zie de website voor meer informatie en andere output van het POA: https://roa.maastrichtuniversity.nl/research/research-projects/project-onderwijs-arbeidsmarkt-poa

2 Fouarge, D. (2017). Veranderingen in werk en vaardigheden. Oratie, Maastricht University; Fouarge, D., A. KünnNelen \& A. Mommers (2016). Studiekeuze en arbeidsmarkt: literatuurstudie. Maastricht: ROA-R-2016/3 
worden dan verwacht door de keuze voor deze opleidingen te stimuleren. Sinds 2016 gebruikt de Commissie Doelmatigheid Hoger Onderwijs (CDHO) de ROA-prognoses voor de beoordeling van doelmatigheidsdossiers. Ten slotte zijn de prognoses bedoeld voor het arbeidsmarktbeleid in ruime zin. Daarbij kan gedacht worden aan onder andere het doelgroepenbeleid, het beleid gericht op het vergroten van de arbeidsmarktparticipatie en het arbeidsmarktbeleid ten aanzien van de onderkant van de arbeidsmarkt. Het POA is dus een basisvoorziening ten behoeve van het algemene belang voor de hele breedte van het onderwijsveld en het beroepenspectrum van de arbeidsmarkt. ${ }^{3}$ Het project geniet van internationale bekendheid. Vaak worden buitenlandse delegaties volledig voorgelicht over het prognosemodel en de toepassing en het gebruik ervan. ${ }^{4}$

Het presenteren van prognoses gaat altijd met enige onzekerheid gepaard 5 en de hier gepresenteerde ramingen zullen daardoor enigszins afwijken van uiteindelijke realisaties. Desalniettemin zijn de in dit rapport gepresenteerde prognoses, die gebaseerd zijn op een gestructureerde modelmatige aanpak van de uitbreidingsvraag, vervangingsvraag en instroom op de arbeidsmarkt, waardevol voor degenen die keuzes moeten maken voor de toekomst. Het nut van de prognoses ligt in het feit dat deze structurele informatie verschaffen betreffende de te verwachten discrepantie tussen vraag en aanbod en daarmee gepaard gaande spanningen op de arbeidsmarkt, waarbij expliciet rekening wordt gehouden met interacties en aanpassingsprocessen tussen deelmarkten.

De verzameling van indicatoren voor de actuele arbeidsmarktsituatie en de middellange termijn prognoses waarop dit rapport zich baseert, zijn geïntegreerd in een online database: het ArbeidsmarktInformatieSysteem (AIS). ${ }^{6}$ Gegevens over de actuele arbeidsmarktsituatie worden jaarlijks geactualiseerd, en dit geldt ook sinds 2018 voor de prognoses.? De prognoses hebben betrekking op een periode van zes jaar. Dit rapport beperkt zich tot een bespreking van ontwikkelingen voor grotere aggregaten van beroepen en opleidingen. Gedetailleerde informatie voor specifieke opleidingstypes en beroepsgroepen, evenals de regionale prognoses, zijn in het AIS te vinden.

\section{Prognosemodel}

ROA gaat uit van een stroomcijfer-aanpak bij het doorrekenen van de arbeidsmarktprognoses. Bij deze aanpak worden prognoses gemaakt van de stromen van en naar de arbeidsmarkt in een bepaalde toekomstige periode. Er wordt gekozen voor een periode van zes jaar vooruit omdat dit ongeveer overeenkomt met de tijd tussen de eerste stappen op de arbeidsmarkt. Hierbij worden gegevens gebruikt over de trendmatige

3 Voor een overzicht van de doelgroepen en het gebruik van POA, zie: Fouarge, D. (2015). Project OnderwijsArbeidsmarkt: Gebruik van arbeidsmarktinformatie en impact. ROA, Maastricht: ROA-TR-2015/4.

4 Als onderdeel van een internationaal consortium onder leiding van Cambridge Econometrics werkt ROA samen met internationale partners aan de Cedefop 'skills supply and demand forecast'.

5 De prognoses zijn gemaakt in de zomer van 2019, en zodoende wordt er geen rekening gehouden in de prognoses met meer recente economische ontwikkelingen omtrent bijvoorbeeld de Brexit of het stikstofbeleid.

6 Zie http://roastatistics.maastrichtuniversity.nl/Een overzicht van de verkrijgbare arbeidsmarktinformatie per bedrijfssector, beroepsgroep en opleidingstype is te vinden in bijlage $C$.

7 Bakens, J., Dijksman, S., \& Fouarge, D. (2018). Actualisering AIS en ROA prognoses tot 2022. Maastricht: ROA-F2018/19. 
ontwikkelingen van de werkgelegenheid in het verleden per bedrijfssector, beroep en opleiding. ${ }^{8}$ De prognoses tot en met 2024 zijn gebaseerd op de ontwikkelingen op de arbeidsmarkt in het aantal werkenden naar sector, beroep, en opleiding tussen 1996 en 2018. Eigen (verklarende) econometrische modellen vormen de structuur van het prognosemodel. De belangrijkste bronnen voor de inputdata van het prognosemodel zijn: i) cijfers uit de Enquête Beroepsbevolking (EBB) van Centraal Bureau voor de Statistiek (CBS), ii) prognoses over de toekomstige ontwikkelingen in de werkgelegenheid per bedrijfssector, iii) referentieramingen van het Ministerie van Onderwijs, Cultuur en Wetenschap, en iv) data uit het ROA SchoolverlatersInformatieSysteem (SIS).

Deze benadering heeft als voordeel dat de processen in kaart worden gebracht die van belang zijn voor de ontwikkeling van zowel vraag als aanbod op de arbeidsmarkt. De arbeidsmarkt wordt dus in zijn integraliteit in beschouwing genomen. Dit verdient de voorkeur boven een alternatieve aanpak waarbij deelmarkten apart worden onderzocht omdat het meer recht doet aan de substitutiemogelijkheden tussen deelmarkten op de arbeidsmarkt die door ROA expliciet worden gemodelleerd. ${ }^{9}$ Daar waar werkenden steeds vaker van baan verwisselen tussen verschillende sectoren en tussen verschillende beroepen, en om- en bijscholing steeds belangrijker worden, is een integrale analyse van de arbeidsmarkt voor het maken van arbeidsmarktprognoses cruciaal. Zoals het Centraal Planbureau (CPB) het heeft geformuleerd: "Ramingen die niet al te ver vooruitgaan, zoals de ramingen naar sector en opleiding van het ROA [...], zijn zinvol omdat ze de markt van informatie voorzien. Daarnaast houden de ramingen van het ROA wel rekening met de wisselwerking tussen deelmarkten."10

De arbeidsmarktprognoses worden doorgerekend voor in totaal 113 beroepsgroepen en 108 opleidingstypen," gespreid over de volledige breedte van de arbeidsmarkt."2 Daarnaast worden de prognoses doorgerekend voor 35 arbeidsmarktregio's. De prognoses naar arbeidsmarktregio worden opgenomen in het AIS en de methodiek en uitkomsten worden in een aparte publicatie opgenomen. Van belang is dat de prognoses, en ook de overige opgenomen arbeidsmarktgegevens, in dit rapport hoofdzakelijk worden gepubliceerd op het niveau van 13 beroepsklassen en 33 opleidingssubsectoren. ${ }^{33}$ De onderliggende beroepsgroepen en opleidingstypen alsook de gehanteerde indeling voor bedrijfssectoren zijn opgenomen in Bijlage B van dit rapport. Bij de doorrekening van het prognosemodel is uitgegaan van werkenden volgens de internationale ILO-definitie, waarbij alle banen van 1 uur of meer worden meegeteld van personen in de leeftijd 15-74 jaar. ${ }^{14}$

8 Zie bijlage A voor een overzicht van de centrale begrippen bij de arbeidsmarktprognoses.

9 Partiële prognoses kunnen overigens complementair zijn omdat zij voorzien in informatiebehoefte vanuit specifieke markten. Echter, partiële prognoses nemen de wisselwerking tussen deelmarkten niet mee.

10 CPB (2013), Economische analyse van korte en lange termijn knelpunten op de arbeidsmarkt, Den Haag: CPB Notitie, 31 mei 2013.

11 Vanaf dit jaar wordt met een nieuwe opleidingsclassificatie, de ONR2019, gewerkt. Bakens, J., Dijksman, S., Fouarge, D. (2019) Opleidingsclassificatie naar Niveau en Richting 2019: Achtergronddocumentatie. Maastricht: ROA-TR-2019/1.

12 Er wordt in het prognosemodel gerekend met in totaal 114 beroepsgroepen en 108 opleidingstypen. Dit is inclusief de categorieën 'overige beroepen' en overige opleidingen op alle niveaus.

13 Inclusief de categorieën 'overig' gaat het om 47 opleidingscategorieën, maar de prognoses voor basisonderwijs en vmbo (inclusief mbo, niveau 1), en havo/vwo worden alleen besproken in hoofdstuk 1.

14 Bijlsma, I. S. Dijksman, D. Fouarge, A. Künn-Nelen \& D. Poulissen (2015). Veranderingen in de omvang en samenstelling van de beroepsbevolking als gevolg van de overstap op de ILO-definitie van de beroepsbevolking. Maastricht: ROA-TR-2015/6. 
Figuur 1 geeft een schematisch overzicht van het prognosemodel. ${ }^{15}$ Globaal gezien gaat het er om dat spanningsindicatoren voor de vraag-aanbodverhouding (in stippellijnen weergegeven) worden afgeleid van schattingen van de toekomstige vraag naar arbeid en het te verwachten aanbod van arbeid.

\section{FIGUUR 1 Schematisch opzet prognosemodel}

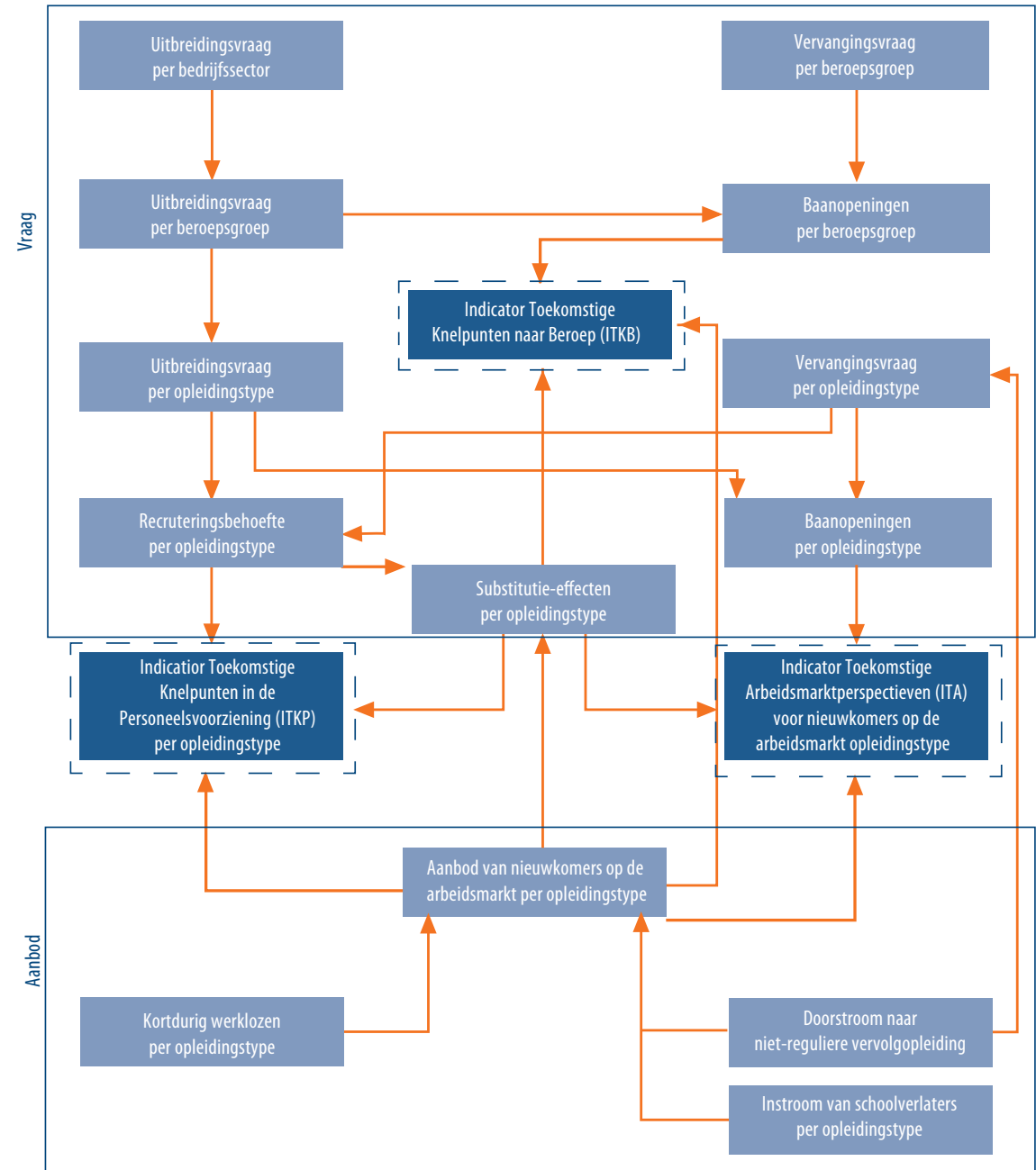

Spanningsindicator

15 De gebruikte methodiek zal binnenkort verschijnen. De details van de laatst gebruikte methodiek zijn hier te vinden: Bakens, J., Bijlsma, I., Cörvers, F., Dijksman, S., Fouarge, D., \& Poulissen, D. (2018). Methodiek arbeidsmarktprognoses en -indicatoren 2017-2022. Maastricht: ROA-TR-2018/4. Zie bijlage A voor een verdere uitleg van de begrippen en verwijzingen naar de verschillende onderzoeken die door het ROA zijn uitgevoerd in het kader van de modelbouw. 


\section{Vraag naar arbeid}

Een stroomgrootheid die van belang is voor de vraagzijde van de arbeidsmarkt is de uitbreidingsvraag, die de te verwachte ontwikkeling weergeeft van de werkgelegenheid in een bepaalde beroepsgroep of een bepaald opleidingstype. Voor de berekening van de uitbreidingsvraag naar beroep en opleiding zijn de macro-economische en sectorale ontwikkelingen van groot belang. Hiervoor wordt aangesloten bij de ramingen over de economische groei, de werkgelegenheid en de participatiegraden van het CPB. Voor het samenstellen van de arbeidsmarktprognoses in dit rapport is gebruik gemaakt van ramingen uit het Centraal Economisch Plan (CEP) 2019. ${ }^{16}$ Voor 2019 en 2020 wordt uitgegaan vaan een economische groei van 1,5\%, wat dicht ligt bij de langetermijntrend. Verder wordt er in dit rapport uitgegaan van een gemiddelde werkgelegenheidsgroei van 0,9\% per jaar tot en met 2024. Echter, voor 2019 en 2020 wordt nog een werkgelegenheidsgroei van, respectievelijk, $1,5 \%$ en $1,2 \%$ verwacht, om daarna terug te zakken naar $0,6 \%$ per jaar.

De CPB macro-economische ramingen zijn door SEOR op verzoek van het ROA gedifferentieerd naar 21 bedrijfssectoren. ${ }^{17}$ Het gaat hierbij om prognoses voor de ontwikkeling van de werkenden en banen, alsook van de toegevoegde waarde en de investeringen in kapitaal die gebruikt worden bij de schatting van de uitbreidingsvraag naar beroep. Er is zoveel mogelijk uitgegaan van het macro-economische kader van het CPB en de bevolkingsprognoses van het CBS. Deze sectorprognoses worden ook gebruikt door het UWV waardoor ROA- en UWV-cijfers goed te vergelijken zijn.. ${ }^{18}$

Uitgaand van de verwachte uitbreidingsvraag naar bedrijfssectoren worden ten eerste door het ROA prognoses gemaakt van de verschuivingen in de beroepenstructuur binnen de onderscheiden bedrijfssectoren. ${ }^{19}$ Hierdoor kan er rekening gehouden worden met het feit dat binnen een bedrijfssector bepaalde beroepsgroepen zich sneller ontwikkelen dan andere, bijvoorbeeld als gevolg van veranderingen in taken en productieprocessen, technologische ontwikkelingen of internationalisering in een sector. Voorts zijn er in het zogenaamde beroepenmodel van de uitbreidingsvraag, naast de ontwikkeling van de omvang en structuur van de werkgelegenheid, verschillende verklarende variabelen (toegevoegde waarde en investeringen) gebruikt om de prognoses van de uitbreidingsvraag naar beroep samen te stellen. ${ }^{20}$ Ten tweede wordt bepaald welke implicaties de geprognostiseerde groei van de verschillende beroepsgroepen heeft voor de uitbrei-

16 CPB (2019). Centraal Economisch Plan 2019. Den Haag. https://www.cpb.nl/sites/default/files/omnidownload/Centraal-Economisch-Plan-CEP-2019.pdf

De sectorale afbakening wordt gepresenteerd in bijlage $B$

18 UWV (2019). UWV Arbeidsmarktprognose 2019-2020: https://www.uwv.nl/overuwv/kennis-cijfers-enonderzoek/arbeidsmarktinformatie/uwv-arbeidsmarktprognose-2019-2020.aspx De sectorale prognoses die ROA nu gebruikt voor haar arbeidsmarktprognosemodellen werden voorheen aangeleverd door een ander bureau die een andere methodiek gebruikte. Hierdoor, maar ook omdat de economische verwachtingen anders uitpakken, zijn de in dit rapport gepresenteerde sectorale prognoses niet goed te vergelijkbaar met die uit vorige prognoses.

19 Dit gebeurt aan de hand van allocatiematrices van beroep naar bedrijfssector voor de periode 1996-2018.

20 F. Cörvers en A. Dupuy (2010), Estimating employment dynamics across occupations and sectors of industry, Journal of Macroeconomics, 32: 17-27. 
dingsvraag per opleidingstype. Hierbij wordt rekening gehouden met het optreden van verschuivingen in de samenstelling van opleidingen binnen beroepsgroepen. Dit is van belang om rekening te kunnen houden met de skill upgrading ${ }^{21}$ en veranderende vraag naar vaardigheden binnen beroepen. ${ }^{22}$ De uitbreidingsvraag per opleidingstype heeft betrekking op het aantal personen met een bepaalde opleidingsachtergrond die werkgevers zouden willen aannemen om te kunnen voorzien in een grotere vraag naar goederen en diensten. Gediplomeerden die overwegend werkzaam zijn in krimpberoepen kunnen met een negatieve uitbreidingsvraag te maken hebben. De feitelijke ontwikkeling van het aantal werkenden per opleidingstype zal hier doorgaans van afwijken door de interactie met de aanbodzijde van de arbeidsmarkt, en de als gevolg daarvan optredende substitutieprocessen. ${ }^{23}$ Bij de analyse van de werkgelegenheidsontwikkeling naar sector, beroep en opleiding wordt intensief gebruik gemaakt van de EBB van het CBS (jaren 1996-2018).

Naast uitbreidingsvraag is er op de arbeidsmarkt sprake van vervangingsvraag door - al dan niet vervroegde - pensionering, arbeidsongeschiktheid, tijdelijke terugtreding van de arbeidsmarkt, beroepsmobiliteit, e.d. Om de uitstroom te bepalen worden veronderstellingen gemaakt ten aanzien van de participatiegraden in de verschillende leeftijdscohorten. Hiervoor is uitgegaan van de meest recente CPB-prognoses van de bruto participatiegraden per leeftijd en geslacht. ${ }^{24}$ Sinds enkele jaren houdt deze module rekening met skills-upgrading in de vervangingsvraag..$^{25}$ Van vervangingsvraag is enkel sprake als het vertrek van een werkende in een beroep of met een specifieke opleidingsachtergrond ook daadwerkelijk leidt tot vraag naar een andere werkende. Als werkgelegenheidskrimp de reden is voor vertrek, dan is er in het model geen sprake van vervangingsvraag omdat deze uitstroom niet relevant is voor nieuwkomers (het leidt niet tot een baanopening). Dit betekent dus dat niet de volledige arbeidsmarktuitstroom daadwerkelijk leidt tot vervangingsvraag.

De vervangingsvraag wordt afzonderlijk voor beroepsgroepen en opleidingstypen berekend. De vervangingsvraag naar beroep kan om verschillende redenen afwijken van de vervangingsvraag naar opleiding. Zo is de mobiliteit tussen beroepsgroepen wel van invloed op de vervangingsvraag per beroepsgroep, maar heeft deze geen effect op de vervangingsvraag per opleidingstype. De mobiliteit tussen beroepsgroepen heeft tenslotte geen directe gevolgen voor de opleidingsstructuur van de werkgelegenheid, hoewel ze hiermee wel kunnen samenvallen. Daar staat tegenover dat het afronden van een vervolgopleiding gelijk staat aan uitstroom naar een ander (doorgaans hoger) opleidingstype. In dat geval is er sprake van een vervangingsvraag bij het opleidings-

21 A. Dupuy (2006), Measuring Skill-upgrading in the Dutch Labor Market, ROA-W-2006/3E, Maastricht: ROA.

22 Fouarge, D. (2017). Veranderingen in de vraag naar vaardigheden. Tijdschrift voor het Economisch Onderwijs, 114 (6), 18-21; Berg, E. van den, Eldert, P. van, Fouarge, D., \& Weel, B. ter (2018). Taken en vaardigheden op het werk. Bevindingen uit de eerste en tweede Nederlandse Skills survey. Maastricht: ROA-R-2018/6.

23 F. Cörvers en H. Heijke (2004), Forecasting the labour market by occupation and education: Some key issues, ROA-W-2004/4, Maastricht: ROA.

24 De participatiegraden zijn aan ons beschikbaar gesteld door het CPB.

25 Zie voor een verantwoording hoofdstuk 4 in ROA (2015). De arbeidsmarkt naar opleiding en beroep tot 2020. Maastricht: ROA-R-2015/6. 
type waartoe de vooropleiding van deze werkende wordt gerekend. Maar deze vervangingsvraag heeft geen gevolgen voor de beroepenstructuur. Uitstroompatronen naar beroep en opleiding worden geschat aan de hand van de EBB, waarbij alleen data voor de meest recente 10 jaar worden gebruikt. Dit doen wij omdat het recente verleden een betere weerspiegeling van de feitelijke opleidingseisen en vraag naar vaardigheden is dan wanneer wij zouden uitgaan van de data uit het verdere verleden. Bij een toename van de werkgelegenheid vormen de uitbreidingsvraag en de vervangingsvraag samen de baanopeningen voor nieuwkomers op de arbeidsmarkt. Bij krimpende werkgelegenheid leidt alleen de vervangingsvraag tot baanopeningen.

\section{Aanbod van arbeid}

Tegenover de totale vraag naar nieuwkomers staat het verwachte aanbod van nieuwkomers op de arbeidsmarkt. Ten eerste bestaat het aanbod uit de toekomstige arbeidsmarktinstroom van gediplomeerden en de doorstroom naar een ander opleidingstype vanwege het afronden van post-initiële vervolgopleidingen in de prognoseperiode. De tweede component van het arbeidsaanbod bestaat uit het nog boven de markt zwevende aanbod van kortdurig werklozen aan het begin van de prognoseperiode. Hierbij wordt verondersteld dat langdurig werklozen (die langer dan een jaar op zoek zijn naar werk) geen serieuze concurrenten meer vormen voor gediplomeerden. ${ }^{26}$

De instroomprognoses van gediplomeerden op de arbeidsmarkt hebben de Referentieraming 2019 van het Ministerie van Onderwijs, Cultuur en Wetenschap als uitgangspunt. ${ }^{27}$ Deze prognoses hebben betrekking op de verwachte uitstroom uit het initiële onderwijs. Deze prognoses worden door het ROA verbijzonderd en aangevuld met prognoses van de doorstroom naar het post-initiële onderwijs, op basis van gegevens uit de Onderwijsmatrix, de Enquête Beroepsbevolking van het CBS en gegevens uit het Schoolverlatersinformatiesysteem (SIS) van het ROA.

\section{Spanningsindicatoren}

De verwachte vraag- en aanbodstromen per opleidingstype worden met elkaar geconfronteerd om een indicatie te krijgen van de toekomstige arbeidsmarktperspectieven voor nieuwkomers op de arbeidsmarkt. Deze Indicator Toekomstig Arbeidsmarktperspectieven (ITA) geeft aan welke vraag-aanbod-discrepantie er per opleidingstype te verwachten is in de komende zes jaar. Als het arbeidsaanbod kleiner is dan de vraag, en de ITA dus kleiner dan of gelijk is aan 1,00, wordt het arbeidsmarktperspectief als 'goed' getypeerd. Als de waarde van de ITA kleiner dan of gelijk is aan 0,85 , wordt gesproken van een

26 Het CPB concludeert dat de werkloosheidsduur negatief samenhangt met de relevantie van de groep voor het bepalen van het evenwicht op de arbeidsmarkt (M. de Graaf-Zijl, A. van der Horst, D. van Vuuren, 2015, Langdurige werkloosheid. Afwachten en hervormen. CPB Policy Brief 2015/11).

27 https://www.rijksoverheid.nl/documenten/rapporten/2019/og/17/referentieraming-ocw-2019 
'zeer goed' arbeidsmarktperspectief. ${ }^{28}$ Daarentegen, als de ITA een waarde heeft tussen de 1,00 en 1,05 - en het aanbodoverschot dus niet veel groter is dan wat als frictie kan worden beschouwd - wordt gesproken van een 'redelijk' arbeidsmarktperspectief. Bij een hogere waarde van de ITA wordt het arbeidsmarktperspectief voor het desbetreffende opleidingstype als 'matig', of bij een ITA groter dan 1,15, als 'slecht' aangeduid. ${ }^{29}$

Het is belangrijk om stil te staan bij de interpretatie van deze spanningsindicator. Een aanbodoverschot impliceert niet vanzelfsprekend dat de desbetreffende groep werkloos zal worden en een aanbodtekort betekent niet automatisch dat er sprake zal zijn van onvervulde vacatures. Het is immers ook mogelijk dat werkgevers hun eisen aanpassen en mensen aannemen met een andere opleidingsachtergrond dan aanvankelijk gevraagd werd. Gediplomeerden met een opleiding waarvoor het aanbod de vraag overtreft ervaren in een dergelijke situatie een verslechtering van hun positie doordat zij bijvoorbeeld vaker beneden hun niveau of buiten hun richting moeten werken, slechter beloond worden of vaker genoegen moeten nemen met deeltijdwerk, terwijl men liever een voltijdsbetrekking had. ${ }^{30}$ Omgekeerd zal bij een tekortschietend aanbod de positie van gediplomeerden verbeteren. Deze hoeven in dat geval minder vaak genoegen te nemen met een functie op een lager niveau, een lagere beloning e.d. Bij de opleidingen die door opleidingstypen met een aanbodoverschot worden verdrongen, zal het aantal baanopeningen vanwege dit substitutieproces kleiner worden. Daarentegen zal er voor de opleidingen die verwant zijn aan de opleidingen met een tekortschietend aanbod juist sprake zijn van extra baanopeningen. Wanneer er sprake is van knelpunten zullen deze substitutie-effecten derhalve van belang zijn voor de arbeidsmarktperspectieven van de desbetreffende opleidingen.

De vraag-aanbod-confrontatie geeft voor elk opleidingstype ook een indicatie van de toekomstige knelpunten in de personeelsvoorziening die relevant is voor werkgevers. Daarbij bepalen de uitbreidings- en vervangingsvraag samen de recruteringsbehoefte per opleidingstype. Bij krimpende werkgelegenheid voor een bepaald opleidingstype wordt deze recruteringsbehoefte op een andere wijze berekend dan het aantal baanopeningen voor nieuwkomers op de arbeidsmarkt. In dat geval bestaat immers vanuit het perspectief van bedrijven de mogelijkheid om de gedwongen uitstroom van het zittende personeel (negatieve uitbreidingsvraag per opleiding) te verminderen. Zeker

28 Deze grenzen voor de ITA zijn gebaseerd op een statistische analyse van de spreiding van de arbeidsmarktsituatie van de verschillende opleidingstypen. Zie M. Wieling, A. de Grip en E. Willems (1990), Een systematische kwalitatieve typering van arbeidsmarktinformatie, ROA-W-1990/8, Maastricht: ROA. Zie voor een analyse van de betekenis van de ITA ook A. Dupuy (2009), An evaluation of the forecast of the indicator of the labour market gap, ROA-TR-2009/3, Maastricht: ROA.

29 ROA evalueert geregeld de kwaliteit van de prognoses. Zie bijvoorbeeld voor de vervangingsvraag $\mathrm{R}$. Montizaan (2009), Evaluatie vervangingsvraagprognoses naar opleiding en beroep, ROA-TR-2009/1, Maastricht: ROA. Uit de evaluatie van voorgaande prognoses blijkt dat voor ruim $40 \%$ van de opleidingstypen de juiste van de vijf mogelijke typeringen werd gegeven. Voor ca. $80 \%$ van de opleidingstypen werd de juiste of een aangrenzende typering voorspeld. Zie A. Dupuy (2009), An evaluation of the forecast of the indicator of the labour market gap, ROA-TR-2009/3, Maastricht: ROA; D. Bertrand-Cloodt (2010), Evaluatie uitbreidingsvraag en indicator toekomstig arbeidsmarktperspectief (ITA) tot 2008, ROA-TR-2010/6, Maastricht: ROA

30 M. Wieling en L. Borghans (2001), Discrepancies between supply and demand and adjustment processes in the labour market, Labour, 15: 33-56. 
wanneer bedrijven geconfronteerd worden met een krappe arbeidsmarkt voor een bepaald opleidingstype, mag worden aangenomen dat zij van deze mogelijkheid gebruik zullen maken. De te verwachten spanning in personeelsvoorziening komt tot uiting in de Indicator Toekomstige Knelpunten in de Personeelsvoorziening (ITKP). Omdat er voor de meeste bedrijfssectoren sprake is van groei en werkenden met verschillende opleidingsachtergrond werk vinden in een groot scala aan beroepen is er nauwelijks sprake van negatieve uitbreidingsvraag per opleidingstype en zijn de ITA en ITKP tot 2024 vrijwel aan elkaar gelijk. Om die reden wordt de ITKP in dit rapport niet gepresenteerd.

De aansluitingsproblematiek tussen onderwijs en arbeidsmarkt verbijzonderd naar de onderscheiden opleidingstypen staat in dit rapport centraal. In aanvulling daarop wordt inzicht gegeven in de implicaties die de vraag-aanbodverhoudingen voor de onderscheiden opleidingstypen hebben voor de knelpunten in de personeelsvoorziening per beroepsgroep. De Indicator Toekomstige Knelpunten in de Personeelsvoorziening naar Beroep (ITKB) reflecteert de verwachte spanning naar beroep. De ITKB geeft de kans weer dat de gewenste personeelssamenstelling naar opleiding binnen beroepsgroepen gerealiseerd kan worden, rekening houdend met het verwachte aanbod per opleiding. Bij de berekening van de ITKB wordt rekening gehouden met het verwachte aanbod van scholieren met bijbanen. Dit is noodzakelijk bij gebruik van de internationale definitie van arbeid. Door deze definitie telt de beroepsbevolking veel kleine banen van jongeren die nog niet in de instroom zijn verdisconteerd, maar wel een bijbaan hebben als scholier. ${ }^{31}$ Wanneer hier geen rekening mee wordt gehouden, worden de knelpunten overschat in beroepen waar veel gebruik wordt gemaakt van scholieren en waar personeelsroulatie groot is (bijvoorbeeld vakkenvullers).

Inzicht in de knelpunten naar beroepsgroep is voor verschillende gebruikers en gebruiksdoelen relevant. In de eerste plaats kan inzicht in de knelpunten naar beroepsgroep van belang zijn voor werkgevers bij hun wervings- en personeelsbeleid. Op de tweede plaats kunnen (langdurig) werklozen of werkenden die op zoek zijn naar een andere werkkring gebruik maken van de informatie in hun oriëntatie naar een nieuwe of andere werkkring. Nauw met dit tweede gebruiksdoel samenhangend zijn de bij- en omscholingsprogramma's die doorgaans gericht zijn op een bepaalde beroepsgroep. Inzicht in de knelpunten naar beroep kan derhalve een leidraad zijn bij het opzetten van dergelijke scholingsprogramma's.

31 I. Bijlsma, S. Dijksman, D. Fouarge, A. Künn-Nelen \& D. Poulissen (2015), Veranderingen in de omvang en samenstelling van de beroepsbevolking als gevolg van de overstap op de ILO-definitie van de beroepsbevolking, Maastricht: ROA-TR-2015/6. 
In het wetenschappelijke debat ${ }^{32}$ en in beleidsdiscussies ${ }^{33}$ is veel nadruk gelegd op de rol van automatisering en robotisering als verklaring voor veranderingen in de werkgelegenheidsstructuur: banen met overwegend routinematige taken (denk hierbij aan de bankbediende en de secretaresse) die efficiënter uitgevoerd kunnen worden met behulp van nieuwe technologieën zouden onder druk komen te staan. De vraag is dan in welke mate het prognosemodel dit soort mechanismen goed oppakt. Wij vinden een negatieve correlatie tussen de uitbreidingsvraag in beroepen en het automatiseringsrisico in die beroepen, waarbij het automatiseringsrisico, dat niet expliciet is gemodelleerd in het ROA prognosemodel, afkomstig is van Deloitte. ${ }^{34}$ Tevens laat figuur 2 de relatie zien tussen de verwachte knelpunten naar beroepen en het automatiseringsrisico in die beroepen, ${ }^{35}$ waarbij de grootte van de rondjes evenredig is aan het aantal werkenden. De figuur laat een duidelijk verband zien tussen beide: de knelpunten naar beroep worden kleiner naarmate het automatiseringsrisico groter is. Tevens vinden wij aan de hand van de Nederlandse Skills Survey dat er meer knelpuntenpunten zijn in beroepen naarmate de complexiteit van het werk in beroepen groter is.

\section{FIGUUR 2 Relatie tussen verwachte knelpunten tot en met 2024 en automatiseringskans naar beroep}

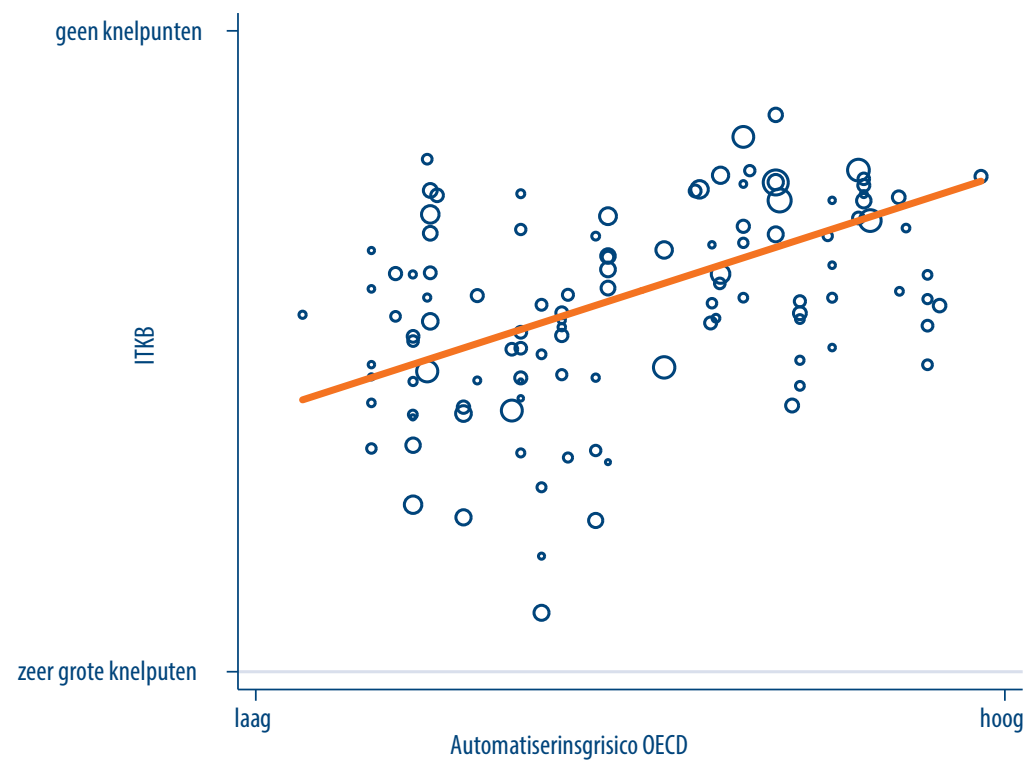

Bron: ROA (AIS), Deloitte

32 Frey, C., \& Osborne, M. (2017). The future of employment: how susceptible are jobs to computerisation? Technological Forecasting and Social Change, 114, 254-280.

33 SER (2016). Mens en technologie: Samen aan het werk. SER: Den Haag.

34 Deloitte (2014). De impact van automatisering op de Nederlandse arbeidsmarkt. Een gedegen verkenning op basis van Data Analytics. Deloitte

35 Het automatiseringsrisico, dat niet expliciet is gemodelleerd in het ROA prognosemodel, is afkomstig van Deloitte (2014). De impact van automatisering op de Nederlandse arbeidsmarkt. Een gedegen verkenning op basis van Data Analytics. Deloitte. 
De totale verwachte vraag in de prognoseperiode in het betreffende beroep wordt in dit rapport gerelateerd aan enerzijds de wijze waarop werkgevers de vraag beogen in te vullen qua opleidingsachtergrond van de arbeidskrachten en anderzijds de vraagaanbodverhoudingen voor de voor dat beroep relevante opleidingstypen. Hierdoor wordt een indicatie verkregen van de problemen die werkgevers bij het werven van personeel zullen ondervinden. Wanneer voor een bepaald beroep kennis en vaardigheden vereist zijn die met name aanwezig zijn bij mensen met een opleidingsachtergrond waarvoor grote tekorten worden verwacht, zullen werkgevers veel moeite hebben personeel te vinden dat over de voor dat beroep vereiste kwalificaties beschikt. Wanneer het hier over zeer beroepsspecifieke expertise gaat, zullen de knelpunten extra groot zijn, aangezien er in dat geval weinig alternatieven voorhanden zijn. Wanneer het daarentegen meer algemene competenties betreft, kan de werkgever doorgaans mensen met een andere opleidingsachtergrond aantrekken. De werkgever heeft dan meer substitutiemogelijkheden tussen opleidingen.

\section{TEKSTBOX Arbeidsmarktinformatie en studiekeuze}

Onderzoek laat zien dat een niet-geanticipeerde stijging van het werkloosheidspercentage voor een studierichting positief samenhangt met de mate waarin gediplomeerden spijt hebben van hun studiekeuze. ${ }^{36}$ Dit suggereert dat het geven van informatie over toekomstige verwachte ontwikkelingen op de arbeidsmarkt de match tussen vraag en aanbod zou kunnen verbeteren. Het is zeker niet zo dat het studiekeuzeproces altijd het resultaat is van een rationele overweging die jongeren maken ten aanzien van wat zij met hun opleiding kunnen bereiken in termen van banen en loon. De sociale context, de eigen preferenties voor bepaalde richtingen in het onderwijs en beroepen en verwachtingen met betrekking wat men cognitief 'aankan', spelen een belangrijke rol in de studie- en beroepskeuze. ${ }^{37}$ In een aan POA gerelateerd onderzoek onder mbo'ers laten wij inderdaad zien dat arbeidsmarktperspectieven van opleidingen beslist niet het eerste zijn waar jongeren naar kijken bij het maken van hun opleidingskeuze..$^{38}$ Echter, het onderzoek laat aan de hand van een vignetexperiment zien dat 1) jongeren gevoelig zijn voor de verwachte arbeidsmarktperspectieven van opleidingen bij het maken van hun keuze, 2) het signaal dat een opleiding 'slecht'scoort in termen van arbeidsmarktkansen een groot effect heeft op het niet kiezen voor de opleiding, en 3) dat studiekiezers bereid zouden zijn te kiezen voor een opleiding die minder bij hun interesses past als de arbeidsmarktkansen voor die opleiding beter zijn dan die van de opleiding die het beste past bij hun interesses. In een veldexperiment waarin wij op gerandomiseerde wijze informatie over de arbeidsmarktkansen van beroepen aan vmbo'ers tonen, laten wij zien dat 1) vmbo'ers de baankansen en loon van beroepen die zij leuk vinden overschatten, 2) het geven van informatie over baankans en loon de verkeerde verwachtingen helpt te corrigeren en 3) wanneer vmbo'ers informatie hebben gekregen over de feitelijke baankans en loon van de beroepen die zij leuk vinden, zij vaker de beroepen met de beste baankans en loon op plek één zetten van geprefereerde beroepen. ${ }^{39}$

36 Somers, M. en D. Fouarge (2019). The role of unanticipated labour market conditions in graduates' regret of study choice. Paper for the 2nd BIBB Conference 'The Economics of Vocational Education and Training', Siegburg, 7/8 November 2019.

37 Fouarge, D., A. Künn-Nelen \& A. Mommers (2016), Studiekeuze en arbeidsmarkt: literatuurstudie, Maastricht: ROA-R-2016/3.

38 Fouarge, D., Künn, A., Punt, D. (2017), De rol van arbeidsmarktinformatie in de opleidingskeuze van mbo'ers, Maastricht: ROA-R-2017/9.

39 Koning, B. de, R. Dur, D. Fouarge (2019). Correcting Erroneous Beliefs about Job Opportunities and Wages: A Field Experiment on Education Choices, Workshop Improving Quality and Returns to Education, Leuven, 15 November 2019. 
In veel gevallen wordt in dit rapport, naast een getalsmatige indicatie, een kwalitatieve typering gegeven van de prognose. Het doel van deze kwalitatieve typeringen is drieledig. Ten eerste, vereenvoudigt de typering de interpretatie van de cijfers. Ten tweede, wordt door middel van deze kwalitatieve typeringen rekening gehouden met het feit dat de prognoses een mate van onzekerheid hebben. Ten derde, verdient de kwalitatieve typering de voorkeur boven een interpretatie in termen van kwantitatieve 'tekorten' en 'overschotten' die geregeld in beleid en media wordt toegepast door de kwantitatieve vraag en aanbod van elkaar af te trekken. De prognoses zijn niet bedoeld als sturingsinstrument voor 'manpower planning' $4{ }^{\circ}$ Bovendien is een interpretatie in termen van kwantitatieve 'tekorten' en 'overschotten' feitelijk onjuist en overschat de kwantitatieve omvang van de disbalans op de arbeidsmarkt omdat bij een onevenwicht tussen vraag en aanbod 1) prijs aanpassingen (via veranderingen in loon) het evenwicht naar verwachting zullen terugbrengen, 2) gediplomeerden in richtingen die in overaanbod zijn, zullen wijken naar andere banen en 3) werkgevers naar substitutiemogelijkheden zullen zoeken wanneer zij niet aan personeel kunnen komen. ${ }^{41}$ Een interpretatie van de typeringen binnen een interval van waarden geeft dit beter weer dan de absolute waarden.

\section{Vernieuwde opleidingsclassificatie naar niveau en richting (ONR2019)}

Met ingang van 2019 hanteert ROA een nieuwe opleidingsclassificatie, de opleidingsclassificatie naar niveau en richting (ONR2019). De nieuwe classificatie is ingevoerd omdat de codering van de onderwijsrichting in de EBB veranderd is van ISCEDF1997 naar ISCEDF2013. Hierdoor kan de sinds 2015 gebruikte opleidingsclassificatie ${ }^{42}$ niet meer worden afgeleid uit de data van de EBB. De opleidingsclassificatie is opgezet in nauwe samenwerking met CBS en het UWV en maakt op verzoek van gebruikers van POA een onderscheid tussen alle niveaus van het mbo. ${ }^{43}$ De opleidingsclassificatie onderscheidt de volgende niveaus: basisonderwijs, vmbo/vmbo1, vmbo-g/t, havo-,vwo-onderbouw, havo/vwo, mbo 2, mbo 3, mbo 4, bachelor (hbo en wo), en master (hbo en wo) of hoger. Binnen deze niveaus worden drie aggregatieniveaus gebruikt, sector (33 sectoren), subsector (52 subsectoren), en type (137 typen). In deze rapportage bespreken we de resultaten op het niveau van subsectoren vanaf mbo 2 en kunnen daarmee meer detail geven dan met de vorige opleidingsclassificatie. Met de invoering van de ONR2019 is de vergelijkbaarheid met eerdere prognoses naar opleidingen niet goed te maken omdat de verschillende opleidingsrichtingen nu uit andere opleidingen samengesteld kunnen zijn. In het AIS worden alle resultaten gerapporteerd op het niveau van de ONR2019type.

40 Cörvers, F., Heijke, J. A. M., \& de Grip, A. (2002). Beyond manpower planning: a labour market model for the Netherlands and its forecasts to 2006. In Forecasting labour markets in OECD countries (pp. 185-223). Edward Elgar Publishing.

41 M. Wieling en L. Borghans (2001), Discrepancies between supply and demand and adjustment processes in the labour market, Labour, 15: 33-56.

42 ROA (2016). ROA opleidingsindeling 2015. Maastricht: ROA-TR-2016/3.

43 De nieuwe classificatie is gedocumenteerd in Bakens, J., Dijksman, S., Fouarge, D. (2019) Opleidingsclassificatie naar Niveau en Richting 2019: Achtergronddocumentatie. Maastricht: ROA-TR-2019/1. 
In Bijlage B staat de volledige opleidingsclassificatie die gebruikt wordt in deze rapportage. Om de classificatie breder bruikbaar te maken dan alleen voor de arbeidsmarktprognoses, is de classificatie beschikbaar voor alle opleidingsniveaus in Nederland, dus ook de lagere niveaus waarover niet gerapporteerd wordt in deze rapportage. Tevens is de opleidingsindeling beschikbaar bij CBS. 



\section{1 \\ DE ARBEIDSMARKT IN VOGELVLUCHT}

\subsection{Inleiding}

De arbeidsmarkt is continu in beweging. In dit hoofdstuk wordt kort ingegaan op de belangrijkste arbeidsmarktontwikkelingen van de afgelopen decennia, en worden de belangrijkste verwachte ontwikkelingen tot 2024 beschreven. Het beschrijven van de arbeidsmarktconjunctuur aan de hand van arbeidsparticipatie, werkloosheid, vacaturegraad en loonontwikkeling in het verleden geeft een beeld van de volatiliteit en de aanpassingsmechanismen op de arbeidsmarkt in tijden van groei en krimp. Bovendien geeft dit ook inzicht in trends die meer structureel van aard zijn en die ook op de middellange termijn (de komende zes jaar) een rol zullen blijven spelen. De verwachte ontwikkelingen in het tweede deel van dit hoofdstuk worden verbijzonderd naar bedrijfssector, beroepsklasse en opleidingsniveau, en deze verwachtingen worden vergeleken met de structurele ontwikkelingen in de afgelopen 20 jaar. De confrontatie tussen de verwachte vraag- en aanbodontwikkelingen op de middellange termijn is bepalend voor de perspectieven van toekomstige gediplomeerden, afgestudeerden, en werkzoekenden op de arbeidsmarkt. De perspectieven naar opleidingsniveau komen aan bod aan het einde van dit hoofdstuk.

\subsection{Actuele ontwikkelingen op de arbeidsmarkt}

\section{Werkloosheid}

Figuur 1.1 toont de ontwikkeling van de werkloosheid in Nederland, en het werkloosheidspercentage voor jongeren en ouderen, alsook de mutatie van het bruto binnenlands product (BBP). Deze laatste geeft de conjuncturele ontwikkeling over de jaren weer, en wordt beschouwd als een goede indicatie van de ontwikkelingen in de werkloosheid die op korte termijn te verwachten zijn. Een periode waar het BBP hoger ligt, wat wijst op een meer gunstige conjunctuur, zou in principe gevolgd moeten worden door een periode van lagere werkloosheid. Het verwachte negatieve verband tussen het BBP en de werkloosheid zien we duidelijk in de periode na de kredietcrisis in 2008 en de eurocrisis in 2012. Vanaf 2008 observeren we een daling van het BBP, welke in 2009 het laagste punt 
bereikte. Na een licht herstel, nam de groei van het BBP opnieuw af in 2012. In dezelfde periode steeg de werkloosheid van 3,7\% in 2008 tot $7,3 \%$ in 2013 .

De jeugdwerkloosheid nam sterker toe (van 8,6\% tot 13,2\%) dan de werkloosheid onder ouderen (van 3,8\% tot 6,5\%). Vanaf 2014 zien we een herstel van de economie; het BBP nam toe tot 2017, en de werkloosheid daalde. Voor de jongeren, die het hardst getroffen werden door de recessie na de kredietcrisis van 2008, nam de werkloosheid af vanaf 2013 tot $7,2 \%$ in 2018. Voor de ouderen daalde de werkloosheid met vertraging pas vanaf 2015 , tot $4,4 \%$ in 2018. Het gemiddelde voor alle leeftijdsklassen samen ligt iets lager op 3,8\%, en de werkloosheid laat in de eerste helft van 2019 een nog verdere daling zien. Vanaf 2017 zien we een daling in de groei van het BBP, waarbij de vraag is in welke mate de werkloosheid verder zal dalen.

FIGUUR 1.1 Ontwikkeling in werkloosheid en volumemutatie van het bruto binnenlands product (BBP), 2003-2018

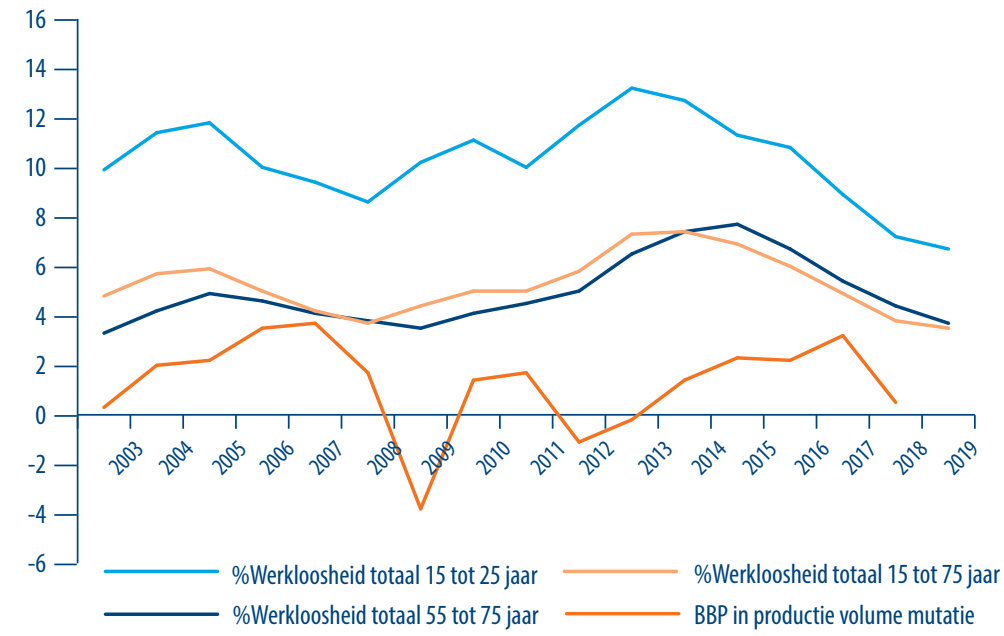

Bron: CBS (Statline), eigen bewerking 


\section{FIGUUR 1.2 Ontwikkeling in werkloosheid per leeftijdscategorie, 2003-2019*}

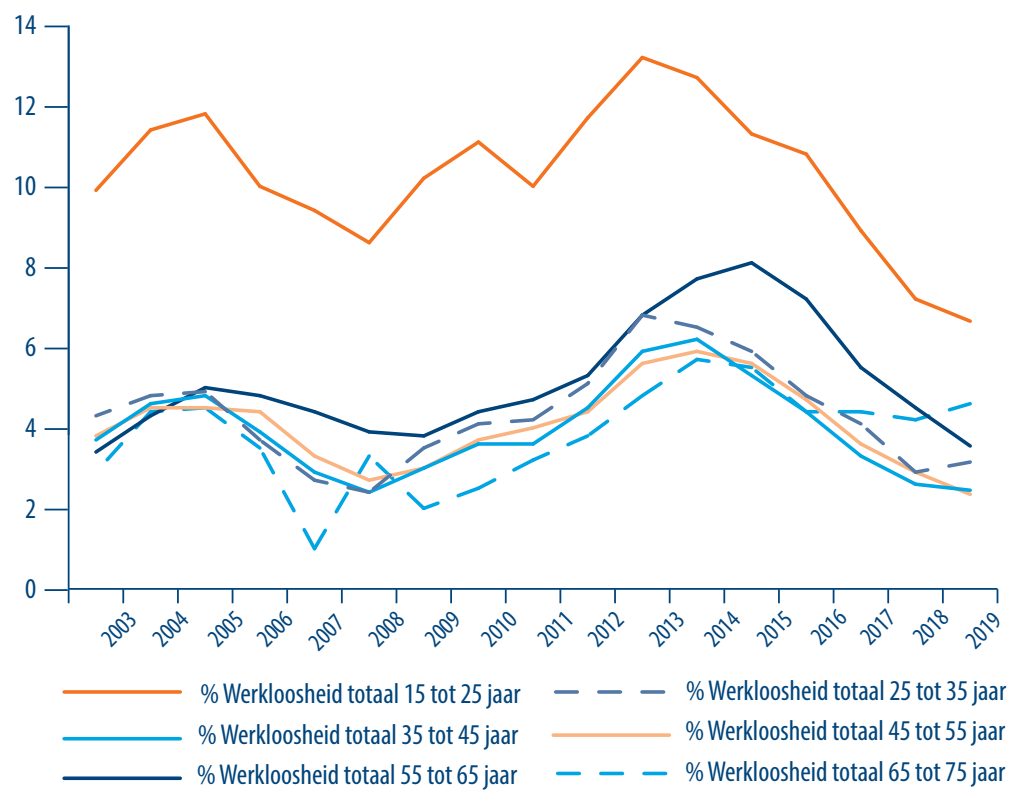

* Meting van 2019 heeft alleen betrekking op de eerste helft van 2019

Bron: CBS (Statline), eigen bewerking

In figuur 1.2 wordt de werkloosheid verder verbijzonderd naar leeftijdscategorieën tussen de 15 en 75 jaar. In 2019 is de werkloosheid historisch laag, en is het niveau van voor de kredietcrisis van 2008 al bereikt. Opvallend is dat de werkloosheid onder jongeren tot 25 jaar sterk gedaald is de afgelopen jaren. Alleen voor personen tussen de 65 en 75 jaar stijgt de werkloosheid. De stijgende werkloosheid onder ouderen kan verband houden met de stijgende arbeidsdeelname van ouderen door de verhoging van de pensioenleeftijd. Als ouderen namelijk werkloos raken, komen zij moeilijker aan een baan en leidt dit tot een hogere langdurige werkloosheid onder ouderen. Het CPB voorspelt overigens voor de komende jaren weer een lichte toename in de werkloosheid door het afzwakken van de economische groei. ${ }^{44}$

44 CPB, Macro Economische Verkenning 2020 (Septemberraming). https://www.cpb.nl/macro-economischeverkenning-mev-2020 


\section{FIGUUR 1.3 Werkloosheid naar opleidingsniveau, 2003-2019*}

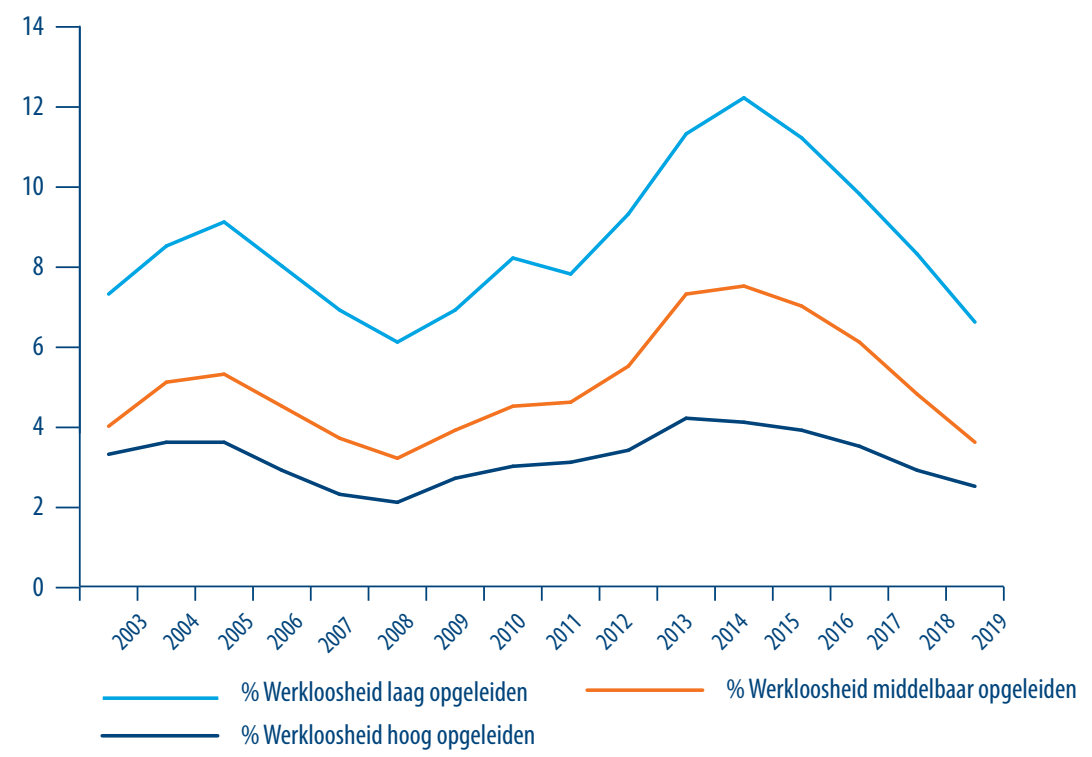

* Meting van 2019 heeft alleen betrekking op de eerste helft van 2019 Bron: CBS (Statline), eigen bewerking

Niet alleen leeftijd, maar ook het opleidingsniveau geeft een specifieker beeld van de werkloosheidsontwikkeling. Figuur 1.3 toont de werkloosheid naar opleidingsniveau. De werkloosheidsgraad onder laagopgeleiden ligt structureel hoger dan de werkloosheid voor middelbaar- en hoogopgeleiden. In de afgelopen jaren is de werkloosheid voor de laagst opgeleiden echter wel het sterkst gedaald. De werkloosheid voor laagopgeleiden ligt in 2019 op bijna 7\%. Ook voor de andere opleidingsniveaus ligt de werkloosheid in 2019 laag, op 3,4\% voor middelbaar opgeleiden en op 2,3\% voor laagopgeleiden. Het werkloosheidspercentage verschilt sterk tussen laag- en hoogopgeleiden, maar voor alle groepen geldt dat deze historisch zeer laag is.

Er zijn twee groepen op de arbeidsmarkt voor wie de werkloosheid structureel hoger ligt, en voor wie een aantrekkende, bloeiende economie niet per se een beter perspectief biedt op een baan. Het gaat om jongeren tussen de 15 en 25 jaar, en ouderen tussen de 65 en 75 jaar. Figuur 1.4 geeft de werkloosheid weer onder jongeren ( 15 tot 25 jaar) naar opleidingsniveau. De werkloosheid van laagopgeleiden ligt een stuk hoger dan voor de middelbaar opgeleiden en voor de hoogopgeleiden. Structureel gaat het om verschillen van respectievelijk 6-7\%-punten en 7-8\%-punten. Het relatief hoge werkloosheidsniveau onder laagopgeleide jongeren hangt samen met de stijgende vraag naar hoogopgeleiden. ${ }^{45}$ Vanaf 2017 is het verschil in werkloosheidspercentage tussen verschil-

45 Bijlsma, l., S. Dijksman, D. Fouarge \& A. Künn (2015). Winnaars en verliezers op de arbeidsmarkt 1996-2012. Tijdschrift voor Arbeidsvraagstukken, 31(2): 106-123. 
lende opleidingsniveaus echter afgenomen aangezien de daling van de werkloosheid na 2015 minder sterk is onder middelbaar en hoogopgeleiden dan onder lager opgeleiden. Een andere ontwikkeling die de sterkere daling in de werkloosheidsgraad van lager opgeleiden kan verklaren, is dat het arbeidsaanbod van laagopgeleide jongeren is afgenomen omdat zij doorleren. Bij een gelijkblijvende arbeidsvraag komt dit dus neer op een daling van het werkloosheidspercentage.

FIGUUR 1.4 Werkloosheid bij jongeren (15-25 jaar), naar opleidingsniveau, 2003-2019*

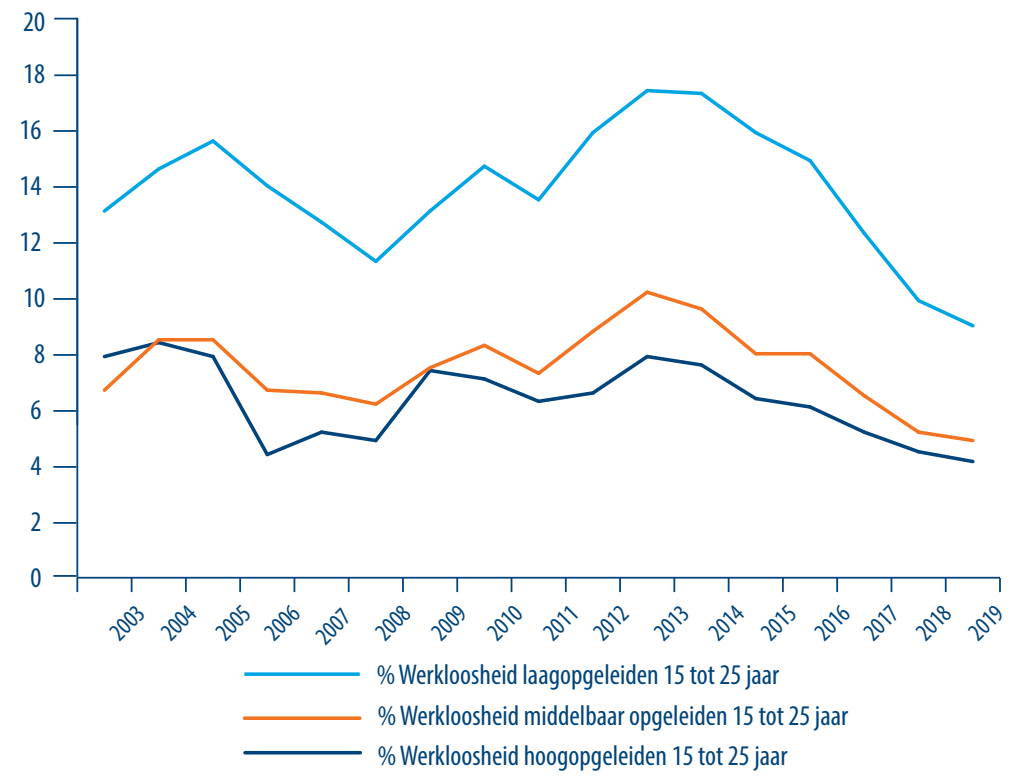

* Meting van 2019 heeft alleen betrekking op de eerste helft van 2019 Bron: CBS (Statline)

Net als in figuur 1.4 geeft figuur 1.5 de werkloosheid naar opleidingsniveau weer, ditmaal onder 55-75 jarigen. Een verschil is echter dat in dit geval het werkloosheidscijfer voor de middelbaar opgeleiden dichter aansluit bij dat van de laagopgeleiden. Het is duidelijk dat er tussen 2012 en 2014 een forse toename was van de werkloosheid onder alle drie de groepen; voor de laag- en middelbaar opgeleiden het meest. Tussen 2014 en 2015 bereikte de werkloosheid voor deze drie groepen het hoogste niveau met voor de laag-, middelbaar, en hoogopgeleiden een werkloosheidspercentage van respectievelijk $9,4 \%, 9 \%$, en 5,6\%. Het stapsgewijs verhogen van de AOW-leeftijd beïnvloedt de werkloosheidscijfers onder ouderen, aangezien ouderen langer tot de werkzame bevolking gerekend worden. Vanaf 2015 is er wel een verbetering zichtbaar en zijn de huidige werkloosheidscijfers van $4,1 \%$, $4 \%$ en 3,2\% respectievelijk voor lager, middelbaar en hoger opgeleiden bijna op het niveau van 2003. Als we de werkloosheidspercentages tussen 2003 en 2019 voor jongeren en ouderen vergelijken, zien we een gelijkaardig patroon, 
maar een verschil in niveau. Bij de ouderen bedraagt de werkloosheidsgraad over deze periode gemiddeld $5 \%$ ten opzichte van $9,2 \%$ bij de jongeren. In beide gevallen scoren de lager opgeleiden het slechts (13,8\% bij de jongeren en $5,6 \%$ bij de ouderen).

\section{FIGUUR 1.5 Werkloosheid bij ouderen (55-75 jaar), naar opleidingsniveau, 2003-2019*}

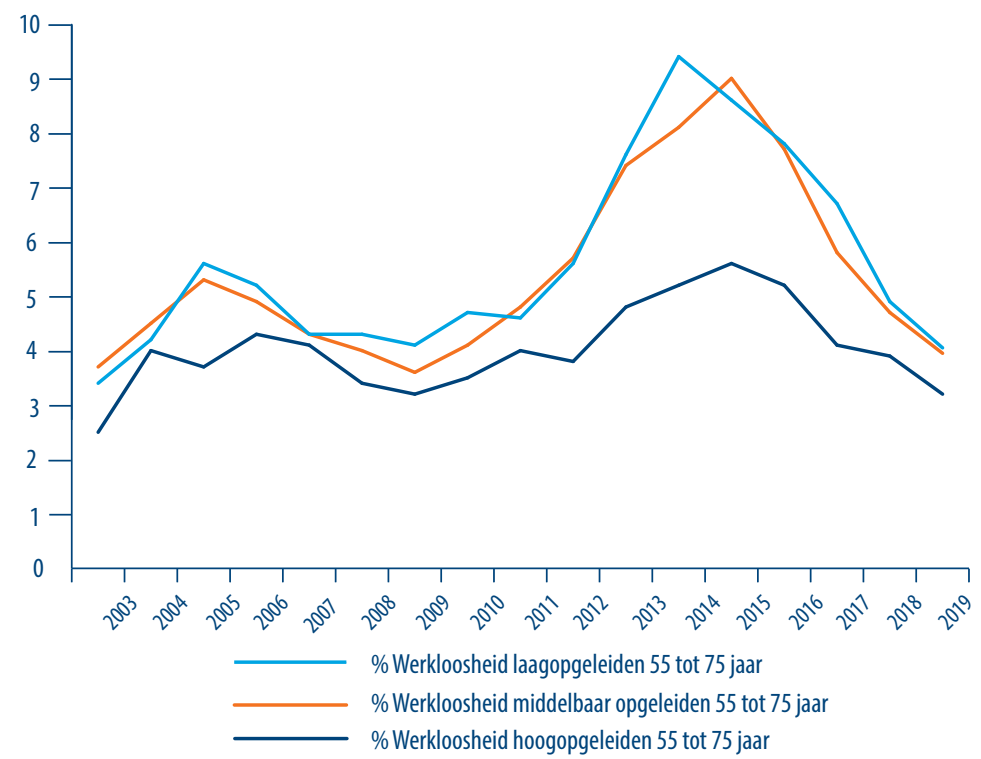

* Meting van 2019 heeft alleen betrekking op de eerste helft van 2019 Bron: CBS (Statline)

\section{Arbeidsparticipatie en flexibele arbeidsrelaties}

Figuur 1.6 laat over de periode van 2003 tot en met 2017 een stijging zien van het aandeel werkenden met een flexibele arbeidsrelatie. Deze stijging is met name zichtbaar onder jongeren. Van 2003 tot 2019 is het aandeel jongeren met een flexibel contract toegenomen van $42 \%$ naar $68 \%$. Figuur 1.6 laat zien dat de flexibilisering van de arbeidsmarkt voor jongeren al begonnen is vóór de kredietcrisis. Ook tijdens de periode van economische groei van de afgelopen jaren bleef het percentage jongeren met een flexibele arbeidsrelatie toenemen. Voor de andere twee leeftijdscategorieën zien we dat het aandeel werknemers met een flexibel contract tussen de 25 en 55 jaar licht is gestegen vanaf 2011, terwijl dit aandeel redelijk stabiel bleef voor de oudere werknemers. Flexibilisering van de arbeidsmarkt lijkt voor bedrijven in tijden van economische tegenslag een middel om de bedrijfsomvang makkelijk aan te passen door het aanbieden van flexibele arbeidscontracten. Voor jongeren lijkt dit echter een structurele trend die minder sterk samenhangt met de conjuncturele cyclus van de economie. 
Wat het aandeel zelfstandigen betreft, zien we in dezelfde figuur dat dit tussen 2003 en 2019 is toegenomen, echter minder uitgesproken dan voor de werknemers met een flexibele aanstelling. In tegenstelling tot de vorige groep, zijn het hier vaker ouderen tussen 55 en 75 jaar die als zelfstandige werken, het aandeel ligt in deze leeftijdscategorie stabiel tussen $24 \%$ en $25 \%$. Wel is het de groep van de 25 - en 55 -jarigen die het sterkst is gestegen onder de zelfstandigen (bijna 4\%-punt tussen 2003 en 2019). De kleinste groep is deze van jongeren die als zelfstandige werken.

FIGUUR 1.6 Percentage zelfstandigen en werknemers met flexibele arbeidsrelatie, naar leeftijd (\%), 2003-2019*

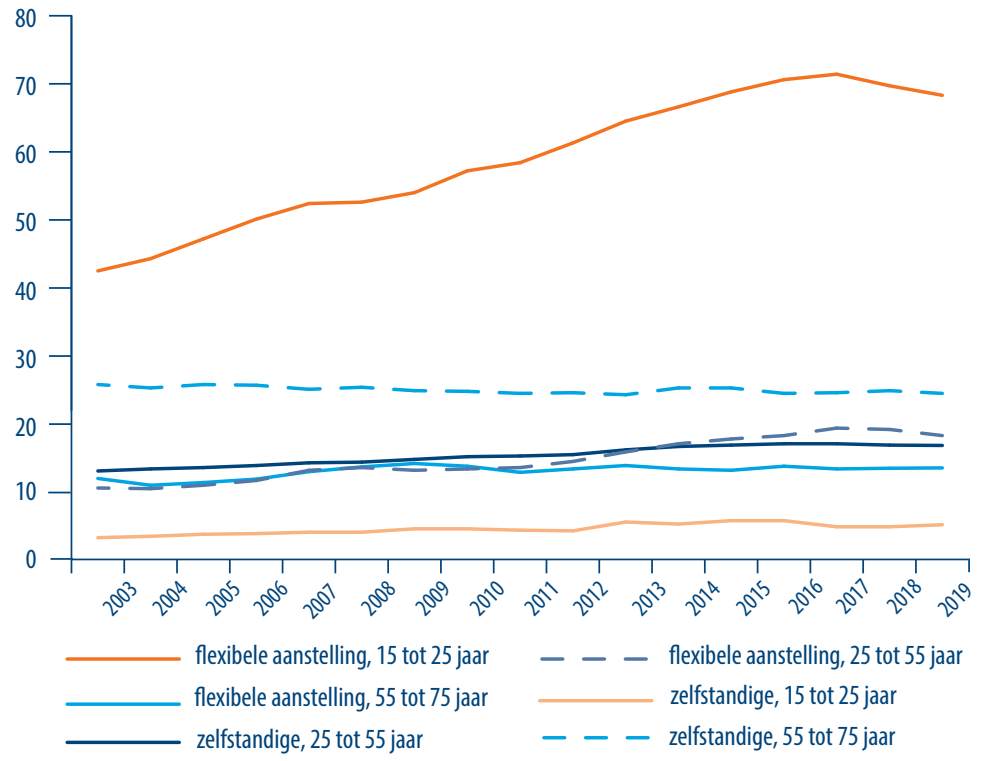

* Meting van 2019 heeft alleen betrekking op de eerste helft van 2019

Bron: CBS (Statline)

Hetzelfde beeld wordt geschetst als we naar de flexibilisering op de arbeidsmarkt kijken per opleidingsniveau. Figuur 1.7 laat over de periode van 2003 tot en met 2019 de ontwikkeling van de positie in de werkkring zien voor laag-, middelbaar, en hoogopgeleiden, geïndexeerd op 2003. Hoewel het aandeel flexibele arbeidscontracten voor laagopgeleiden altijd al hoger lag dan voor middelbaar en hoogopgeleiden, is het aandeel flexibele arbeidscontracten voor laagopgeleiden sinds 2011 fors toegenomen. De laatste 2 jaar laat voor middelbaar en hoogopgeleiden een afname zien van het percentage werkenden met een flexibele arbeidsrelatie, maar dit geldt niet voor laagopgeleiden.

In de snelgroeiende economie van de afgelopen jaren, hebben hoogopgeleiden weer vaker vaste contracten gekregen, of zijn ze vaker zelfstandige geworden. Een groter aantal middelbaar opgeleide werkenden heeft in de afgelopen paar jaar weer een vast 
dienstverband gekregen, terwijl de laagopgeleiden niet meer vastigheid gekregen hebben. De groei in het aandeel laagopgeleide werkenden met een flexibel arbeidscontract houdt aan. De positie van jonge, laagopgeleide werknemers of werkzoekenden is in dit opzicht dus veel onzekerder dan de arbeidsmarktpositie van andere groepen.

FIGUUR 1.7 Percentage zelfstandigen en werknemers, naar opleidingsniveau (index 2003=100), 2003-2019*

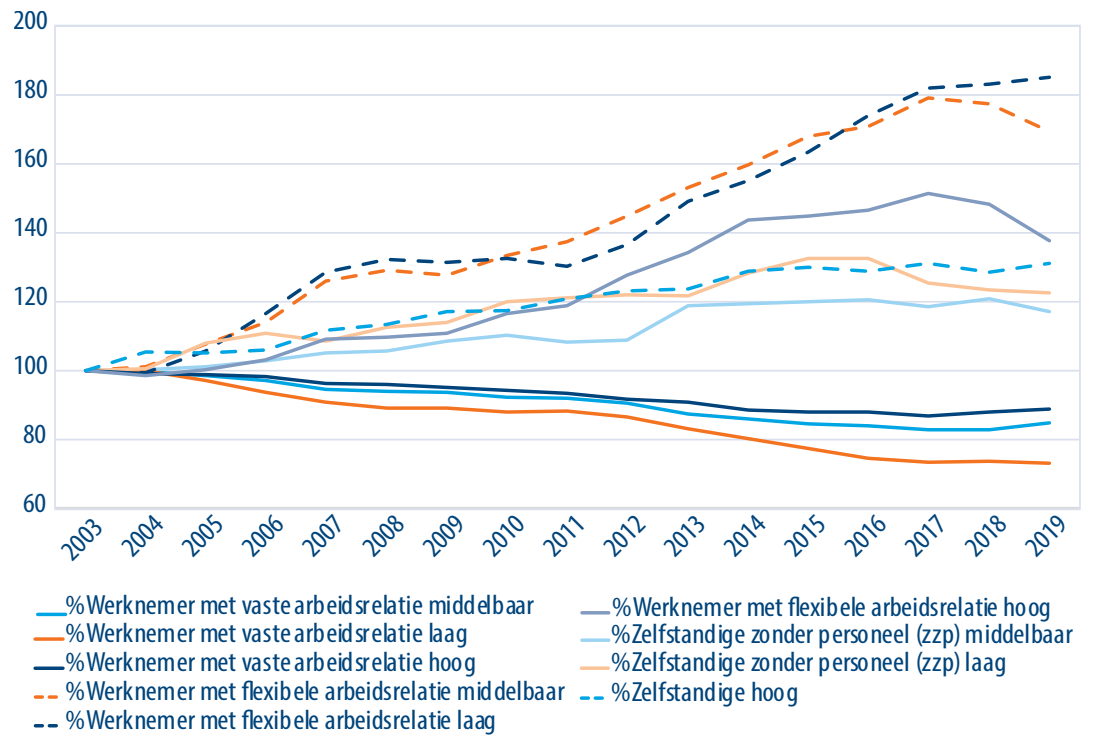

* Meting van 2019 heeft alleen betrekking op de eerste helft van 2019

Bron: CBS (Statline)

\section{Vacaturegraad en werkloosheid}

Effecten van de conjunctuurcyclus op de arbeidsmarkt kunnen zichtbaar worden gemaakt door te kijken naar de veranderingen van het aantal vacatures en werklozen. Bij een aantrekkende economische groei zullen er meer vacatures ontstaan, wat met enige vertraging tot een lagere werkloosheid zal leiden. Het verband tussen de vacaturegraad en het werkloosheidspercentage is dus negatief: een stijgend (dalend) aantal vacatures leidt tot minder (meer) werklozen. Figuur 1.8 geeft dit verband weer voor Nederland van 2003 tot 2019 in de zogenaamde 'Beveridge' curve (Unemployment-Vacancy curve, oftewel UV-curve).

De Beveridge curve laat een stijging zien van de werkloosheidsgraad van 2003 tot 2005 , gevolgd door een daling van 2005 tot 2008 . In dezelfde periode neemt de vacaturegraad toe. Vanaf 2008 zien we dat de werkloosheidsgraad sterk toeneemt van 3,7\% tot 7,4\% in 2014. Dit gaat gepaard met een daling van de vacaturegraad van $32 \%$ in 2008 tot $15 \%$ 
in 2014. Vanaf 2014 zien we een forse verbetering doordat de werkloosheidsgraad daalt en de vacaturegraad stijgt, met in 2019 percentages van respectievelijk 3,5\% en 34\%. De situatie in 2019 illustreert goed de grote krapte aan personeel op de arbeidsmarkt.

FIGUUR 1.8 Relatie tussen vacaturegraad* en werkloosheid** in Nederland, 2003-2019

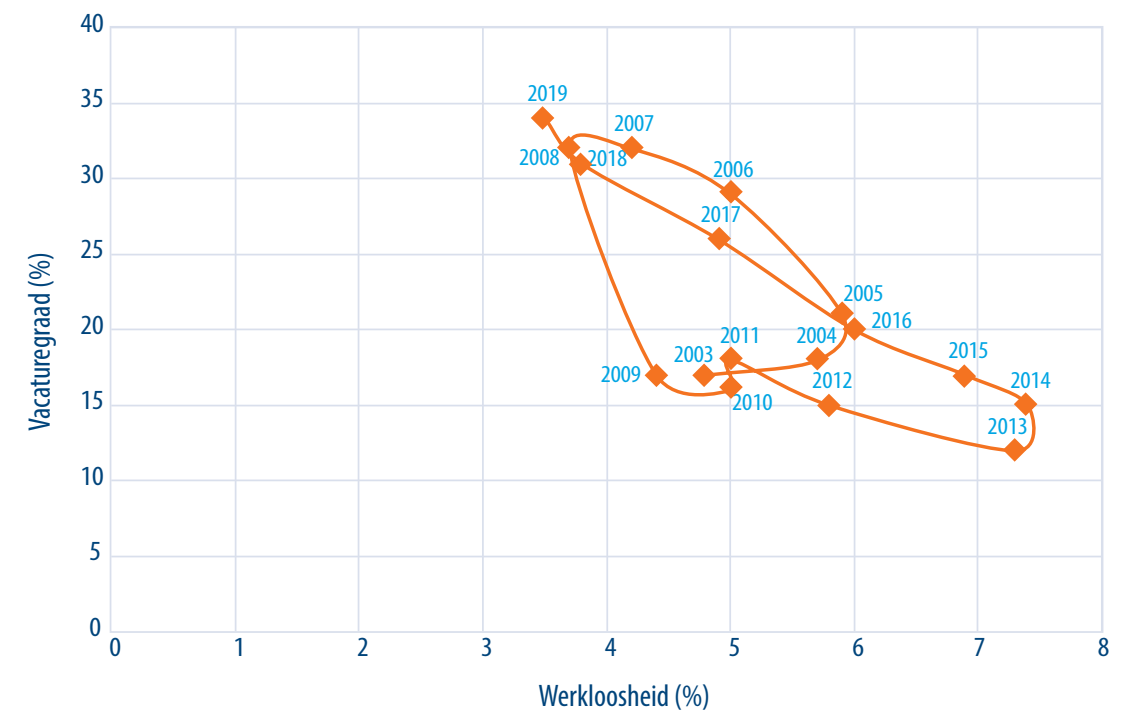

* Betreft de vacaturegraad in de eerste helft van het jaar.

** Betreft de gemiddelde werkloosheid per jaar. Meting van 2019 heeft alleen betrekking op de eerste helft van 2019.

Bron: CBS (Statline)

\section{Loonontwikkeling, arbeidsparticipatie, en werkgelegenheid}

De analyses tot nu toe laten helder zien dat economische cycli effecten hebben op de werkgelegenheid, en dat deze effecten verschillen tussen leeftijdsgroepen en opleidingsniveaus. Of er veel of weinig werklozen zijn, en of bedrijven makkelijk of moeilijk personeel kunnen vinden, heeft gevolgen voor de prijs van arbeid: het loon. Over het algemeen geldt dat als de werkgelegenheid of arbeidsparticipatie in een bepaalde sector of voor een bepaalde beroepsgroep toeneemt terwijl het aanbod gelijk blijft, het loon voor deze werkenden omhoog zal gaan. Figuur 1.9 laat de relatie zien tussen de netto arbeidsmarktparticipatie in Nederland en het gemiddelde bruto uurloon tussen 2008 en 2018. Vooral tussen 2010 en 2014 daalden zowel de participatie als de lonen sterk. We zien dat de arbeidsparticipatie weer op het niveau van voor de recessie zit, maar dat de ontwikkeling van het gemiddelde bruto uurloon hapert. Dit komt vooral omdat de inflatie de afgelopen 2 jaar sterker toeneemt dan daarvoor, waardoor het reele loon minder hard stijgt en tussen 2016 en 2017 zelfs daalt. De stagnatie in de loonontwikkeling is opvallend gezien de krapte op de arbeidsmarkt. 
FIGUUR 1.9 Relatie tussen de netto arbeidsmarktparticipatie en het gemiddelde bruto uurloon** van werknemers, 2003-2018*

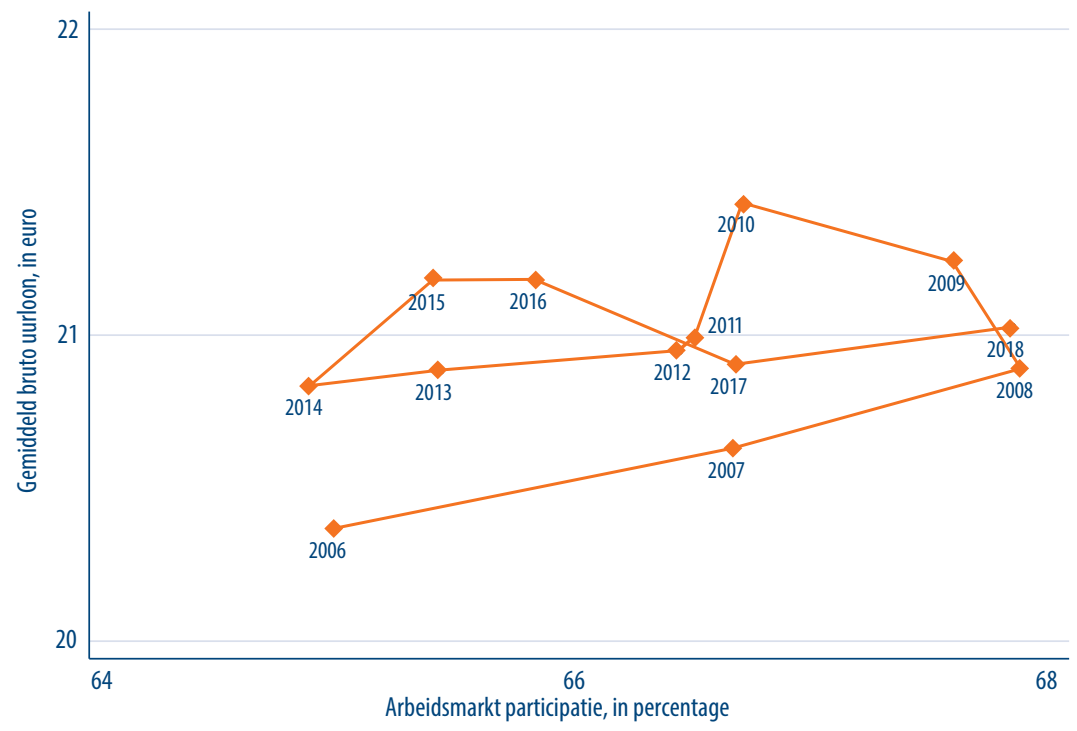

* Het bruto uurloon voor 2018 is een voorlopig cijfer.

** Het bruto uurloon is gegeven in constante prijzen van 2015.

Bron: ROA, EBB-SSB (ROA bewerking)

Het verband tussen het bruto uurloon en arbeidsmarktparticipatie is niet voor alle opleidingsniveaus hetzelfde. In figuur 1.10 zijn de arbeidsparticipatie en het gemiddelde uurloon voor laag-, middelbaar, en hoogopgeleiden afgebeeld voor de periode 20082018. De cijfers zijn geïndexeerd op 2008 omdat het verschil in loon- en participatieniveau tussen de opleidingsgroepen een goede vergelijking in de weg staat. In 2008 was het gemiddelde participatieniveau voor laagopgeleiden 51\%, voor middelbaaropgeleiden gemiddeld $74 \%$, en voor hoogopgeleiden $82 \%$. Het gemiddelde uurloon voor deze groepen was in 2008, respectievelijk, $€ 16, € 19$, en $€ 28$ (in constante prijzen). Wat de figuur vooral goed laat zien, is dat een kredietcrisis voor laagopgeleide werkenden heel andere arbeidsmarkteffecten heeft gehad dan voor hoogopgeleiden. Daar waar laagopgeleiden vanaf 2010 zowel fors inleverden op het loon als op werkgelegenheid, hebben hoogopgeleiden in veel mindere mate ingeleverd op het loon en minimaal op de participatie. Voor de middelbaaropgeleiden blijkt dat er tijdens de economische crisis ook een aanpassing was door zowel een lager uurloon als een lagere arbeidsmarktparticipatie. Bij het aantrekken van de economie vanaf 2014, nemen de participatiecijfers voor alle opleidingsniveaus weer toe, maar de loonontwikkeling blijft achter. Vooral voor laag opgeleiden stijgt het loon niet en wordt het loon in reële termen zelfs lager. Over het algemeen kan gesteld worden dat de hoogopgeleiden tijdens de kredietcrisis hun baan konden behouden door een lager uurloon te accepteren, of een baan beneden het niveau voor een lager uurloon te accepteren. Hierbij kan sprake zijn van verdringing van 
lager opgeleiden door hoger opgeleiden. Desondanks zijn er geen aanwijzingen dat er structureel sprake is van verdringing op de Nederlandse arbeidsmarkt. ${ }^{46}$

FIGUUR 1.10 Relatie tussen de netto arbeidsmarktparticipatie en het gemiddelde bruto uurloon* naar opleidingsniveau van werknemers, geïndexeerd (2008=100) 2008-2018

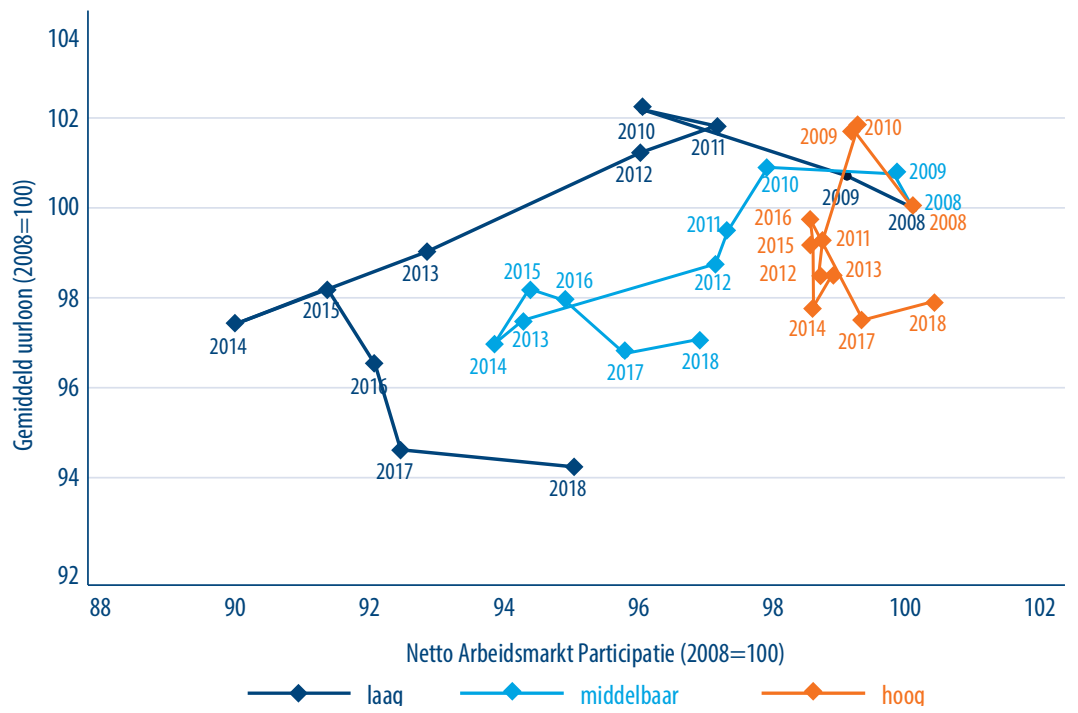

* Het indexcijfer voor het bruto uurloon is berekend op basis van het uurloon in constante prijzen van 2015.

Bron: ROA, EBB-SSB (ROA bewerking)

Uit figuur 1.10 blijkt ook dat de arbeidsparticipatie voor alle opleidingsniveaus in 2017 en 2018 verder toeneemt, maar dat de lonen stagneren. De afgelopen jaren is er veel aandacht voor de achterblijvende lonen in een opgaande economische conjunctuur. Deze 'vertraagde loonontwikkeling' houdt verband met een lage groei van de arbeidsproductiviteit. ${ }^{47}$ Bovendien neemt het gedeelte van de inkomsten van bedrijven dat wordt besteed aan de inputfactor arbeid af. Een groter gedeelte van de winst blijft dus bij bedrijven en wordt niet gebruikt voor het betalen van werknemers. Deze trend is al ver voor de kredietcrisis van 2008 ingezet, en duidt op een steeds kapitaalintensievere productiestructuur in Nederland, en ook op een toenemende ongelijkheid in Nederland tussen kapitaal en arbeid.

46 Wiljan van den Berge, Jan Dirk Vlasblom, Jos Ebregt, Lisa Putman, Jochem Zweerink en Marloes de Graaf-Zijl (2018). Verdringing op de arbeidsmarkt. Den Haag: Centraal Planbureau / Sociaal en Cultureel Planbureau.

47 CPB 2018, Vertraagde loonontwikkeling in Nederland ontrafeld, CPB policy brief 2018/2,

https://www.cpb.nl/sites/default/files/omnidownload/CPB-Policy-Brief-2018-12-Vertraagdeloonontwikkeling-in-nederland-ontrafeld.pdf 
FIGUUR 1.11 Relatie tussen de groei van het gemiddelde bruto uurloon* en de werkgelegenheid naar beroepsklasse, 2008-2018

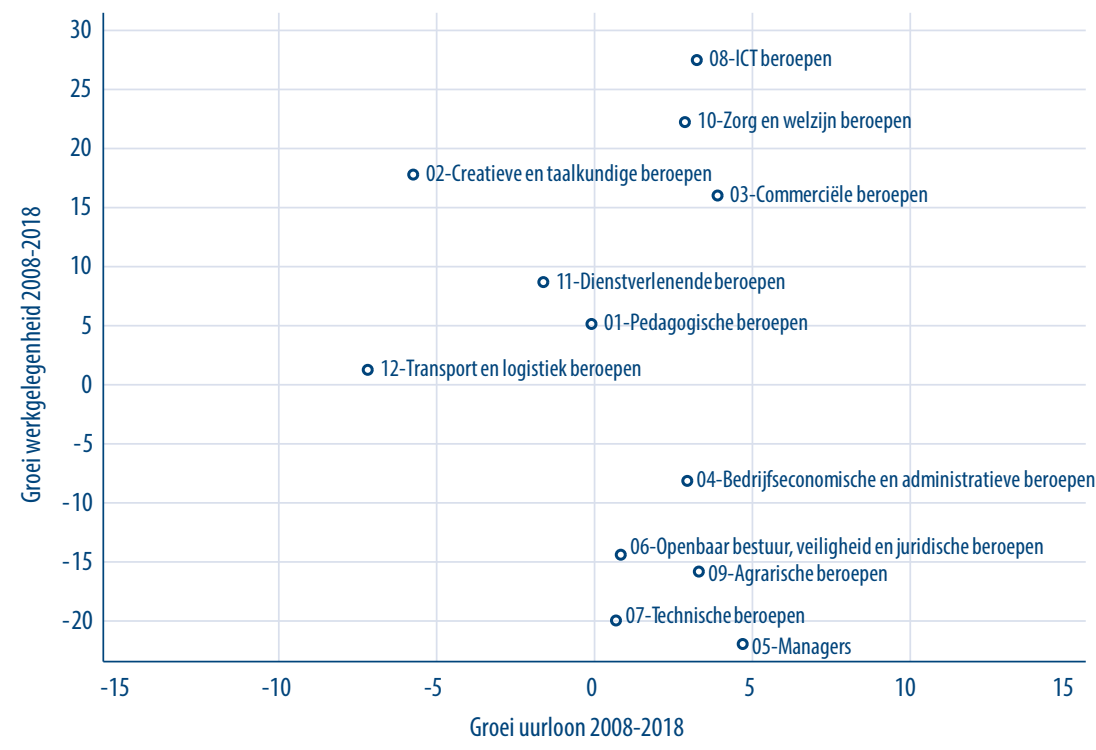

* Het indexcijfer voor het bruto uurloon is berekend op basis van het uurloon in constante prijzen van 2015.

Bron: ROA, EBB-SSB (ROA bewerking)

Zoals uit alle bovenstaande figuren duidelijk blijkt, blijft de loonontwikkeling op de arbeidsmarkt achter. Dit is ook het geval voor die beroepen waar grote krapte heerst of waar een sterke werkgelegenheidsgroei te zien is over de afgelopen 20 jaar. Dit blijkt uit figuur 1.11, waar de werkgelegenheidsgroei naar beroepsklassen wordt afgezet tegen de loonontwikkeling. Voor de meeste beroepsklassen was er een (kleine) stijging in het reële uurloon tussen 2008 en 2018, maar de loongroei lijkt niet af te hangen van de werkgelegenheidsgroei.

Tussen 2008 en 2018 is de werkgelegenheid voor ICT-beroepen, beroepen in de zorg en welzijn, en commerciële beroepen het meeste toegenomen. Dit ging gepaard met een relatief kleine stijging in het reële loon. De grootste daling in loon is voor de transport en logistiek beroepen. Opmerkelijk is verder dat de huidige tekorten aan technisch personeel, niet in overeenstemming zijn met de structurele trend van de afgelopen 20 jaar, waarin er een daling van de werkgelegenheid voor technische beroepen is geweest met een kleine loonstijging. 


\subsection{Verwachtingen voor arbeidsvraag en -aanbod op de middellange termijn}

De arbeidsmarktprognoses van het ROA die in dit rapport worden gepresenteerd hebben betrekking op de periode 2019-2024. Voor het vaststellen van de arbeidsmarktprognoses worden de, bij het opstarten van dit project, meest recent beschikbare ramingen voor de groei van de Nederlandse economie van het Centraal Planbureau (CPB) gebruikt (zie Doel en opzet in dit rapport). Deze ramingen worden door ROA verwerkt in de prognosemodellen om zo tot prognoses te komen voor de verwachte werkgelegenheidsontwikkelingen op de Nederlandse arbeidsmarkt op de middellange termijn. De verwachting is dat de economische groei in Nederland stabiliseert ten opzichte van de groei van de afgelopen jaren.

Tabel 1.1 geeft enkele cijfers weer voor de geprognotiseerde arbeidsmarktontwikkelingen in de periode 2019-2024. De geraamde jaarlijkse werkgelegenheidstoename is 0,9\% ten opzichte van 2018 (gemeten in aantal werkenden dat 1 uur of meer werkt per week). Met andere woorden, over de periode 2019-2024 wordt verwacht dat de werkgelegenheid toeneemt.

TABEL 1.1 Prognoses arbeidsmarktontwikkeling 2019-2024 als gemiddeld jaarlijks percentage van de werkgelegenheid in 2018

\begin{tabular}{|l|c|} 
& $2019-2024$ \\
\hline Werkgelegenheidstoename & $(\%)$ \\
\hline Arbeidsmarktuitstroom & 0,9 \\
\hline Baanopeningen (arbeidsvraag) & 2,9 \\
\hline Arbeidsmarktinstroom gediplomeerden (arbeidsaanbod) & 3,6 \\
\hline
\end{tabular}

${ }^{1}$ Het gaat hierbij om personen die het initiële dag-, deeltijd, niet-reguliere voltijdonderwijs en de beroepsgerichte volwasseneducatie verlaten

Bron: ROA (AIS)

De arbeidsmarktuitstroom vertelt ons dat er naar schatting gemiddeld 2,9\% van de werkenden per jaar de arbeidsmarkt verlaat o.a. vanwege pensionering, arbeidsongeschiktheid of zorgtaken. Dit betekent echter niet dat er evenveel personen vervangen dienen te worden. De werkelijke vervangingsvraag, de effectieve vraag naar nieuwe werkenden ter vervanging van deze die de arbeidsmarkt verlaten, wordt geschat op 2,8\% per jaar (zie hoofdstuk 3). Bovendien kan een deel van de uitstroom en vervangingsvraag ook te wijten zijn aan het feit dat personen een niveauverhogende of richtingveranderende opleiding volgen naast hun werk, en zo van opleidingsachtergrond veranderen.

We schatten het aantal baanopeningen (de arbeidsvraag) op 3,6\% per jaar in. Dit geeft de ruimte voor nieuwkomers op de arbeidsmarkt weer, als gevolg van groei in de totale 
werkgelegenheid door uitstroom van werkenden en baancreatie (vervangingsvraag en uitbreidingsvraag). ${ }^{48}$

Wat betreft het arbeidsaanbod, wordt de arbeidsmarktinstroom van gediplomeerden geschat op 2,9\% per jaar ten opzichte van het basisjaar. Als we dit percentage vergelijken met de arbeidsvraag of het aantal baanopeningen, dan kunnen we hieruit afleiden dat er op de middellange termijn verwacht wordt dat het voor gediplomeerden relatief gemakkelijk zou moeten worden om een baan te vinden aangezien de vraag groter is dan het aanbod. Het reservoir aan (kortdurig) werklozen is, zo zagen wij aan het begin van dit hoofdstuk, klein. De krapte op de arbeidsmarkt zal echter minder zijn wanneer mensen die nu niet werken, maar bij een stijgende arbeidsvraag dit wel willen doen, zich op de arbeidsmarkt aanbieden. Hoe groot dit aanbod is, laat zich moeilijk schatten.

\subsection{Verwachte werkgelegenheidsontwikkeling naar bedrijfssector}

Het stabiliseren van de economische groei zien we ook terug als we naar de werkgelegenheidsontwikkeling naar bedrijfssector kijken. In deze paragraaf vergelijken we voor de werkgelegenheidsontwikkeling, de prognoses voor de periode 2019-2024 met de trends voor de afgelopen 22 jaar per bedrijfssector. Tabel 1.2 geeft naast de trends en prognoses, ook het aantal werkenden over de jaren 2017-2018 weer. Gemiddeld over deze jaren, was het aantal personen dat minimaal 1 uur per week werkzaam was bijna 8,7 miljoen. De sectoren met de grootste werkgelegenheid zijn de detailhandel (881.000), welzijn (716.000), en specialistische zakelijke dienstverlening (631.000). De kleinste sectoren zijn energie (73.000), de chemische industrie (126.500), en de voedingsen genotsmiddelenindustrie (148.000). Wanneer we in de derde kolom kijken naar de trend over de laatste 22 jaar, dan zien we dat de gemiddelde jaarlijkse groei van de werkgelegenheid $0,9 \%$ was. Cultuur, sport en recreatie $(3,1 \%)$; zorg $(2,5 \%)$; en informatie en communicatie $(2,2 \%)$ waren de sectoren die het sterkst groeiden. 6 van de 21 sectoren zagen de werkgelegenheid krimpen waarbij de metaalindustrie $(-1,4 \%)$, de groothandel $(-1,2 \%)$ en de voedings- en genotsmiddelenindustrie $(-1,2 \%)$ de grootste negatieve groei kenden.

Wat betreft de sectorprognoses, wordt tot 2024 een jaarlijkse groei van de werkgelegenheid van gemiddeld o,9\% verwacht. Naar verwachting hebben 6 sectoren van de 21 te kampen met een werkgelegenheidskrimp. Volgens deze prognoses, zullen de sectoren informatie en communicatie $(3,1 \%)$, zorg $(2,1 \%)$, en bouwnijverheid $(1,9 \%)$, de grootste groeiers zijn. De grootste krimp is te verwachten in de landbouw, bosbouw en visserij $(-1,2 \%)$, de chemische industrie $(-0,8 \%)$ en vervoer en opslag $(-0,6 \%)$. Het valt op dat de voorspelde groeipercentages aanzienlijk kunnen afwijken van de historische. Bij de sector cultuur en recreatie ligt de historische groeitrend zelfs 2,4\%-punt boven de geprognostiseerde groei. Andere sectoren waar we grote verschillen vinden zijn onderwijs (1,6\%-punt), en vervoer en opslag (1,7\%-punt).

48 Bij de uitbreidingsvraag wordt enkel rekening gehouden met de bruto werkgelegenheidsgroei voor de segmenten waarvoor de werkgelegenheidsontwikkeling positief is. 
TABEL 1.2 Ontwikkeling van het aantal werkenden per bedrijfssector 1996-2018, en de uitbreidingsvraag naar bedrijfssector 2019-2024, gemiddelde jaarlijkse groei in beide gevallen als percentage van het basisjaar (2018)

\begin{tabular}{|c|c|c|c|}
\hline & \multicolumn{3}{|c|}{ Werkgelegenheidsontwikkeling } \\
\hline & $\begin{array}{c}\text { Aantal werkenden } \\
\text { gem. } \\
\text { 2017-2018 }\end{array}$ & $\begin{array}{c}\text { Feitelijk } \\
1996-2018 \\
\text { (\%) }\end{array}$ & $\begin{array}{c}\text { Prognose } \\
2019-2024 \\
(\%)\end{array}$ \\
\hline Landbouw, bosbouw en visserij & 173.500 & $-0,6$ & $-1,2$ \\
\hline Voedings- en genotmiddelenindustrie & 148.000 & $-1,2$ & 0,4 \\
\hline Chemische industrie & 126.500 & $-1,2$ & $-0,8$ \\
\hline Metaalindustrie & 289.000 & $-1,4$ & $-0,3$ \\
\hline Overige industrie & 255.000 & $-0,7$ & $-0,5$ \\
\hline Energie & 73.000 & 0,8 & $-0,1$ \\
\hline Bouwnijverheid & 412.000 & 1,0 & 1,9 \\
\hline Detailhandel & 881.000 & 1,2 & 0,6 \\
\hline Groothandel & 403.500 & $-1,2$ & 0,3 \\
\hline Vervoer en opslag & 401.000 & 1,1 & $-0,6$ \\
\hline Horeca & 393.000 & 1,9 & 0,7 \\
\hline Informatie en communicatie & 287.000 & 2,2 & 3,1 \\
\hline Financiële dienstverlening en onroerend goed & 322.000 & 0,0 & 0,1 \\
\hline Specialistische zakelijke dienstverlening & 631.000 & 2,2 & 1,4 \\
\hline Verhuur en overige zakelijke dienstverlening & 467.000 & 0,8 & 1,3 \\
\hline Openbaar bestuur en overheidsdiensten & 503.500 & 0,5 & 0,3 \\
\hline Onderwijs & 577.500 & 1,6 & 0,0 \\
\hline Zorg & 604.500 & 2,5 & 2,1 \\
\hline Welzijn & 716.000 & 2,2 & 1,8 \\
\hline Cultuur, sport en recreatie & 179.000 & 3,1 & 0,7 \\
\hline Overige dienstverlening, huishoudens en extraterritoriale organisaties & 196.000 & 0,8 & 0,8 \\
\hline Totaal (incl. overig) & 8.677 .000 & 0,9 & 0,9 \\
\hline
\end{tabular}

Bron: ROA (AIS)

Ondanks de aantrekkende economie blijven de landbouw, bosbouw en visserij, en de industrie en energiesector lijden onder negatieve banengroei. Met een geschatte jaarlijkse krimp van de werkgelegenheid van 1,2\% zal de landbouw-, bosbouw-, en visserijsector haar door mechanisering en schaalvergroting ingegeven negatieve historische trend in de komende jaren naar verwachting voortzetten. Voor de krimpende sectoren geldt echter wel dat de voorspelde krimp minder groot is dan de langjarige trend. Er is overigens een groot aantal sectoren waarvoor de groei voor de middellange termijn weliswaar positief blijft, maar minder sterk is dan de werkgelegenheidsgroei in de afgelopen 22 jaar. Dit geldt onder meer voor de onderwijssector, die van gemiddeld 1,6\% per jaar terugvalt naar nulgroei, hetgeen verklaard kan worden door de daling van het 
geboortecijfer. Andere sectoren die aanzienlijk minder hard groeien dan tijdens de afgelopen 22 jaar zijn cultuur, sport en recreatie $(0,7 \%)$ en horeca $(0.7 \%)$.

Ten opzichte van de vorige prognoses (die tot 2022 liepen) ${ }^{49}$, valt het vooral op dat de ramingen voor de groei in de industrie tegenvallen, en in vervoer en opslag. Deze sectoren die afhankelijk zijn van (internationale) handel, ondervinden minder groei als gevolg van de aanblijvende onzekerheden omtrent Brexit, en andere geopolitieke spanningen die handelsrelaties tussen verschillende landen onder druk zetten. Ook de groei in de zorgsector werd in 2017 nog geraamd op 3,1\%, terwijl deze nu onder de langetermijngroei ligt op 2,1\%. Een grote groei wordt verwacht voor specialistische verhuur en overige zakelijke dienstverlening (was $0,4 \%$ tot 2022) en informatie en communicatie (was 1,4\% tot 2022).

\subsection{Verwachte werkgelegenheidsontwikkeling naar beroepsklasse}

De werkgelegenheidsgroei naar beroep wordt afgeleid uit de werkgelegenheidsgroei van de verwachte groei naar bedrijfssectoren. Om de vertaalslag van bedrijfssectoren naar beroepen te maken, wordt in het ROA-prognosemodel de beroepenstructuur binnen bedrijfssectoren geschat. Bij deze schatting wordt expliciet rekening gehouden met zowel waargenomen verschuivingen in de beroepenstructuur binnen bedrijfssectoren (d.w.z. intrasectorale verschuivingen) in de jaren 1996-2018 als verschuivingen in de werkgelegenheid tussen bedrijfssectoren (d.w.z. intersectorale verschuivingen). In deze rapportage worden de resultaten naar beroepsklasse besproken, maar in het AIS zijn de prognoses ook beschikbaar per beroepsgroep, op een lager aggregatieniveau. ${ }^{50}$ Vanzelfsprekend kunnen de hier gepresenteerde prognoses naar beroepsklassen uiteenlopen voor de onderliggende beroepsgroepen.

Tabel 1.3 geeft in essentie dezelfde verwachte ontwikkelingen weer als tabel 1.2, ditmaal voor beroepsklassen in plaats van bedrijfssectoren. De bedrijfseconomische en administratieve beroepen zorgen voor de meeste werkgelegenheid in Nederland (1.591.000), gevolgd door de technische beroepen (1.237.500) en de zorg en welzijn beroepen (1.191.500). Tot de kleinste beroepsklassen behoren de agrarische beroepen (192.000), de creatieve en taalkundige beroepen (214.500), en de openbaar bestuur, veiligheid en juridische beroepen (294.500). Wanneer we kijken naar de historische trend over de afgelopen 22 jaar, dan zien we de grootste groei respectievelijk in de pedagogische beroepen en creatieve en taalkundige beroepen (beide $2 \%$ ), en de ICT-beroepen (1,9\%). De agrarische en technische beroepen zagen daarentegen een werkgelegenheidskrimp, respectievelijk $-1,6 \%$ en $-0,6 \%$. De groei voor de komende zes jaar ligt op hetzelfde niveau als het langjarige gemiddelde, namelijk op $0.9 \%$, ditmaal met de zorg en welzijn beroepen bovenaan de lijst van sterkste groeiers $(2,2 \%)$, gevolgd door de creatieve en taalkundige beroepen $(1,6 \%)$ en de ICT-beroepen $(1,3 \%)$. Over het algemeen, lijkt de situatie te verbeteren, aangezien er in tegenstelling tot de vorige versie van dit rapport geen

49 ROA (2017). De arbeidsmarkt naar opleiding en beroep tot 2022. Maastricht: ROA-R-2017/10.

50 ROA/CBS (2015). Beroepenindeling ROA-CBS 2014 (BRC 2014). Maastricht: ROA-TR-2015/5. 
krimp wordt geraamd. Enkel de agrarische beroepen krijgen in de prognoseperiode te maken met nulgroei.

TABEL 1.3 Aantal werkenden per beroepsklasse, de feitelijke ontwikkeling van het aantal werkenden per beroepsklasse in de periode 1996-2018, en de verwachte ontwikkeling van het aantal werkenden per beroepsklasse in de periode 2019-2024, gemiddelde jaarlijkse groei als percentage van de werkgelegenheid in het basisjaar

\begin{tabular}{|l|c|c|c|} 
& \multicolumn{3}{|c|}{ Werkgelegenheidsontwikkeling } \\
& Aantal werkenden & Feitelijk & Prognose \\
& gem. & $1996-2018$ & $2019-2024$ \\
\hline & $2017-2018$ & $(\%)$ & $(\%)$ \\
\hline Pedagogische beroepen & 601.500 & 2,0 & 0,3 \\
\hline Creatieve en taalkundige beroepen & 214.500 & 2,0 & 1,6 \\
\hline Commerciële beroepen & 975.500 & 0,6 & 0,3 \\
\hline Bedrifseconomische en administratieve beroepen & 1.591 .000 & 1,1 & 0,6 \\
\hline Managers & 431.500 & 1,0 & 1,3 \\
\hline Openbaar bestuur, veiligheid en juridische beroepen & 294.500 & 1,7 & 0,6 \\
\hline Technische beroepen & 1.237 .500 & $-0,6$ & 0,9 \\
\hline ICT beroepen & 353.000 & 1,9 & 1,3 \\
\hline Agrarische beroepen & 192.000 & $-1,6$ & 0,0 \\
\hline Zorg en welzijn beroepen & 1.191 .500 & 1,8 & 2,2 \\
\hline Dienstverlenende beroepen & 810.500 & 1,3 & 0,6 \\
\hline Transport en logistiek beroepen & 626.500 & 1,4 & 0,6 \\
\hline Totaal (incl. overig) & 8.677 .000 & 0,9 & 0,9 \\
\hline
\end{tabular}

Bron: ROA (AIS))

Alhoewel de verwachte jaarlijkse toename van de werkgelegenheid over alle beroepsklassen heen tot en met 2024 gelijk is aan de structurele trend tussen 1996 en 2018, wordt voor de meeste beroepsklassen een minder hoge groei verwacht de komende zes jaar. De grootste uitbreidingsvraag wordt verwacht voor de zorg en welzijn beroepen (2,2\%), wat gedeeltelijk komt door de stijgende vraag en overheidsuitgaven aan zorg. Ook voor de technische beroepen wordt een veel hogere groei verwacht voor de komende zes jaar dan de structurele krimp van de afgelopen 22 jaar. Voor de technische beroepen komt dit deels door de gunstige perspectieven in de bouwnijverheid, maar ook gedeeltelijk doordat technici profiteren van de groei in andere sectoren van de economie.

\subsection{Verwachte werkgelegenheidsontwikkeling naar opleidingsniveau}

In deze paragraaf gaan we, net als in de vorige twee, de historische trend van de werkgelegenheid vergelijken met de prognoses, ditmaal vanuit het perspectief van de opleidingen in plaats van sectoren en beroepen. In tabel 1.4 zien we deze gegevens voor 7 opleidingsniveaus evenals het aantal werkenden tussen 2017 en 2018. Deze tabel moet als volgt gelezen worden; van de bijna 8,7 miljoen werkenden in die periode, heeft bijna 2 miljoen een hbo- of wo-bachelor als hoogst behaalde diploma. Dit is de grootste groep. Opvallend is dat 1.768 .000 van de werkenden maximaal een basisonderwijs of 
vmbo-diploma behaalden. Echter, binnen deze groepen volgt een deel momenteel nog een vervolgopleiding terwijl ze ook werkzaam zijn, bijvoorbeeld in een scholieren baan. Mbo 2 vormt met 566.000 werkzame personen, de kleinste groep.

Wanneer we vervolgens kijken naar de werkgelegenheidsontwikkeling over de afgelopen 22 jaar, dan zien we dat de hbo- en wo-bachelor en master (respectievelijk 2,3\% en $2,1 \%$ per jaar) gemiddeld de grootste groei hebben gekend. Het basisonderwijs en vmbo $(-2,6 \%)$, het mbo $2(-1,2 \%)$, en het mbo $3(-0,7 \%)$ zagen de werkgelegenheid dalen. Dit is in lijn met de ontwikkeling dat de Nederlandse beroepsbevolking steeds hoger opgeleid is. Het valt op dat in de prognoses voor de komende jaren, de groeipercentages niet erg verschillen tussen de opleidingsniveaus, en dat bovendien het mbo 3 zelfs de grootste groei kent $(1,1 \%)$. De kleinste groeicijfers worden verwacht voor het havo en vwo en het basisonderwijs en vmbo (allemaal o,7\% per jaar).

TABEL 1.4 Aantal werkenden per opleidingsniveau, de feitelijke ontwikkeling van het aantal werkenden per opleidingsniveau in de periode 1996-2018 en de verwachte ontwikkeling van het aantal werkenden per opleidingsniveau in de periode 2019-2024, gemiddelde jaarlijkse groei als percentage van de werkgelegenheid in het basisjaar

\begin{tabular}{|l|c|c|c|} 
& \multicolumn{3}{|c|}{ Werkgelegenheidsontwikkeling } \\
& Aantal werkenden & Feitelijk & Prognose \\
& gem. & $1996-2018$ & $2019-2024$ \\
\hline basisonderwijs, vmbo & $2017-2018$ & $\%$ & $\%$ \\
\hline havo/vwo & 1.768 .000 & $-1,1$ & 0,7 \\
\hline mbo 2 & 802.000 & 0,5 & 0,7 \\
\hline mbo3 & 566.000 & $-1,2$ & 0,9 \\
\hline mbo 4 & 800.000 & $-0,7$ & 1,1 \\
\hline hbo-, wo-bachelor & 1.431 .500 & 1,8 & 0,9 \\
\hline hbo-, w0-master, doctor & 1.955 .500 & 2,3 & 0,9 \\
\hline Totaal (incl. overig) & 1.246 .500 & 2,1 & 0,8 \\
\hline Bron: ROA (AlS) & 8.677 .000 & 0,9 & 0,9 \\
\hline
\end{tabular}

Bron: ROA (AIS)

De verschillen tussen de groeivoeten voor de periode 1996-2018 per opleidingsniveau zijn minder groot in de prognoses voor 2019-2024. Voor alle opleidingsniveaus wordt namelijk een positieve en relatief gelijkwaardige groei van de werkgelegenheid voorspeld. De verwachte relatieve toename van de werkgelegenheid voor personen met bachelor en master als hoogst genoten opleiding voor de komende zes jaar is minder dan de helft van de jaarlijkse groei over de afgelopen 22 jaar. De stijging van het aantal werkenden met een hoge opleiding over de afgelopen jaren houdt verband met een steeds beter opgeleide beroepsbevolking in Nederland en met skills-upgrading; voor hetzelfde werk is iemand nodig met hogere skills. De verwachting volgens de prognoses is dat deze trend zich enkel nog beperkt blijft voortzetten op masterniveau. 
Voor werkenden met basisonderwijs, vmbo en havo/vwo is de verwachte gemiddelde jaarlijkse groei $0,7 \%$, en voor mbo 2 0,9\%. Daarbij moet er ook rekening mee worden gehouden dat laagopgeleiden (al dan niet bezig met een vervolgopleiding) de komende zes jaar gezien hun leeftijd wellicht wel een baan kunnen vinden als bijvoorbeeld kassamedewerker, vakkenvuller, werknemer in de horeca of als hulpkracht in de landbouw. De loopbaanperspectieven op langere termijn voor werkenden met een laag opleidingsniveau zijn echter beduidend slechter (zie paragraaf 1.7). De reden voor de opmerkelijke gunstige wijziging van de werkgelegenheidsontwikkeling voor de lagere opleidingsniveaus hangt ook samen met het feit dat hoewel er structureel sprake is van een krimp in veel laag en middelbaar opgeleide beroepen, er ook laag en middelbaar opgeleide beroepen zijn die verwacht worden te groeien maar waar de werkgelegenheid veelal uit kleine banen bestaat, zoals hulpkrachten in de bouw en industrie of laders, lossers en vakkenvullers. Bovendien zijn laagopgeleiden soms ook werkzaam in beroepen boven hun opleidingsniveau. De groei in die beroepen draagt eveneens bij aan de groei in de vraag naar laagopgeleiden omdat de vraag naar opleidingen afgeleid is van de vraag naar beroepen.

\subsection{Verwachte arbeidsmarktperspectieven naar opleidingsniveau tot 2024}

In deze paragraaf wordt het arbeidsmarktperspectief voor de periode 2019-2024 per opleidingsniveau besproken. De basis voor deze analyse wordt gevormd door de confrontatie tussen de vraag naar en het aanbod van arbeid. Daarbij is de vraag naar gediplomeerden met een bepaald opleidingsniveau gelijk aan de som van de uitbreidingsvraag, de vervangingsvraag en de extra vraag die resulteert uit substitutie- effecten tussen opleidingstypes..$^{51}$ Het totale aanbod van personen met een bepaald opleidingsniveau wordt gegeven door de som van de instroom van gediplomeerden en het aantal kortdurig werklozen..$^{2}$

Om per opleidingsniveau een beeld te krijgen van de toekomstige kansen op de arbeidsmarkt, wordt de Indicator Toekomstige Arbeidsmarktperspectieven naar opleiding (ITA) berekend door het verwachte aanbod per opleidingsniveau (arbeidsmarktinstroom van gediplomeerden en kortdurig werklozen) te delen door de verwachte vraag. De ITA geeft dus de ex ante spanning weer tussen de verwachte vraag- en aanbodontwikkeling van gediplomeerden. Een ITA gelijk aan 1 betekent dat het arbeidsaanbod even groot is als de arbeidsvraag. In dat geval is er dus sprake van een ex ante evenwicht tussen vraag en aanbod. De ITA wordt groter wanneer het verwachte arbeidsaanbod stijgt ten opzichte van de vraag. Bijgevolg wordt het perspectief van gediplomeerden slechter. Omgekeerd, wordt het arbeidsmarktperspectief beter wanneer de ITA daalt. Tabel 1.5 toont voor elk opleidingsniveau de bijbehorende ITA en enkele van haar componenten. In de tabel staat ook een aantal andere indicatoren die de arbeidsmarktperspectieven

51 Deze substitutievraag bestaat uit de extra vraag naar een bepaald opleidingstype als gevolg van aanbodtekorten of -overschotten bij (vanuit arbeidsmarktoogpunt) aanverwante opleidingen. Dit impliceert dat de substitutievraag dus zowel positief als negatief kan zijn.

52 Kortdurig werklozen worden in dit rapport gedefinieerd als personen die minder dan een jaar werkloos zijn. 
verder onderbouwen. Deze indicatoren zijn voornamelijk gekozen om onderscheid te kunnen maken tussen gunstige arbeidsmarktperspectieven op de lange en middellange termijn. Dit is belangrijk nu de definitie van werkenden ook kleine banen (1 uur of meer) omvat, en dus ook scholierenbaantjes.

Tabel 1.5 toont dat voor alle onderscheiden opleidingsniveaus ${ }^{53}$, de vervangingsvraag beduidend groter is dan de uitbreidingsvraag, waardoor het aantal baanopeningen tijdens de periode 2019-2024 vooral gedreven zal worden door de vervangingsvraag. Deze ontstaat doordat werkenden hun baan verlaten wegens pensionering, zwangerschap, arbeidsongeschiktheid of doorstroom op de arbeidsmarkt. Ook de gemiddelde toekomstige jaarlijkse instroom van gediplomeerden is met 3,0\% nog steeds relatief hoog, wat vooral bij mbo-opgeleiden tot iets minder gunstige arbeidsmarktperspectieven leidt. ${ }^{54}$ De ITA over alle opleidingsniveaus heen is echter gelijk aan o,98, wat er op wijst dat de arbeidsmarktperspectieven tot 2024 gemiddeld genomen goed zijn doordat de vraag het aanbod overstijgt. Voor werkgevers betekent dit dat de arbeidsmarkt relatief krap is. Vanzelfsprekend kunnen de hier gepresenteerde prognoses naar opleiding uiteenlopen voor de onderliggende opleidingsrichtingen (zie hoofdstuk 2 en 3).

Mbo 3- en mbo 4-gediplomeerden kennen de minst gunstige ITA-scores. Deze opleidingsniveaus hebben redelijke arbeidsmarktperspectieven en zullen met een ITA van boven de 1 naar verwachting te maken krijgen met een aanbodoverschot wegens een relatief kleinere uitbreidings- en vervangingsvraag en een hoge instroom. De beste arbeidsmarktprognoses worden voorspeld voor hbo- en wo-bachelor (inclusief de AD-opleidingen, zie textbox 1) en -master gediplomeerden, met een goede ITA voor, respectievelijk, $40 \%$ en $42 \%$ van de gediplomeerden binnen deze niveaus. Alhoewel de ITA voor het mbo 4 redelijk is, geldt dat voor $31 \%$ van de gediplomeerden met deze opleidingen goede tot zeer goede perspectieven worden verwacht tot 2024 (doorgaans gaat het hier om gediplomeerden uit technische en zorg richtingen).

De ITA is ook voor het basisonderwijs/vmbo, havo/vwo, en mbo2 goed, maar de overige indicatoren in tabel 1.5 laten zien dat de loopbaanperspectieven voor deze groepen een stuk minder gunstig zijn. ${ }^{55}$ Voor werkenden met deze opleiding op de arbeidsmarkt geldt een relatief hoge vervangingsvraag omdat het vooral gaat om kleinere banen met een laag loon en met een groot aandeel scholieren. Het loopbaanperspectief laat zien dat de loonontwikkeling voor werkenden op de arbeidsmarkt met dit opleidingsniveau slecht of matig is: werkenden tussen de 40 en 49 jaar verdienen 1,4 keer zoveel als werkenden tussen de 20 en 29 jaar. Voor werkenden met een masteropleiding is dit bijna 1,8 keer zo veel. Voor hoger opgeleiden geldt dus niet alleen dat de arbeidsmarktperspectieven

3 In het AIS staan ook de resultaten op een minder geaggregeerde opleidingsindeling.

54 De kortdurige werkloosheid telt mee bij de bepaling van het aanbod naar opleiding op de arbeidsmarkt.

55 De indicator voor loopbaanperspectief is per opleiding berekend aan de hand van de ratio van het bruto uurloon van werkenden in de leeftijdsgroep 20-29 jaar en 40-49 jaar (zie voor een argumentatie Fouarge, D., Kriechel, B., \& Dohmen, T. (2014), Occupational sorting of school graduates: The role of economic preferences. Journal of Economic Behavior \& Organization, 106, 335-351). Deze gegevens zijn verkregen door koppeling van informatie over lonen en gewerkte uren uit het Sociaal Statistisch Bestand (SSB) van CBS (SSB-Banen en de Polis-Bestanden) met informatie over het opleidingstype van EBB- respondenten. 
op de middellange termijn gemiddeld genomen, goed zijn, maar dat ook de loopbaanperspectieven op lange termijn veel beter zijn dan die van laagopgeleiden. Overigens zijn de loopbaanperspectieven voor havo/vwo ook goed, maar dit zou kunnen komen doordat diegene die een vervolgopleiding na het havo/vwo niet afronden dit doen omdat ze op dat moment al een goede positie gevonden hebben op de arbeidsmarkt.

TABEL 1.5 Uitbreidingsvraag, vervangingsvraag en arbeidsmarktinstroom als percentage van de werkgelegenheid in 2018, en de daaruit volgende toekomstige arbeidsmarktperspectieven per opleidingsniveau aangevuld met het percentage gediplomeerden waarvoor een goed tot zeer goed arbeidsmarktperspectief wordt verwacht, het gemiddelde loonniveau, het gemiddeld aantal gewerkte uren per week, en het aandeel scholieren in de werkgelegenheid

\begin{tabular}{|c|c|c|c|c|c|c|c|c|}
\hline Indicatoren & $\begin{array}{l}\text { Basis- } \\
\text { onder- } \\
\text { wijs, } \\
\text { vmbo }\end{array}$ & $\begin{array}{r}\text { havo/ } \\
\text { vwo }\end{array}$ & mbo 2 & mbo 3 & mbo 4 & bachelor & master & totaal \\
\hline Uitbreidingsvraag (\%) & 0,7 & 0,7 & 0,9 & 1,1 & 0,9 & 0,9 & 0,8 & 0,9 \\
\hline Vervangingsvraag (\%) & 4,4 & 1,5 & 3,0 & 2,2 & 2,5 & 2,6 & 2,7 & 2,9 \\
\hline Instroom (\%) & 2,2 & 0,9 & 2,9 & 3,4 & 3,6 & 3,3 & 3,3 & 2,9 \\
\hline ITA & 0,89 & 0,98 & 0,97 & 1,03 & 1,01 & 1,00 & 1,00 & 0,98 \\
\hline Typering ITA & goed & goed & goed & redelijk & redelijk & goed & goed & goed \\
\hline (zeer) goed perspectief (\%) & 74 & 100 & 46 & 14 & 31 & 40 & 42 & 43 \\
\hline Loopbaanperspectief & 1,35 & 1,84 & 1,44 & 1,39 & 1,42 & 1,63 & 1,75 & 1,58 \\
\hline Uurloon $(€)$ & 15 & 18 & 19 & 19 & 20 & 26 & 32 & 22 \\
\hline Gewerkte uren (per week) & 26 & 25 & 33 & 33 & 33 & 33 & 35 & 31 \\
\hline Aandeel scholieren (\%) & 22,2 & 12,3 & 0,6 & 0,3 & 0,4 & 0,1 & 0,0 & 5,8 \\
\hline
\end{tabular}

Bron: ROA (AIS) 
Om de kloof tussen het mbo en het hbo te verkleinen, besloot de Nederlandse overheid in 2006 om naast hbo-bacheloropleidingen ook zogenaamde Associate degree (Ad)-opleidingen aan te bieden. Dit zijn tweejarige hbo-opleidingen die studenten opleiden tot niveau 5 van het Nederlands Kwalificatieraamwerk (NLQF). Daarmee positioneert de Ad zich tussen mbo 4 en hbo-bachelor. Enerzijds richten Ad-opleidingen zich op mbo 4- of havo-gediplomeerden die willen doorstromen naar het hoger onderwijs om hun vakkennis te verbreden en te verdiepen, maar de stap naar een vierjarige hbo-bacheloropleiding te groot vinden. Anderzijds richten Ad-opleidingen (en dan met name de deeltijd en duale varianten) zich ook op werkenden die zich in het kader van een leven lang ontwikkelen zich willen om- of bijscholen. Na afronding hebben Ad-afgestudeerden de keuze om in twee jaar ook het aansluitende hbo-bachelorprogramma te halen.

Ondanks dat het opleidingstype reeds sinds 2006 bestaat, heerste er nog onduidelijkheid over de relatieve arbeidsmarktpositie van Ad-gediplomeerden. Een recent onderzoek van ROA toont echter dat het brutouurloon van Ad-gediplomeerden twee jaar na afstuderen zich tussen dat van mbo 4-gediplomeerden en hbobachelorgediplomeerden bevindt. ${ }^{56}$ Meer bepaald verdienen recent afgestudeerde Ad'ers een bruto-uurloon dat $12 \%$ hoger is dan dat van mb0 4 (bol)-gediplomeerden, en $11 \%$ lager dan dat van afgestudeerden van een voltijdse hbo-bachelor. Verder hebben voltijdse Ad'ers anderhalf jaar na afstuderen ongeveer evenveel kans om een baan te hebben dan voltijdse hbo-gediplomeerden. Ze hebben daarentegen wel 15 procentpunten meer kans om een baan te hebben die zich onder hun opleidingsniveau en buiten hun opleidingssector bevindt. Mogelijk zou dit een gevolg kunnen zijn van de relatieve onbekendheid van de Ad bij werkgevers.

Een belangrijk verschil tussen Ad-opleidingen en mbo- en hbo-bacheloropleidingen, is de grote omvang van Ad-studenten die kiezen voor deeltijdse of duale opleidingsprogramma's. Deeltijdse en duale opleidingsvormen maken het mogelijk om werk en studie gemakkelijker te combineren, en worden dan ook veelal door werkenden gekozen. Als gevolg hiervan verdienen gediplomeerden van Ad-deeltijd en Ad-duaal twee jaar na diplomering ongeveer $10 \%$ meer dan afgestudeerden van een voltijdse hbo-bachelor. Wel werken zij nog frequenter dan Ad-voltijdgediplomeerden onder hun opleidingsniveau, wellicht omdat zij na afstuderen niet altijd bij hun werkgever kunnen doorgroeien naar een beter betaalde baan.

De populariteit van de deeltijdse en duale variant suggereert echter dat de Ad niet alleen voor uitstromende mbo-afgestudeerden interessant is, maar eveneens voor werkenden die zich zouden willen om- of bijscholen. Derhalve zou dit opleidingstype, en met name de deeltijdse en duale variant, een rol kunnen spelen bij het aanmoedigen van een leven lang leren en de aanpak van arbeidsmarktkrapte in de zorg en techniek. In de huidige opleidingsclassificatie vallen de AD-opleidingen onder de bacheloropleidingen.

\subsection{Conclusie}

De sterke economische groei in Nederland van de afgelopen jaren, vlakt geleidelijk aan af. De arbeidsmarktperspectieven blijven echter over het algemeen gunstig en de werkloosheid is historisch laag (hoewel de ramingen van de werkloosheid voor de komende

56 Allen, J., Belfi, B., Bijlsma, I., Fouarge, D., \& Peeters, T. (2019). Ad-opleidingen: omvang en rendement, Maastricht: ROA-R-2019/4. 
jaren een lichte stijging laten zien). Dit beeld geldt voor alle leeftijdsgroepen, alhoewel de werkloosheid onder jongeren iets sneller lijkt te dalen dan de werkloosheid onder de rest van de beroepsbevolking. Het werkloosheidspercentage onder jongeren lag echter zowel vóór als ná de grote recessie boven het werkloosheidspercentage van de beroepsbevolking als geheel en boven het werkloosheidspercentage onder ouderen. Verder blijkt dat de werkloosheid, ook bij het aantrekken van de economie, structureel hoger ligt voor laagopgeleiden dan voor middelbaar en hoogopgeleiden. Vooral voor laagopgeleide jongeren zijn de werkloosheidspercentages structureel hoger dan die voor jongeren met een hoger opleidingsniveau, of ouderen met een lager opleidingsniveau. Dit hangt samen met de skill-upgrading op de arbeidsmarkt waardoor de vraag naar hoger opgeleiden structureel toeneemt, en de vraag naar lager opgeleiden structureel afneemt.

Een andere opvallende verandering op de arbeidsmarkt, is dat de afgelopen jaren het aandeel werknemers met een flexibele arbeidsrelatie gestaag toenam. Dit geldt voornamelijk voor nieuwe toetreders op de arbeidsmarkt, de jongeren, en voor lager opgeleiden. Deze groep heeft tijdens de krapte op de arbeidsmarkt in de afgelopen jaren geen grote baanzekerheid gekregen in termen van vaste arbeidscontracten, terwijl dit voor hoger opgeleiden wel het geval is. Over de volledige breedte van de arbeidsmarkt blijven de lonen achter bij de werkgelegenheidsontwikkeling, dit geldt vooral voor laag opgeleiden.

Tot 2024 wordt een jaarlijkse werkgelegenheidsgroei van gemiddeld 0,9\% per jaar verwacht. Er zullen de komende jaren naar verwachting dus meer banen bijkomen dan verdwijnen. De bedrijfssectoren waarvoor de sterkste groei wordt verwacht zijn de informatie en communicatie (3,1\% per jaar), zorg (2,1\% per jaar), bouwnijverheid ( $1,9 \%$ per jaar), en welzijn ( $1,8 \%$ per jaar). Voor de landbouw, bosbouw, en visserij, en de industrieën (behalve de voedings- en genotmiddelenindustrie) wordt een negatieve werkgelegenheidsgroei verwacht. Dit geldt ook voor vervoer en opslag (-o,6\% per jaar).

De verwachte werkgelegenheidsgroei uitgesplitst naar beroepsklassen blijkt het grootst te zijn voor de zorg en welzijn beroepen en de creatieve en taalkundige beroepen, met een jaarlijkse groei in de werkgelegenheid van, respectievelijk, 2,2\% en 1,6\%. Er wordt voor geen enkele beroepsklasse een krimp verwacht, enkel voor de agrarische beroepen wordt er een jaarlijkse werkgelegenheidsgroei van o\% verwacht.

De vervangingsvraag blijft de komende jaren veruit de belangrijkste component voor het aantal baanopeningen. De gemiddelde jaarlijkse vervangingsvraag als percentage van de werkgelegenheid bedraagt 2,9\% terwijl de gemiddelde jaarlijkse uitbreidingsvraag slechts 0,9\% bedraagt. Hier staat een gemiddelde jaarlijkse arbeidsmarktinstroom van 2,9\% tegenover waardoor de arbeidsmarkt de komende jaren naar verwachting tekenen van krapte zal blijven laten zien. Over het algemeen geldt dat de perspectieven beter worden naarmate het opleidingsniveau hoger wordt. De geschatte goede verwachte baankansen voor het basisonderwijs, het vmbo, havo/vwo, en mbo 2 komen 
voornamelijk door de grote vraag van werkgevers voor scholieren-/studentenbaantjes. Het betreft echter kleine baantjes met weinig uren, een laag en zonder doorgroeimogelijkheden. Voor het mbo- niveau 3 en 4 zijn de perspectieven redelijk, en goed voor de hbo- en wo-bachelor en -master. Over het algemeen geldt dat de arbeidsmarktperspectieven voor mbo niveau 3 en 4 redelijk zijn en voor bachelor en master afgestudeerden goed.

Specifieke ontwikkelingen op de deelmarkten zullen bepalend zijn voor de vraagaanbodverhoudingen voor specifieke beroepen en opleidingen. In hoofdstuk 2 worden de arbeidsmarktperspectieven naar beroep en opleiding in meer detail beschreven. In hoofdstuk 3 worden de door ons doorgerekende arbeidsmarktperspectieven in detail beschreven aan de hand van de verschillende vraag- en aanbodcomponenten uit het prognosemodel. 


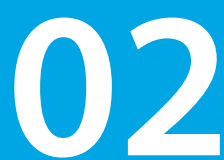

\section{AANSLUITING TUSSEN ONDERWIJS EN ARBEIDSMARKT}

\section{$2.1 \quad$ Inleiding}

In dit hoofdstuk worden de arbeidsmarktprognoses voor de aansluiting tussen vraag en aanbod naar opleiding en beroep tot 2024 besproken. Paragraaf 2.2 besteedt aandacht aan de verwachte arbeidsmarktperspectieven voor gediplomeerden naar opleidingscategorie. In paragraaf 2.3 worden de verwachte knelpunten voor werkgevers in de personeelsvoorziening naar beroep besproken. De besproken knelpunten voor opleidingen en beroepen is gebaseerd op de verschillende vraag- en aanbodcomponenten, waarvan de belangrijkste de uitbreidingsvraag, de vervangingsvraag en de instroom zijn. In hoofdstuk 3 worden alle afzonderlijke componenten van de confrontatie tussen de verwachte ontwikkeling in de vraag naar, en het aanbod van arbeid in detail besproken. Belangrijk is om goed te beseffen dat een grote verwachte arbeidsvraag op zichzelf niet genoeg is om te kunnen concluderen dat de arbeidsmarktperspectieven gunstig zullen zijn. Er kan immers een nog groter arbeidsaanbod tegenover staan waardoor instromers op de arbeidsmarkt sterk met elkaar moeten concurreren voor banen.

De hier gepresenteerde prognoses zijn een indicatie van de nu verwachte discrepantie in vraag-aanbodverhoudingen. Verschillende aanpassingsmechanismen op de arbeidsmarkt spelen een rol om de vraag en het aanbod op de arbeidsmarkt terug in balans te brengen. Wanneer de vraag het aanbod overstijgt, kan er voor instromers op de arbeidsmarkt bijvoorbeeld sprake zijn van een dalende kans op werkloosheid, stijgende lonen, grotere kans op voltijdsbanen, minder onderbenutting, of meer kans op werk in de eigen richting. Het herstellen van de balans tussen vraag en aanbod hoeft dus niet gerealiseerd te worden via het openen of juist sluiten van opleidingsplaatsen. In paragraaf 2.4 worden deze aanpassingsmechanismen in beeld gebracht per opleidingsniveau om een beter beeld te krijgen van de aansluiting tussen het onderwijs en de arbeidsmarkt. Dit doen wij aan de hand van indicatoren voor de huidige aansluiting tussen onderwijs en arbeidsmarkt voor recent gediplomeerden. Paragraaf 2.5 concludeert. 


\subsection{Toekomstige arbeidsmarktperspectieven naar opleiding}

De arbeidsmarktperspectieven naar opleiding worden bepaald door het aanbod van arbeid (kortdurig werklozen en verwachte arbeidsmarktinstroom) en de vraag naar arbeid (verwachte baanopeningen en substitutievraag) te vergelijken aan de hand van de Indicator Toekomstige Arbeidsmarktperspectieven (ITA). Als de vraag en het aanbod voor gediplomeerden met een bepaalde opleiding even groot is, is de ITA gelijk aan 1 en zijn de arbeidsmarktperspectieven voor die opleiding goed: voor elke baanopening is er iemand met een passende opleiding. Als de vraag naar gediplomeerden van een bepaalde opleiding groter is dan het aanbod, dan is de ITA kleiner dan 1, en zullen deze gediplomeerden naar verwachting geen moeite hebben om een baan te vinden. Bij een ITA groter dan 1 is het aanbod van gediplomeerden van een bepaalde opleiding groter dan de vraag, zijn de arbeidsmarktperspectieven minder gunstig en is het moeilijker om een baan te vinden.

Over het algemeen zijn de toekomstige arbeidsmarktperspectieven naar opleiding goed. Voor iets meer dan 40\% van de gediplomeerden, zijn de perspectieven over de periode 2019-2024 zelfs goed of zeer goed. Slechts 3 van de 33 opleidingssubsectoren kennen slechte perspectieven op werk. Terwijl er redelijk wat variatie is tussen verschillende subsectoren, zien we dat er bij de hogere opleidingen, de bachelor en master, vaker gunstige prognoses zijn. Het kan ook voorkomen dat bepaalde opleidingen binnen de subsectoren goed scoren, maar door aggregatie, de subsector slechts redelijk of matig scoort. In de laatste twee kolommen van tabel 2.1 geven we daarom weer wat de verdeling van de ITA's is over de opleidingstypes die onder de subsectoren vallen, gewogen naar het aantal werkenden. Het aandeel van de subsector 'redelijk' wordt niet weergegeven. De gedetailleerde prognoses per opleidingstype zijn in het online AIS terug te vinden

Wanneer we tussen subsectoren vergelijken, zien we dat binnen het mbo 2, de richting zorg en dienstverlening als enige een goed perspectief heeft. Bij deze richting is de instroom kleiner dan het verwachte aantal baanopeningen. De andere drie opleidingen van het mbo 2 (economie en maatschappij, landbouw en natuur, en techniek en ICT), scoren matig tot redelijk. 
TABEL 2.1 Toekomstige arbeidsmarktperspectieven naar opleiding (ITA) voor schoolverlaters, en percentage van het aanbod met matig-slechte, en (zeer) goede perspectieven, 20192024

\begin{tabular}{|c|c|c|c|c|}
\hline ONR2019subsector & ITA & $\begin{array}{l}\text { Typering } \\
\text { arbeidsmarkt- } \\
\text { perspectieven }\end{array}$ & $\begin{array}{l}\text { Matig-slechte } \\
\text { perspectieven } \\
(\%)\end{array}$ & $\begin{array}{l}\text { (Zeer) goede } \\
\text { perspectieven } \\
(\%)\end{array}$ \\
\hline Mbo2 - economie en maatschappij & 1,06 & matig & 100 & 0 \\
\hline Mb02 - landbouw en natuur & 1,02 & redelijk & 0 & 0 \\
\hline Mbo2 - techniek en ICT & 1,03 & redelijk & 0 & 0 \\
\hline Mbo2 - zorg en dienstverlening & 0,99 & goed & 0 & 100 \\
\hline Mbo3 - economie en administratie & 1,08 & matig & 100 & 0 \\
\hline Mbo3 - handel, ondernemerschap, transport en logistiek & 1,18 & slecht & 100 & 0 \\
\hline Mbo3 - voedsel, natuur en leefomgeving & 1,02 & redelijk & 50 & 22 \\
\hline Mbo3 - ICT, media en vormgeving & 1,06 & matig & 59 & 41 \\
\hline Mb03 - techniek, bouw en procesindustrie & 1,01 & redelijk & 0 & 38 \\
\hline Mb03 - dienstverlening & 1,05 & redelijk & 45 & 0 \\
\hline Mb03 - gezondheidszorg en welzijn & 1,02 & redelijk & 0 & 2 \\
\hline Mbo4 - economie en administratie & 1,10 & matig & 100 & 0 \\
\hline Mb04 - handel, ondernemerschap, transport en logistiek & 1,08 & matig & 31 & 0 \\
\hline Mbo4 - voedsel, natuur en leefomgeving & 0,88 & goed & 0 & 100 \\
\hline Mbo4 - ICT, media en vormgeving & 1,22 & slecht & 100 & 0 \\
\hline Mb04 - techniek, bouw en procesindustrie & 0,87 & goed & 0 & 100 \\
\hline Mb04-dienstverlening & 1,10 & matig & 72 & 8 \\
\hline Mbo4 - gezondheidszorg en welzijn & 1,04 & redelijk & 48 & 43 \\
\hline Bachelor - dienstverlening & 1,17 & slecht & 100 & 0 \\
\hline Bachelor - economie en recht & 1,08 & matig & 79 & 0 \\
\hline Bachelor - journalistiek, gedrag en maatschappij & 1,17 & slecht & 100 & 0 \\
\hline Bachelor - kunst, taal en cultuur & 1,05 & redelijk & 75 & 0 \\
\hline Bachelor - landbouw, wiskunde en natuurwetenschappen & 0,97 & goed & 0 & 32 \\
\hline Bachelor - techniek en ICT & 0,87 & goed & 0 & 100 \\
\hline Bachelor - gezondheidszorg en welzijn & 0,99 & goed & 22 & 78 \\
\hline Bachelor - onderwijs & 0,93 & goed & 0 & 100 \\
\hline Master - economie en recht & 1,05 & redelijk & 21 & 23 \\
\hline Master - journalistiek, gedrag en maatschappij & 1,06 & matig & 57 & 0 \\
\hline Master - kunst, taal en cultuur & 1,01 & redelijk & 53 & 47 \\
\hline Master - landbouw, wiskunde en natuurwetenschappen & 1,05 & redelijk & 57 & 0 \\
\hline Master - techniek en ICT & 0,92 & goed & 0 & 100 \\
\hline Master - gezondheidszorg & 0,92 & goed & 0 & 100 \\
\hline Master - onderwijs & 0,96 & goed & 0 & 100 \\
\hline Totaal (incl. bo, vmbo, mbo1, havo/vwo en overig) & 0,98 & goed & 36 & 43 \\
\hline
\end{tabular}

Bron: ROA (AIS) 
Wat betreft mbo 3, zien we een gelijkaardig patroon: de richting economie en administratie en handel, ondernemerschap, transport en logistiek scoren matig en slecht. In deze richtingen scoren zelfs alle (100\%) opleidingen matig of slecht. Voor deze opleidingen geldt dat automatisering en skills-upgrading een belangrijke rol spelen in de dalende vraag naar gediplomeerden met deze achtergrond. Op mbo3-niveau scoort ook ICT, media en vormgeving matig. Op mbo 4-niveau scoren ook ICT-opleidingen slecht. De vraag naar ICT-opgeleiden op de arbeidsmarkt richt zich vooral op de hogere (bachelor en master) niveaus en minder op ICT-vaardigheden op mbo-niveau, zoals ICT-ondersteuning en mediatechniek. Dit constateert ook het UWV. ${ }^{57}$ De overige richtingen binnen het mbo 3 scoren redelijk en de arbeidsmarkt is voor deze opleidingen de komende zes jaar dus redelijk in balans.

De enige twee richtingen met een goed perspectief op mbo 4-niveau zijn voedsel, natuur en leefomgeving, en techniek, bouw en procesindustrie. Bij voedsel, natuur en leefomgeving zorgen een hoge vervangingsvraag door een vergrijzende sector, en een lage instroom voor goede perspectieven. Bij techniek, bouw en procesindustrie zien we ook dat de vervangingsvraag relatief hoog is ten opzichte van de verwachte instroom. Binnen de richting techniek, bouw en procesindustrie hebben alle onderliggende opleidingen een goed perspectief en de opleiding bouw en infra zelfs een zeer goed perspectief. Zowel economie en administratie, handel, ondernemerschap, transport en logistiek, en dienstverlening op mbo4-niveau scoren matig. Relatief gezien is de instroom voor deze opleidingen meer dan voldoende om aan de vraag op de arbeidsmarkt te kunnen voldoen. Vooral voor economie en administratie geldt dat voor alle onderliggende opleidingen slecht tot matige vooruitzichten worden verwacht. Ten slotte zijn de prognoses voor de richting gezondheidszorg en welzijn redelijk, maar de verschillen voor de onderliggende opleidingstypes zijn groot: voor verpleegkunde en medische ondersteuning, en voor laboratorium en gezondheidstechniek gelden (redelijk) goede perspectieven, terwijl de perspectieven voor pedagogisch werk en sociaal en maatschappelijk werk matig zijn.

Binnen de bacheloropleidingen zien we grote verschillen in de arbeidsmarktprognoses tot 2024. Landbouw, wiskunde en natuurwetenschappen, techniek en ICT, gezondheidszorg en welzijn en het onderwijs scoren goed. Binnen de techniek en ICT en het onderwijs worden voor alle onderliggende opleidingen goede perspectieven verwacht voor de komende zes jaar. Voor de techniek opleidingen elektrotechniek en werktuigbouwkunde zijn de perspectieven zelfs zeer goed. De schaarste aan technisch geschoold personeel en werkenden met een onderwijsachtergrond op bachelor niveau blijft de komende zes jaar dus bestaan. Binnen de gezondheidszorg en welzijn, scoren nagenoeg alle opleidingen goed, waardoor de krapte in de zorg naar verwachting ook zal aanhouden. Een uitzondering hierop is de richting medische diagnostiek en medische technologie, die matig scoort. Voor de bachelor landbouw, wiskunde en natuurwetenschappen zijn de vooruitzichten ook goed. Zowel op bachelor als op masterniveau zal

57 UWV (2019). Factsheet ICT beroepen. https://www.uwv.nl/overuwv/kennis-cijfers-en-onderzoek/ arbeidsmarktinformatie/factsheet-arbeidsmarkt-ict-2019.aspx 
er met het oog op de toenemende vraag naar klimaat- en milieuvriendelijke materialen en productieprocessen in de toekomst steeds meer vraag zijn naar afgestudeerden in de biologie, biochemische wetenschappen, maar ook in de landbouw, en natuur- en scheikunde. De vooruitzichten voor de bachelor kunst, taal en cultuur zijn redelijk. Voor de bachelor taal en cultuur zijn de vooruitzichten redelijk en voor de bachelor kunst matig, wat aangeeft dat vraag en aanbod redelijk in evenwicht zijn voor de komende zes jaar. De bachelor economie en recht scoort matig. Over het algemeen zijn dit studies met een groot aantal studenten en dus met een grote verwachte instroom op de arbeidsmarkt, terwijl de vraag achter blijft. Voor de opleidingen economie en econometrie en financieel management en fiscaal recht binnen deze subsector gelden redelijke perspectieven, terwijl voor de overige opleidingen (management, bedrijfs- en personeelswetenschappen, marketing en public relations, en recht) matige perspectieven gelden. Tot slot gelden voor dienstverlening en journalistiek, gedrag en maatschappij slechte perspectieven, ook voor alle onderliggende opleidingen.

De masteropleidingen scoren over het algemeen gunstig. Voor techniek en ICT, gezondheidszorg, en onderwijs gelden goede perspectieven tot en met 2024. Naar verwachting houden de geldende tekorten in de techniek, de zorg en het onderwijs de komende jaren aan. Binnen de techniek en ICT zijn de arbeidsmarktperspectieven voor werktuigbouwkunde zelfs zeer goed. Voor de master landbouw, wiskunde en natuurwetenschappen zijn de prognoses voor landbouw, biologie en biochemische technologie matig, en voor wis-, schei-, natuurkunde en geologie redelijk. Zoals aangegeven bij de bachelor, is de verwachting dat de vraag naar werkenden met een landbouw, biologie, en biochemische wetenschappelijke achtergrond de komende jaren snel zal toenemen omdat er, binnen alle sectoren, steeds meer geld wordt geïnvesteerd in de verduurzaming van productieprocessen. Verdere investeringen zullen naar verwachting de krapte verder doen toenemen ${ }^{58}$. Een van de redenen waarom, vooral op master niveau, de prognoses nu nog niet op goed of zeer goed staan, is dat de instroom van deze studenten relatief aanzienlijk is, maar ook voor een groot deel bestaat uit buitenlandse studenten waarvan het maar de vraag is of zij zich ook aanbieden als werkenden op de Nederlandse arbeidsmarkt (zie ook tekstbox 2). De prognoses voor economie en recht, en kunst, taal en cultuur zijn redelijk. De vraag en het aanbod voor de komende zes jaar sluiten dus behoorlijk goed op elkaar aan. Binnen economie en recht zijn de prognoses voor recht goed, en voor economie en econometrie, en management en bedrijfs- en personeelswetenschappen redelijk. Binnen kunst, taal en cultuur geldt dat de vervangingsvraag redelijk groot is in vergelijking met de instroom waardoor de prognoses behoorlijk positief uitvallen. Binnen de subsector master journalistiek, gedrag en maatschappij geldt vooral voor communicatie en journalistiek dat de vraag heel beperkt is ten opzichte van de instroom.

58 Weterings, A., Bakens, J, Ivanova, O. \& Fouarge, D. (2019). Frictie op de arbeidsmarkt door de energietransitie: een modelverkenning. Den Haag: PBL/Maastricht: ROA 
TEKSTBOX 2.1 Buitenlandse studenten in het hoger onderwijs en de instroom op de arbeidsmarkt

Met de komst van de bachelor-masterstructuur en de invoering van veel Engelstalige studies in het hoger onderwijs, neemt het aantal buitenlandse studenten in Nederland ook toe. Voor de arbeidsmarktprognoses geldt dat de uitstroom van de gehele studentenpopulatie wordt meegenomen als instroom in het arbeidsmarktprognosemodel voor POA. Niet alle buitenlandse studenten bieden zich echter aan op de Nederlandse arbeidsmarkt. Dit zou betekenen dat voor studies met een grote omvang buitenlandse studenten, de instroom in het arbeidsmarktprognosemodel wordt overschat en de ITA daardoor minder gunstig is dan in de werkelijkheid het geval is. Zo zou bijvoorbeeld gelden dat de ITA van de master opleiding landbouw, biologie en biochemische technologie een stuk gunstiger is als de buitenlandse studenten niet meegerekend zouden worden als instroom op de arbeidsmarkt. Hetzelfde geldt voor de masteropleiding economie en econometrie. In 2020 wordt er door ROA verdiepend onderzoek gedaan naar de omvang van buitenlandse studenten in het hoger onderwijs en hun arbeidsparticipatie op de Nederlandse arbeidsmarkt na afronding van de studie en de invloed van deze groep op de instroomcomponent van het arbeidsmarktprognosemodel.

\subsection{Toekomstige knelpunten in de personeelsvoorziening naar beroep}

In de voorgaande paragraaf zijn de arbeidsmarktperspectieven van gediplomeerden besproken (ITA's), waarbij de afgeronde opleiding het uitgangspunt vormt. De ontwikkelingen die hieraan ten grondslag liggen, te weten de omvang van het aanbod van gediplomeerden op de arbeidsmarkt en de verwachte totale vraag, bestaande uit de uitbreidings- en vervangingsvraag, hebben ook hun weerslag op de arbeidsmarkt voor de verschillende beroepsgroepen. Bij het vervullen van baanopeningen voor een beroep, is de werkgever afhankelijk van het aanbod van instromers met een opleidingsachtergrond die de specifieke kennis en vaardigheden bieden die passen bij taken die uitgevoerd moeten worden in dat beroep. Het aanbod van gediplomeerden, bepaalt of werkgevers weinig of veel problemen zullen hebben om in de komende zes jaar voldoende geschikt personeel te vinden dat beschikt over de vereiste kwalificaties. Werkgevers die zoeken naar beroepsspecifieke expertise zullen de knelpunten moeilijker opgelost krijgen, omdat er weinig alternatieven zijn. Werkgevers die kunnen putten uit werkenden uit verschillende opleidingsachtergronden voor het vervullen van hun baanopeningen zullen waarschijnlijk gemakkelijker in hun personeelsbehoefte voorzien. Bij het opstellen van de prognoses wordt hiermee rekening gehouden.

De Indicator Toekomstige Knelpunten in de Personeelsvoorziening naar Beroep (ITKB) geeft inzicht in de wijze waarop de aansluitingsproblematiek tussen onderwijs en arbeidsmarkt van invloed is op de wervingsproblematiek in de verschillende beroepsgroepen. De ITKB geeft de kans aan dat de vraag vanuit een bepaalde beroepsgroep in de gewenste opleidingssamenstelling vervuld kan worden, rekening houdend met de vraag-aanbod- 
verhoudingen voor de verschillende opleidingstypen. ${ }^{59}$ Deze indicator heeft een waarde tussen o en 1. Naarmate de indicator lager is, zijn de knelpunten groter voor de werving vanuit de opleidingscategorieën die voor de betreffende beroepsgroepen relevant zijn. Bij een score die dichter bij 1 ligt, zullen werkgevers in de komende jaren minder moeite hebben om de gewenste personeelssamenstelling te realiseren.

Inzicht in de knelpunten naar beroep is voor verschillende gebruikers en gebruiksdoelen van belang. Allereerst formuleren werkgevers de behoefte aan nieuw personeel in bijvoorbeeld vacatures, vaak primair in termen van functiecategorieën of beroepen. Zij zijn immers op zoek naar iemand die bepaalde taken - gebundeld in een bepaalde beroepen - binnen de organisatie kan vervullen. Voor werkgevers kan inzicht in de knelpunten naar beroepsgroep dus van belang zijn voor hun wervings- en personeelsbeleid. Daarnaast kunnen (langdurige) werklozen of werkenden die op zoek zijn naar een andere werkkring gebruik maken van de informatie over de knelpunten in de personeelsvoorziening naar beroep in hun oriëntatie naar een nieuwe of andere werkkring. Nauw samenhangend met het tweede gebruiksdoel, zijn de bij- en omscholingsprogramma's, omdat deze doorgaans gericht zijn op een bepaald beroep. Inzicht in de knelpunten naar beroep kan als leidraad dienen bij het vormgeven en inrichten van dergelijke scholingsprogramma's.

Tabel 2.2 geeft de verwachte knelpunten in de personeelsvoorziening voor werkgevers naar beroepsklassen weer voor de periode 2019-2024. De laatste twee kolommen van de tabel laten het percentage van de vraag zien waarvoor werkgevers (vrijwel) geen of (zeer) grote knelpunten kunnen verwachten. De percentages zijn gebaseerd op de typeringen van de knelpunten van de beroepsgroepen die samen een beroepsklasse vormen (zie Bijlage B).

Veruit de grootste knelpunten voor werkgevers tot 2024 worden verwacht in de personeelsvoorziening van zorg en welzijn beroepen; voor alle onderliggende beroepen gelden grote tot zeer grote knelpunten door een grote vraag. Ook voor ICT-beroepen geldt dat voor meer dan $80 \%$ van de onderliggende vraag grote tot zeer grote knelpunten worden verwacht. Dit geldt dan voornamelijk voor de (hoger geschoolde) beroepen zoals software- en applicatieontwikkelaars en databank- en netwerkspecialisten en minder voor gebruikersondersteuning ICT en radio- en televisietechnici waarvoor de markt ruimer is.

Voor pedagogische en technische beroepen worden ook grote knelpunten in de personeelsvoorziening verwacht, maar niet voor alle onderliggende beroepen. Het gaat voornamelijk om leerkrachten in het basisonderwijs (zeer groot) en andere docenten (groot). Werkgevers die vakspecialisten natuur en techniek, zoals technici bouwkunde en natuur, en productieleiders industrie en bouw, bouwarbeiders, en elektriciens en elektromon-

59 Hierbij is rekening gehouden met het verwachte aanbod van scholieren op zoek naar een bijbaan. Dit aanbod heeft vooral effect op de verwachte knelpunten in lage functies zoals vakkenvullers; deze worden kleiner. 
teurs zoeken, moeten rekening houden met grote knelpunten. Ook voor bijna alle onderliggende beroepen (behalve biologen en natuurwetenschappers) in het segment ingenieurs en onderzoekers wiskunde-, natuur-, en technische wetenschappen, worden zeer grote knelpunten verwacht. Voor deze beroepen geldt dat de instroom niet voldoende is om aan voornamelijk de vervangingsvraag te voldoen. Een mogelijke verklaring hiervoor is dat een deel van instroom 'weglekt' naar andere, niet-technische beroepen ${ }^{60}$, omdat er buiten de techniek de vraag naar analytische en probleemoplossende vaardigheden hoog is ${ }^{61}$, en deze vaardigheden zijn waar technisch opgeleiden hoog op scoren. Een andere mogelijke verklaring is dat een deel van de technische opleidingen minder 'harde' opleidingen betreft die kwalitatief minder goed aansluiten bij de vraag van werkgevers in de technische sector. Voor het segment metaalarbeiders en machinemonteurs geldt dat er tot 2024 grote knelpunten worden voorspeld voor automonteurs en machinemonteurs, maar minder grote knelpunten voor metaalbewerkers en constructiewerkers, en lassers en plaatwerkers. Wij concluderen dan ook dat aan de beroepenkant de huidige knelpunten in de personeelsvoorziening voor pedagogische, zorg en welzijn en technische en ICT-beroepen de komende zes jaar zullen aanhouden.

Werkgevers zullen naar verwachting (vrijwel) geen knelpunten in de personeelsvoorziening ondervinden voor commerciële beroepen, zoals verkopers, voor transport en logistiek beroepen, zoals hulpkrachten transport en logistiek, en voor dienstverlenende beroepen, zoals schoonmakers en keukenhulpen. Binnen de creatieve en taalkundige beroepen gelden wel zeer grote knelpunten voor auteurs en taalkundigen, en grote knelpunten voor bibliothecarissen en conservatoren en beeldend kunstenaars, allemaal omdat de uitbreidingsvraag relatief hoog is. Merk echter op dat voor veel van deze beroepen geldt dat het aandeel zelfstandigen relatief hoog en de beloning relatief laag is. Binnen het beroepssegment auteurs en kunstenaars worden geen knelpunten verwacht voor uitvoerend kunstenaars en journalisten. Ook onder de bedrijfseconomische en administratieve beroepen verwachten we over het algemeen weinig knelpunten in de personeelsvoorziening. Binnen deze beroepsgroep verwachten we alleen grote knelpunten voor bedrijfskundigen en organisatieadviseurs.

60 Zie Fouarge, D., J. Bakens, en I. Bijlsma (2018). Aansluiting Technisch Onderwijs en de Arbeidsmarkt, ROA Technical Reports no. 006, Maastricht: Research Centre for Education and the Labour Market.

61 Fouarge, D. (2017). Veranderingen in werk en vaardigheden. Oratie, Maastricht University. 
TABEL 2.2 Toekomstige knelpunten in de personeelsvoorziening naar beroep (ITKB) voor werkgevers, en percentage van vraag met (vrijwel) geen en (zeer) grote knelpunten (naar ITKB-typering), 2019-2024

\begin{tabular}{|l|l|l|c|c|}
\hline & ITKB & ITKB-typering & $\begin{array}{c}\text { \% geen } \\
\text { knelpunten }\end{array}$ & $\begin{array}{c}\text { \% grote } \\
\text { knelpunten }\end{array}$ \\
\hline Pedagogische beroepen & 0,842 & groot & 35 & 65 \\
\hline Creatieve en taalkundige beroepen & 0,874 & enige & 25 & 42 \\
\hline Commerciële beroepen & 0,924 & vrijwel geen & 100 & 0 \\
\hline Bedrijfseconomische en administratieve beroepen & 0,906 & vrijwel geen & 66 & 8 \\
\hline Managers & 0,859 & groot & 3 & 54 \\
\hline Openbaar bestuur, veiligheid en juridische beroepen & 0,859 & groot & 22 & 56 \\
\hline Technische beroepen & 0,839 & groot & 10 & 64 \\
\hline ICT-beroepen & 0,838 & groot & 6 & 82 \\
\hline Agrarische beroepen & 0,876 & enige & 16 & 56 \\
\hline Zorg en welzijn beroepen & 0,835 & zeer groot & 0 & 100 \\
\hline Dienstverlenende beroepen & 0,923 & vrijwel geen & 96 & 0 \\
\hline Transport en logistiek beroepen & 0,928 & geen & 100 & 0 \\
\hline Totaal (incl. overig) & & & 47 & 39 \\
\hline Bron: ROA(AIS) & & & \\
\hline
\end{tabular}

Bron: $\operatorname{ROA}(\mathrm{AIS})$

Binnen de agrarische beroepen worden enige knelpunten verwacht, voornamelijk gedreven door grote knelpunten voor land- en bosbouwers en hoveniers, tuinders en kwekers. Dit komt voornamelijk door een lage instroom voor deze beroepen. Net zoals in de prognoses tot 2022, worden ook tot 2024 grote knelpunten verwacht in de personeelsvoorziening van managers. Onder de managers valt een hele diverse groep beroepen, en ook een heel diverse groep werkenden wat opleidingsachtergrond betreft. Een gedeelte van deze knelpunten kan verklaard worden uit het feit dat een aanzienlijk percentage van de managers werkzaam is in sectoren waar knelpunten worden verwacht, zoals het onderwijs, de ICT of de zorg. Het gaat vaak om managers met een opleidingsachtergrond waarvoor de ITA's ook gunstig zijn. Het is dus moeilijker managers met een geschikte opleidingsachtergond te vinden voor de beschikbare baanopeningen in deze beroepsgroep.

Tot slot zijn de grootste knelpunten voor openbaar bestuur, veiligheid en juridische beroepen te vinden bij politie en brandweer, politie-inspecteurs, militairen, juristen en overheidsbestuurders. Dit is mede te verklaren door de vergrijzing in deze beroepen, en voor overheidsbestuurders en politie-inspecteurs door overheidsinvesteringen die resulteren in een relatief grote uitbreidingsvraag. 


\subsection{Aanpassingsmechanismen op de arbeidsmarkt}

In de vorige paragrafen is een beeld geschetst van de verwachte ontwikkelingen in vraag en aanbod op de arbeidsmarkt naar opleidingstypes en naar beroepen. Bij een disbalans tussen vraag en aanbod kunnen verschillende aanpassingsmechanismen in werking treden. Zo liet figuur 1.10 zien dat bij veranderingen in de vraag bij hoogopgeleiden vooral sprake is van aanpassingen van het loonniveau, terwijl bij laagopgeleiden zowel sprake is van aanpassingen in loonniveau als van aanpassingen in termen van de participatiegraad. Dat de participatiegraad van hoogopgeleiden nauwelijks verandert met veranderingen in de conjunctuur, kan te maken hebben met het feit dat zij ook banen kunnen accepteren onder hun niveau, terwijl dit voor lager opgeleiden nauwelijks mogelijk is. In deze paragraaf gaan wij in op een aantal indicatoren van de aansluiting tussen onderwijs en arbeidsmarkt naar opleidingstypes die indicatief zijn voor de aanpassingsmechanismen die op gang kunnen komen bij een disbalans tussen de vraag naar en het aanbod van arbeid. We bespreken een vijftal indicatoren 1) de kans op werkloosheid, 2) het werken in een kleine deeltijdbaan (20 uur of minder), 3) de onderbenutting (werk onder het eigen niveau), 4) werken buiten de eigen richting en 5) het precentage van de werkenden met een loon onder het gemiddelde voor het opleidingsniveau. De aanpassingen op de arbeidsmarkt zullen bij een disbalans tussen vraag en aanbod verschillen tussen opleidingsrichtingen. Bij opleidingen gericht op vaardigheden in zeer specifieke beroependomeinen zal het bij een overaanbod bijvoorbeeld lastiger zijn om een baan te vinden buiten het eigen domein dan bij bredere opleidingen, waardoor werkloosheid eerder zal optreden. Een ander voorbeeld: op internationaal concurrerende markten is het bij krapte voor werkgevers lastiger om de lonen te laten stijgen om arbeidskrachten aan te trekken, waardoor zij eerder zullen werven onder gediplomeerden uit aanverwante richtingen. Het is belangrijk om op te merken dat deeltijd werk niet per se duidt op een slechte arbeidsmarktpositie. Voor veel werknemers, bijvoorbeeld vrouwen, kan dit ook een vrijwillige keuze zijn. Het valt dan ook op dat beroepen die zich kenmerken door een hoge mate van deeltijdwerken, vaak ook beroepen zijn met een hoog aandeel vrouwen. Hier wordt er gemakshalve vanuit gegaan dat een voltijdbaan 'beter' is dan een kleine baan van 20 uur of minder.

Om een zinnige vergelijking te kunnen maken tussen de verschillende indicatoren, moeten de indicatoren eerst vergelijkbaar gemaakt worden. In deze paragraaf wordt voor iedere opleiding en iedere indicator de gestandaardiseerde Z-score berekend. De score van een bepaalde opleidingsrichting op een bepaald terrein wordt berekend door de gemiddelde score van het opleidingsniveau af te trekken van de gemiddelde score van de opleidingsrichting binnen dat opleidingsniveau, en vervolgens te delen door de standaarddeviatie. De achterliggende data is te vinden in Bijlage E. De resultaten worden voor elk opleidingsniveau gepresenteerd in een spindiagram, waardoor de resultaten voor de verschillende richtingen eenvoudig te vergelijken zijn. Een waarde van o in het web houdt in dat de score van een opleidingsrichting op de betreffende indicator overeenkomt met de gemiddelde score op die indicator van alle gediplomeerden binnen dat opleidingsniveau. Voor alle indicatoren geldt dat hoe dichter de score van een oplei- 
dingscategorie bij de kern van het spindiagram ligt, des te beter de aansluiting van de gediplomeerden op de arbeidsmarkt is. Een score verder weg van de kern duidt op een minder goede aansluiting.

FIGUUR 2.1 Combinatie van aansluitingsindicatoren, gediplomeerden mbo 2-opleidingen mbo 2

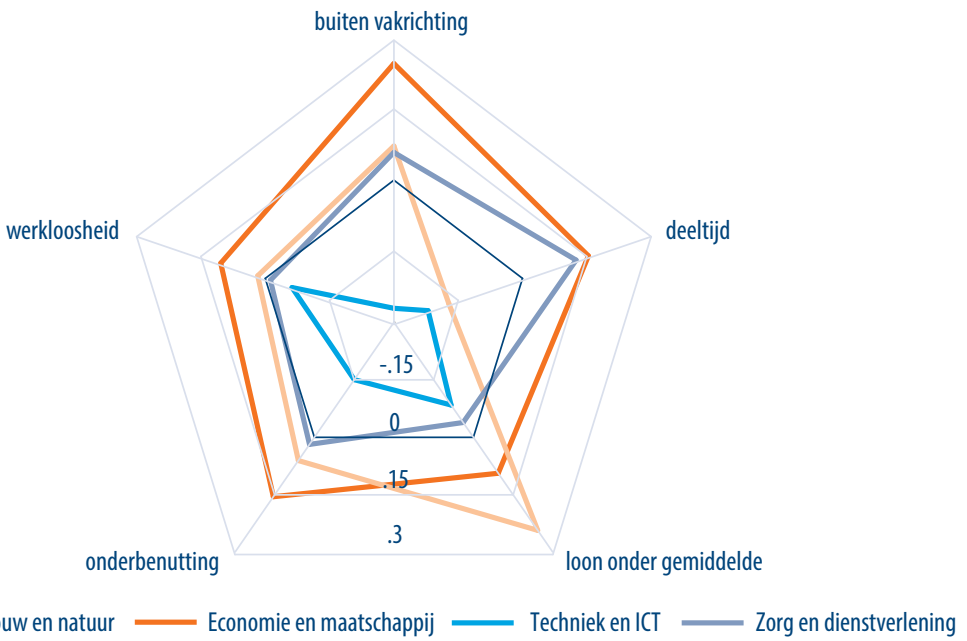

Bron: ROA (AIS)

Figuur 2.1 geeft voor gediplomeerden van mbo 2-opleidingen per opleidingssector de scores op de vijf besproken aansluitingsindicatoren weer. Duidelijk is te zien dat afgestudeerden van mbo 2 techniek en ICT op alle vijf de terreinen het beste scoren, wat in lijn is met de huidige krapte op de arbeidsmarkt voor technisch geschoolden. Echter, onze prognoses voor de komende zes jaar zijn pessimistischer. De andere opleidingen die het relatief goed doen zijn mbo 2 zorg en dienstverlening en mbo 2 landbouw en natuur. Zowel de werkloosheid, onderbenutting en werken buiten de richting wijken niet erg af van de verwachtingswaarde (de nullijn). Voor mbo z'ers met een achtergrond in de zorg en dienstverlening geldt dat het loon iets bovengemiddeld is, terwijl het loon voor mbo z'ers met een achtergrond in landbouw en natuur ver onder het gemiddelde ligt. Deeltijdwerken komt in de zorg op dit niveau veel voor, en dat laat figuur 2.1 ook zien. Mbo 2 economie en maatschappij heeft de minst gunstige arbeidsmarktperspectieven en dat blijkt ook uit de mate waarin werkenden met deze achtergrond buiten de richting werk vinden, kleinere banen hebben, werkloos zijn of beneden het opleidingsniveau werken. 
FIGUUR 2.2 Combinatie van aansluitingsindicatoren, gediplomeerden mbo 3-opleidingen

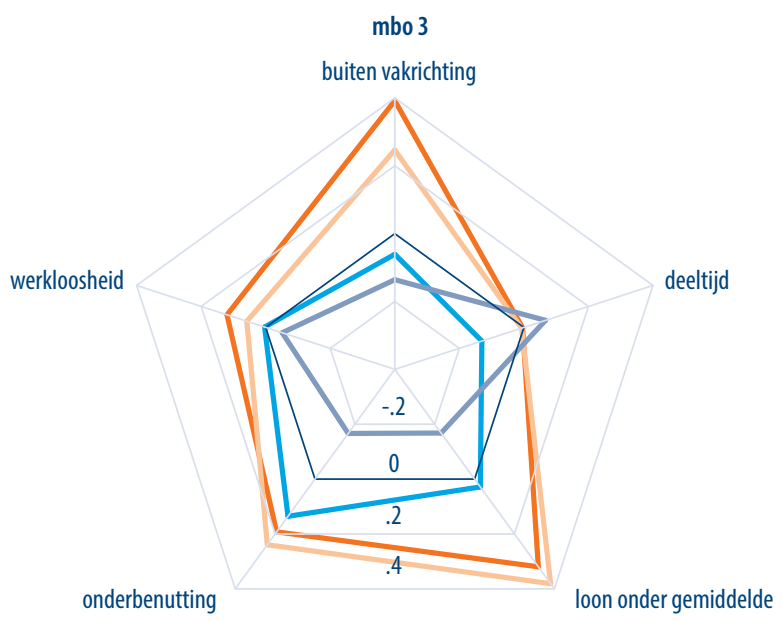

Landbouw en natuu Economie en maatschappij Techniek en ICT Zorg en dienstverlening

Bron: ROA (AIS)

Op mbo 3-niveau zien we een iets ander beeld dan op mbo 2-niveau, zoals weergegeven in figuur 2.2. De beste arbeidsmarktperspectieven zijn er voor de mbo 3-gediplomeerden met een zorg en dienstverlening achtergrond, en relatief gemiddelde arbeidsmarktperspectieven zien we voor mbo 3-gediplomeerden met een technische en ICT-achtergrond. Gediplomeerden met een mbo 3 techniek en ICT-achtergrond werken iets vaker onder hun niveau. Voor mbo 3-gediplomeerden met een economie en maatschappij of een landbouw en natuur achtergrond geldt dat de minder gunstige arbeidsmarkperspectieven vooral tot uiting komen in een laag loon en in het vinden van een baan buiten de eigen richting.

In figuur 2.3 worden de vijf aansluitingsindicatoren voor mbo 4-opleidingen belicht. In grote lijnen is het beeld vergelijkbaar met mbo 3: ook hier komt naar voren dat afgestudeerden van de richtingen techniek en ICT, en zorg en dienstverlening er beter voor staan, en de afgestudeerden van de richtingen landbouw en natuur, en economie en maatschappij een stuk minder. Wel is de werkloosheid en de deeltijdfactor voor mbo 4-gediplomeerden met een landbouw en natuur achtergrond gunstiger dan op mbo 3- niveau. 
FIGUUR 2.3 Combinatie van aansluitingsindicatoren, gediplomeerden mbo 4-opleidingen mbo 4

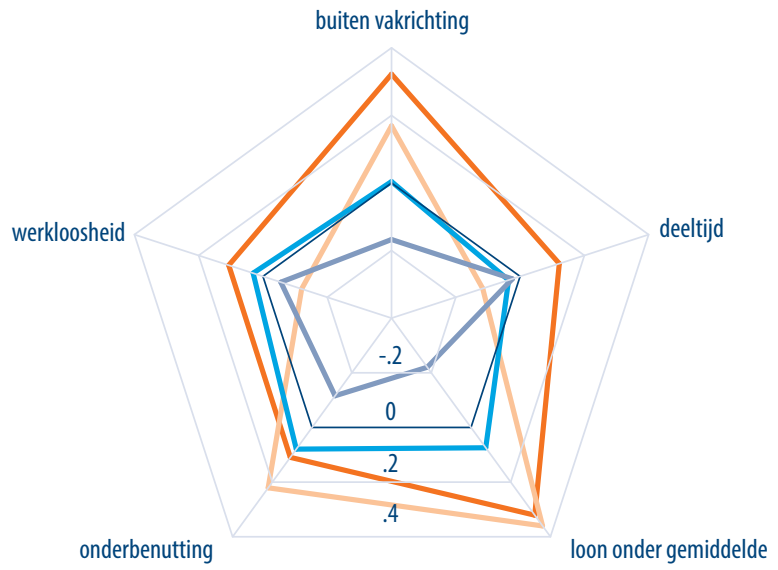

onderbenutting

loon onder gemiddelde

Landbouw en natuur _ Economie en maatschappij Techniek en ICT Zorg en dienstverlening

Bron: ROA (AIS)

Voor de afgestudeerden met een hbo- en wo-bachelor is over het geheel genomen de aansluiting onderwijs-arbeidsmarkt het best voor gediplomeerden uit de richtingen techniek: op alle vijf de indicatoren scoren ze beter dan gemiddeld (figuur 2.4). Omdat de prognoses ook gunstig uitvallen voor bachelor gediplomeerden in de techniek en ICT verwachten wij dat de aansluiting ook de komende jaren gunstig zal uitvallen. Het valt echter op dat de lonen nauwelijks stijgen ondanks de heersende krapte. ${ }^{62}$ Ook afgestudeerden met een bachelor achtergrond in zorg en onderwijs hebben goede aansluitingsindicatoren, vooral als het gaat om het vinden van werk binnen de eigen vakrichting. Met name voor zorg en welzijn gediplomeerden komt echter het werken in kleine deeltijdbanen en onder het eigen niveau vaker voor. De arbeidsmarktindicatoren zijn minder gunstig voor werkenden met een bachelor landbouw en natuur, en economie en maatschappij. Vooral afgestudeerden met een bachelor economie en maatschappij geven relatief vaak aan werk buiten de eigen vakrichting te vinden. Dit wijst op een ruime arbeidsmarkt, maar kan ook gunstig zijn als dit leidt tot minder werkloosheid onder afgestudeerden met deze achtergrond omdat ze breder inzetbaar zijn op de arbeidsmarkt.

62 Fouarge, D, J. Bakens en I. Bijlsma (2018). Aansluiting Technisch Onderwijs en de Arbeidsmarkt, ROA Technical Report no. 006. https://cris.maastrichtuniversity.nl/portal/en/publications/aansluiting-technisch-onderwijsen-de-arbeidsmarkt(626559fc-fca1-4bb4-9038-b369fd4eb9a2).html 
FIGUUR 2.4 Combinatie van aansluitingsindicatoren, gediplomeerden bacheloropleidingen

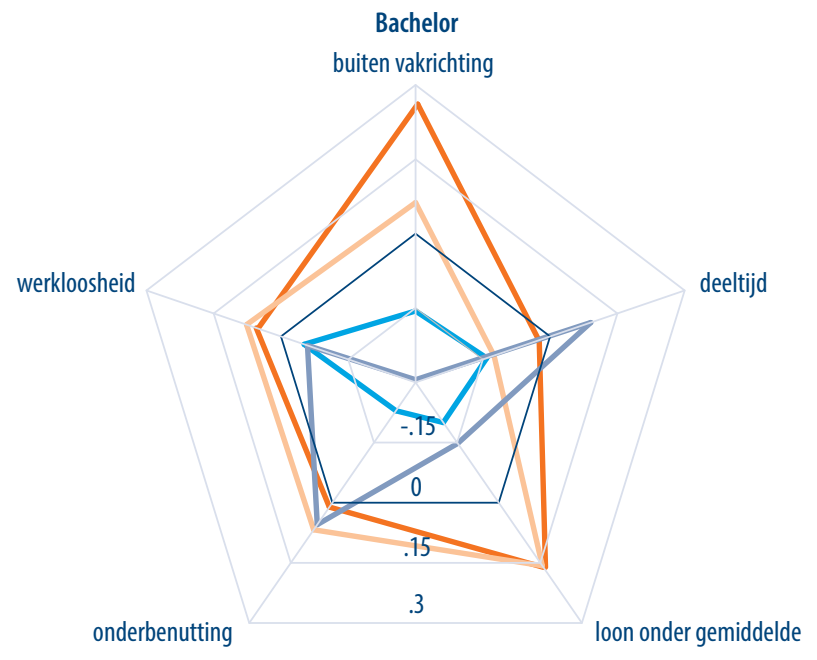

Landbouw en natuur

Economie en maatschappij

Techniek en ICT

Zorg en onderwijs

Bron: ROA (AIS)

FIGUUR 2.5 Combinatie van aansluitingsindicatoren, gediplomeerden masteropleidingen

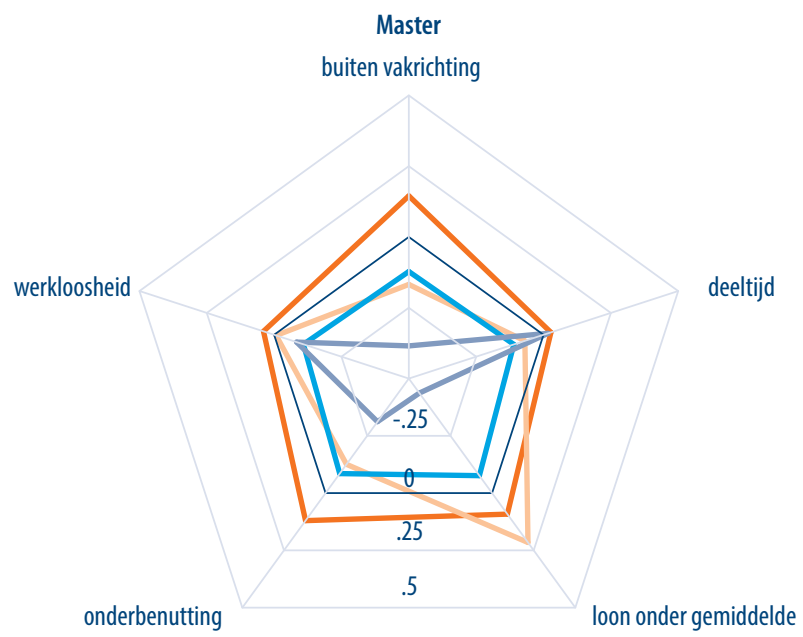

Landbouw en natuu

Economie en maatschappij Techniek en ICT

Zorg en onderwijs

Bron: ROA (AIS) 
Op masterniveau zijn de meest gunstige indicatoren voor zorg en onderwijs (figuur 2.5). Het werken in kleine deeltijdbanen ligt hier wel hoger dan bij andere opleidingen. Dit houdt mogelijk verband met het relatief grote aandeel vrouwen in deze sector. Ook de afgestudeerden binnen de master techniek en ICT hebben gunstige aansluitingsindicatoren. Voor landbouw en natuur zijn de aansluitingsindicatoren voor master gediplomeerden ook niet slecht, maar het loon blijft ver achter bij het gemiddelde. De minst gunstige aansluitingsindicatoren gelden voor de master economie en maatschappij, die op 4 van de 5 indicatoren het slechtste scoort. Binnen de master zijn de aansluitingsindicatoren over het algemeen gunstig voor alle richtingen in vergelijking met andere opleidingsniveaus.

\subsection{Conclusie}

Vraag en aanbod op de arbeidsmarkt zijn bepalend voor de arbeidsmarktpositie van gediplomeerden. Wanneer de vraag naar personeel met een bepaalde opleidingsachtergrond het aanbod overstijgt, ontstaat er krapte op de arbeidsmarkt en zullen gediplomeerden met deze opleidingsachtergrond weinig moeite hebben bij het vinden van een passende baan. Voor werkgevers geldt dan juist dat zij meer moeite zullen ervaren bij het werven van personeel. Blijft de vraag achter bij het aanbod, dan leidt dit tot een ruime arbeidsmarkt en daarmee tot slechte arbeidsmarktvooruitzichten voor de nieuwe instroom op de arbeidsmarkt. Slechte arbeidsmarktperspectieven zullen zich over het algemeen uiten in meer werkloosheid, lagere lonen, het moeten accepteren van werk onder het eigen niveau of buiten de eigen richting, slechte arbeidsvoorwaarden, etc.

Alhoewel de economische groei stabiliseert, blijven de vooruitzichten voor recent gediplomeerden over het algemeen gunstig voor de periode 2019-2024. Over het algemeen geldt dat hoe hoger het opleidingsniveau van gediplomeerden, hoe beter hun arbeidsmarktperspectieven. Zo zijn de arbeidsmarktperspectieven voor gediplomeerden met een bachelor- of masterachtergrond over het algemeen goed. Er zijn duidelijke tekenen van krapte voor gediplomeerden uit de gezondheidszorg- en welzijnopleidingen, het onderwijs, en voor technisch en ICT-opgeleiden (op bachelor- en masterniveau). Voor gediplomeerden uit de zorg zijn de goede perspectieven zowel het gevolg van uitbreidingsvraag als ook een toenemende vervangingsvraag. Gediplomeerden uit technische opleidingen gaan ook een gunstige ontwikkeling van de vraag tegemoet, niet alleen in de technische sector; in toenemende maten zijn technisch geschoolden werkzaam in andere beroepen dan technische beroepen.

Toekomstige ontwikkelingen in vraag en aanbod zijn ook bepalend voor de personeelswerving door werkgevers. De verwachte knelpunten in de personeelsvoorziening voor werkgevers zijn het grootst in zorg en welzijn, de ICT- en technische beroepen, en in het onderwijs. Er wordt verwacht dat werkgevers grote moeite zullen hebben om leerkrachten in het basisonderwijs te vinden. De knelpunten in de zorg hebben zowel betrekking op de hogere functies op bachelor- en masterniveau, maar ook op verpleegkunde op mbo-niveau. De markt is duidelijk ruimer voor commerciële en bedrijfsecono- 
mische en administratieve beroepen (wellicht als gevolg van automatisering), en voor agrarische beroepen (als gevolg van de structurele krimp). 


\section{3 \\ ONTWIKKELINGEN IN VRAAG EN AANBOD 2019-2024}

\subsection{Inleiding}

De kernindicatoren voor de verwachte aansluiting tussen vraag naar en aanbod van arbeid tot 2024 (ITA en ITKB) werden besproken in hoofdstuk 2. De ramingen uit het ROA arbeidsmarktprognosemodel voor vraag en aanbod voor de komende zes jaar zijn bepalend voor de waarde van deze indicatoren. In dit hoofdstuk bespreken wij deze ramingen. Voor de prognoseperiode van 2019 tot 2024 bespreken we voor de vraagzijde de uitbreidingsvraag, vervangingsvraag en de baanopeningen Voor de aanbodzijde bespreken wij de arbeidsmarktinstroom van gediplomeerden. Deze componenten gezamenlijk helpen om de verwachte ontwikkelingen in de spanningsindicatoren te begrijpen. In paragraaf 3.2 komt de prognose voor de uitbreidingsvraag aan bod voor 12 beroepsklassen en 33 opleidingssubsectoren. Deze geeft de veranderingen in de werkgelegenheid weer. Paragraaf 3.3 bespreekt de verwachte vervangingsvraag naar beroep en opleiding en wordt bepaald door het (tijdelijk) verlaten van de arbeidsmarkt door migratie, arbeidsongeschiktheid, werkloosheid, (vervroegd) pensioen, kinderzorg, of een vervolgopleiding. Samen met de positieve uitbreidingsvraag, bepaalt de vervangingsvraag het totaal aantal baanopeningen (een negatieve uitbreidingsvraag krimp- leidt immers niet tot vacatures). Hier gaan we dieper op in, in paragraaf 3.4. Ten slotte, focussen we in paragraaf 3.5 op het verwachte aanbod op de arbeidsmarkt, of de instroom van gediplomeerden. Paragraaf 3.6 concludeert.

\subsection{Uitbreidingsvraag}

Een positieve uitbreidingsvraag in de periode 2019-2024 duidt op een toename van de werkgelegenheid (baancreatie) voor de desbetreffende beroepsklasse of opleidingscategorie, en een negatieve uitbreidingsvraag duidt op een krimp van de werkgelegenheidsdaling (baanvernietiging).

\section{Uitbreidingsvraag naar beroep}

Tabel 3.1 toont de verwachte uitbreidingsvraag in personen en percentages voor de 12 onderscheiden beroepsklassen voor de periode 2019-2024. Voor de Nederlandse 
arbeidsmarkt in zijn geheel wordt een uitbreidingsvraag van 464.700 werkenden voorspeld. Dit komt neer op een groei van $0,9 \%$ per jaar ( $6 \%$ over 6 jaar) ten opzichte van het aantal werkenden in 2018. De groei in de vraag naar arbeid als gevolg van economische groei ligt bijna 1\%-punt lager tot en met 2024 dan in de prognoses tot en met 2022. Veruit de grootste uitbreidingsvraag wordt geschat voor zorg en welzijn beroepen met $14 \%$ tot en met 2024. De vraag naar zorg en welzijn beroepen is verantwoordelijk voor bijna een derde van de totale verwachte uitbreidingsvraag. Ook de vraag naar nieuwe werkkrachten in creatieve en taalkundige beroepen, managers, en ICT-beroepen is relatief groot. Voor agrarische beroepen wordt als enige beroepsklasse geen groei in de vraag naar nieuwe werkkrachten verwacht tot en met 2024.

TABEL 3.1 Uitbreidingsvraag naar beroepsklasse, in aantallen en als percentage van de werkgelegenheid in 2018, prognose 2019-2024

\begin{tabular}{|l|c|c|c|}
\hline & Aantal (6 jr.) & Totaal $(6 \mathrm{jr}$.) \% & Gem. jaarlijks \% \\
\hline Pedagogische beroepen & 11.700 & 2 & 0,3 \\
\hline Creatieve en taalkundige beroepen & 22.100 & 10 & 1,6 \\
\hline Commerciële beroepen & 18.000 & 2 & 0,3 \\
\hline Bedrijseconomische en administratieve beroepen & 59.900 & 4 & 0,6 \\
\hline Managers & 34.800 & 8 & 1,3 \\
\hline Openbaar bestuur, veiligheid en juridische beroepen & 10.200 & 3 & 0,6 \\
\hline Technische beroepen & 69.700 & 6 & 0,9 \\
\hline ICT-beroepen & 29.800 & 8 & 1,3 \\
\hline Agrarische beroepen & -500 & 0 & 0,0 \\
\hline Zorg en welzijn beroepen & 171.800 & 14 & 2,2 \\
\hline Dienstverlenende beroepen & 31.300 & 4 & 0,6 \\
\hline Transport en logistiek beroepen & 22.300 & 4 & 0,6 \\
\hline Totaal (incl. overig) & 464.700 & 5 & 0,9 \\
\hline
\end{tabular}

Bron: ROA (AIS)

Hierna worden kort de prognoses van de uitbreidingsvraag van de 12 afzonderlijke beroepsklassen besproken en wordt bovendien ingegaan op enkele opvallende ontwikkelingen binnen de onderliggende beroepsgroepen.

Voor de pedagogische beroepen wordt een gemiddelde jaarlijkse uitbreidingsvraag verwacht van $0,3 \%$. De groei in pedagogische beroepen is onder andere afhankelijk van demografische ontwikkelingen. Door de daling van de geboortecijfers staat de groei in het aantal scholieren onder druk, wat zich vertaalt in een lage uitbreidingsvraag voor nagenoeg alle onderliggende beroepsgroepen. De totale uitbreidingsvraag voor docenten ligt ongeveer op $2 \%$ tot en met 2024. Voor leidsters kinderopvang en onderwijsassistenten ligt de totale uitbreidingsvraag hoger, op $5 \%$, mogelijk om werkdruk in het onderwijs tegen te gaan. 
De voorziene werkgelegenheidsgroei van de creatieve en taalkundige beroepen is met $10 \%$ tot en met 2024 een van de hoogste. Er is een extra vraag naar auters en taalkundigen van in totaal $18 \%$, maar ook voor bibliothecarissen en conservatoren, beeldend kunstenaars, en fotografen en interieurontwerpers is er een uitbreidingsvraag van in totaal $14 \%$. De groeiende vraag naar deze beroepen zou mogelijk samen kunnen hangen met de toenemende vraag naar creatieve vaardigheden op de arbeidsmarkt die tot nog toe moeilijk te automatiseren zijn. De laagste uitbreidingsvraag binnen deze beroepsklasse is voor journalisten, met een totale extra vraag van 3\% tot en met 2024 .

Voor commerciële beroepen ligt de verwachte uitbreidingsvraag relatief laag, op gemiddeld 0,3\% per jaar, wat ver onder de gemiddelde prognose voor de totale arbeidsmarkt ligt. Binnen de beroepsklasse is geen grote variatie in de uitbreidingsvraag van de verschillende beroepsgroepen. Echter, vertegenwoordigers en inkopers scoren slecht met een verwachte krimp in de werkgelegenheid van $5 \%$ tot en met 2024. Voor verkoopmedewerkers detailhandel ligt de verwachte uitbreidingsvraag net iets hoger dan gemiddeld, met $4 \%$ groei tot en met 2024 .

De stijgende vraag naar zorg vertaalt zich ook in een grote uitbreidingsvraag voor zorg en welzijn beroepen tot 2024 van gemiddeld 2,2\% per jaar. Voor alle onderliggende beroepsgroepen wordt een positieve groei in het aantal werkenden verwacht. De uitbreidingsvraag is het hoogste voor artsen (2,1\% per jaar), gespecialiseerde verpleegkundigen ( $2,4 \%$ per jaar), fysiotherapeuten ( $2,4 \%$ per jaar), sociaal werkers, groeps- en woonbegeleiders $(2,9 \%$ per jaar), en verzorgenden $(3,0 \%$ per jaar). Ook voor mboverpleegkundigen is sprake van een positieve uitbreidingsvraag (1,5\% per jaar).

Voor bedrijfseconomische en administratieve beroepen wordt een uitbreidingsvraag van $4 \%$ tot 2024 verwacht, wat lager is dan gemiddeld voor alle beroepen. Binnen deze beroepsklasse bestaat echter een grote variatie van de prognoses naar beroepsgroepen. Een positieve groei wordt bijvoorbeeld verwacht voor bedrijfskundigen en organisatieadviseurs ( $0,9 \%$ per jaar), boekhouders ( $1,5 \%$ per jaar), zakelijke dienstverleners $(1,4 \%$ per jaar), en directiesecretaresses ( $1,5 \%$ per jaar). Voor beleidsadviseurs wordt een krimp in het aantal werkenden verwacht ( $0,1 \%$ per jaar), en ook voor financieel specialisten en economen wordt nauwelijks groei verwacht ( $0,1 \%$ per jaar). De grotere uitbreidingsvraag voor directiesecretaresses kan duiden op skills-upgrading binnen het secretaresseberoep.

De uitbreidingsvraag voor managers wordt geschat op gemiddeld 1,3\% per jaar, wat boven het gemiddelde van alle beroepen ligt. Opgemerkt moet worden dat de groep managers zeer heterogeen is qua samenstelling van de onderliggende beroepsspecialismen en opleidingsachtergronden. Opvallend is dat de grootse toename in de vraag naar managers verwacht wordt in sectoren die relatief conjunctuurgevoelig zijn. De grootste uitbreiding in de vraag wordt verwacht voor managers horeca ( $1,8 \%$ per jaar), managers detail- en groothandel (3,8\% per jaar) en managers commerciële en persoonlijke dienstverlening (4,2\% per jaar). 
De gemiddelde jaarlijkse uitbreidingsvraag voor openbaar bestuur, veiligheid en juridische beroepen wordt geschat op o,6\% per jaar. Voor de onderliggende beroepsgroepen geldt echter dat de verwachte groei in het aantal overheidsbestuurders, het aantal politie-inspecteurs, en bij politie en brandweermensen wel bovengemiddeld zal zijn, respectievelijk, 2,2\%, 1,7\%, en 1,2\% per jaar. Voor overheidsambtenaren wordt een kleine krimp verwacht van $0,1 \%$ per jaar.

De verwachte groei in de vraag naar technische beroepen tot 2024 is met 0,9\% per jaar gemiddeld te noemen. Deze beroepsklasse is echter wel zeer divers en de prognoses voor de onderliggende beroepsgroepen lopen dan ook erg uiteen. De grootste toename in het aantal werkenden wordt verwacht voor ingenieurs (geen elektrotechniek) (1,2\% per jaar), productieleiders industrie en bouw (1,3\% per jaar), bouwarbeiders ruwbouw (1,5\% per jaar), timmerlieden ( $1,5 \%$ per jaar), bouwarbeiders afbouw (1,8\% per jaar), loodgieters en pijpfitters ( $1,7 \%$ per jaar), schilders en metaalspuiters ( $2,4 \%$ per jaar), productcontroleurs ( $1,5 \%$ per jaar), electriciens en elektronicamonteurs ( $1,4 \%$ per jaar), en productiemachinebedieners ( $1,3 \%$ per jaar). Dit is dus een toename in de vraag naar beroepen gerelateerd aan bouwnijverheid, en omvat beroepen op mbo-, bachelor-, en masterniveau. Binnen de technische beroepen wordt er ook een krimp verwacht in het aantal biologen en natuurwetenschappers ( $0,2 \%$ per jaar), en elektrotechnisch ingenieurs ( $0,4 \%$ per jaar).

Voor de ICT-beroepen wordt met gemiddeld 1,3\% per jaar een relatief hoge vraag naar extra werkkrachten verwacht. De uitbreidingsvraag is hoog voor software- en applicatieontwikkelaars en voor gebruikersondersteuning ICT (beide 1,4\% per jaar). Voor databank- en netwerkspecialisten ligt de jaarlijkse uitbreidingsvraag iets lager $(1,2 \%)$. Voor radio- en televisietechnici ligt de uitbreidingsvraag een stuk lager binnen deze beroepsklasse (o,6\% per jaar).

De agrarische beroepen zijn de enige beroepen waarvoor krimp voorspeld wordt. Gedurende de prognoseperiode wordt namelijk een daling van het aantal werkenden verwacht van gemiddeld o,3\% over 6 jaar. De krimp geldt zowel voor land- en bosbouwers, als voor hoveniers, tuinders en kwekers en veetelers. Voor hulpkrachten in de landbouw wordt wel een uitbreiding van het aantal werkenden tot 2024 verwacht van $0,6 \%$ per jaar. Deze ramingen weerspiegelen de structurele krimp van de werkgelegenheid in de landbouwsector.

Voor de dienstverlenende beroepen wordt een jaarlijkse vraag naar nieuwe arbeidskrachten van gemiddeld $0,6 \%$ per jaar geraamd, iets lager dan het gemiddelde voor alle beroepen. De grootste toename wordt verwacht voor kappers en schoonheidsspecialisten ( $0,8 \%$ per jaar) en keukenhulpen ( $1,3 \%$ per jaar). De overige beroepsgroepen groeien allemaal rond $0,5 \%$ per jaar.

Tenslotte geven de prognoses aan dat ook het aantal personen dat werkzaam is binnen transport en logistieke beroepen de komende zes jaar zal toenemen met gemiddeld 
$0,3 \%$ per jaar. Dit geldt echter niet voor alle onderliggende beroepsgroepen. Een groei in het aantal werkenden wordt verwacht voor vrachtwagenschauffeurs (0,5\% per jaar), laders, lossers en vakkenvullers ( $1 \%$ per jaar), en vuilnisophalers en dagbladverzorgers $(1,2 \%$ per jaar). Een krimp in het aantal werkenden wordt echter verwacht voor dekofficieren en piloten ( $0,4 \%$ per jaar), chauffeurs auto's, taxi's en bestelwagens (-0,1\% per jaar), buschauffeurs en trambestuurders (-0,3\% per jaar), en bedieners mobiele machines (-o,1\% per jaar).

\section{Uitbreidingsvraag naar opleiding}

In het prognosemodel vormt de uitbreidingsvraag voor de verschillende beroepsgroepen de basis voor de uitbreidingsvraag naar opleidingstype. Bij de econometrische schatting van de uitbreidingsvraag naar opleidingstype wordt de zojuist besproken uitbreidingsvraag binnen de verschillende beroepsgroepen als input gebruikt: opleidingen krijgen uitbreidingsvraag toegerekend vanuit alle beroepsgroepen waarin deze te vinden zijn. In dit proces wordt expliciet rekening gehouden met eventuele verschuivingen in de samenstelling van opleidingen binnen beroepsgroepen over de tijd (bijvoorbeeld als gevolg van upgrading of downgrading). Zo kan het bijvoorbeeld voorkomen dat binnen een bepaalde beroepsgroep het aandeel werkenden met als opleidingstype wo techniek (sterk) toeneemt over de tijd.

Tabel 3.2 geeft de prognoses van de uitbreidingsvraag per opleidingscategorie voor de jaren 2019-2024 weer, zowel in aantallen personen als in groeipercentages ten opzichte van de werkgelegenheid in het basisjaar 2018. Door de nieuwe opleidingsclassificatie die sinds dit jaar wordt gehanteerd, is deze tabel echter moeilijk te vergelijken met die in de vorige versie van dit rapport. Voor alle opleidingssubsectoren wordt een positieve uitbreidingsvraag geschat tot 2024, en ook voor alle onderliggende opleidingstypen wordt een positieve uitbreidingsvraag verwacht. De uitbreidingsvraag is ook over de verschillende opleidingsniveaus redelijk gelijk verdeeld. Toch is er onderling nog grote variatie te zien.

Veruit de grootste uitbreidingsvraag wordt verwacht voor de opleidingen in de gezondheidszorg en welzijn, en dit voor alle opleidingsniveaus. Er wordt vooral een toename voorspeld van het aantal werkenden met een opleiding in de gezondheidszorg, zoals geneeskunde en tandheelkunde ( $1,9 \%$ per jaar), verpleegkunde en verloskunde ( $2,0 \%$ per jaar), verpleegkunde (mbo) (1,7\% per jaar), en verzorgende ig ( $2,0 \%$ per jaar), en in mindere mate voor opleidingen in de welzijnssector. 
TABEL 3.2 Uitbreidingsvraag naar opleidingssubsector, in aantallen en als percentage van de werkgelegenheid in 2018, prognose 2019-2024

\begin{tabular}{|c|c|c|c|}
\hline & Aantal (6 jr.) & Totaal (6 jr.) \% & Gem. jaarlijks \% \\
\hline mbo2 - economie en maatschappij & 5.500 & 4 & 0,6 \\
\hline mb02 - landbouw en natuur & 700 & 3 & 0,5 \\
\hline mb02 - techniek en ICT & 7.600 & 6 & 0,9 \\
\hline mb02 - zorg en dienstverlening & 13.100 & 8 & 1,2 \\
\hline mbo3 - economie en administratie & 3.900 & 5 & 0,8 \\
\hline mb03 - handel, ondernemerschap, transport en logistiek & 3.300 & 5 & 0,7 \\
\hline mb03 - voedsel, natuur en leefomgeving & 1.700 & 3 & 0,5 \\
\hline mb03 - ICT, media en vormgeving & 1.700 & 6 & 1 \\
\hline mb03 - techniek, bouw en procesindustrie & 10.500 & 5 & 0,9 \\
\hline mb03 - dienstverlening & 5.700 & 5 & 0,8 \\
\hline mb03 - gezondheidszorg en welzijn & 22.000 & 13 & 2 \\
\hline mbo4 - economie en administratie & 13.000 & 5 & 0,7 \\
\hline mb04 - handel, ondernemerschap, transport en logistiek & 5.600 & 4 & 0,6 \\
\hline mbo4 - voedsel, natuur en leefomgeving & 2.200 & 3 & 0,4 \\
\hline mb04 - ICT, media en vormgeving & 4.900 & 6 & 1 \\
\hline mb04 - techniek, bouw en procesindustrie & 14.800 & 5 & 0,8 \\
\hline mb04 - dienstverlening & 6.100 & 5 & 0,7 \\
\hline mb04 - gezondheidszorg en welzijn & 31.900 & 10 & 1,6 \\
\hline bachelor - dienstverlening & 4.700 & 4 & 0,6 \\
\hline bachelor - economie en recht & 21.900 & 4 & 0,7 \\
\hline bachelor - journalistiek, gedrag en maatschappij & 5.500 & 5 & 0,8 \\
\hline bachelor - kunst, taal en cultuur & 8.300 & 6 & 0,9 \\
\hline bachelor - landbouw, wiskunde en natuurwetenschappen & 2.700 & 4 & 0,6 \\
\hline bachelor - techniek en ICT & 17.900 & 6 & 0,9 \\
\hline bachelor - gezondheidszorg en welzijn & 37.600 & 10 & 1,6 \\
\hline bachelor - onderwijs & 10.400 & 4 & 0,6 \\
\hline master - economie en recht & 16.600 & 4 & 0,6 \\
\hline master - journalistiek, gedrag en maatschappij & 7.200 & 5 & 0,7 \\
\hline master - kunst, taal en cultuur & 5.300 & 5 & 0,8 \\
\hline master - landbouw, wiskunde en natuurwetenschappen & 4.500 & 4 & 0,7 \\
\hline master - techniek en ICT & 8.300 & 5 & 0,8 \\
\hline master - gezondheidszorg & 18.900 & 11 & 1,7 \\
\hline master - onderwijs & 3.200 & 4 & 0,7 \\
\hline Totaal (incl. bo, vmbo, mbo1, havo/vwo en overig) & 464.700 & 5 & 0,9 \\
\hline
\end{tabular}

Bron: ROA (AIS) 
De uitbreidingsvraag voor werkenden met een techniek en ICT-opleiding is ook relatief hoog. Opvallend is dat de uitbreidingsvraag voor techniek en ICT het kleinste is voor de master ( $0,8 \%$ per jaar). Binnen de master techniek en ICT wordt de grootste uitbreidingsvraag verwacht voor informatica ( $1,1 \%$ per jaar), chemische technologie ( $0,9 \%$ per jaar) en elektrotechniek (0,9\% per jaar). Binnen de bachelor techniek en ICT wordt de grootste uitbreidingsvraag verwacht voor informatica (1,0\% per jaar), chemische technologie (0,9\% per jaar) en elektrotechniek (0,9\% per jaar). Op mbo-niveau wordt de grootste groei in het aantal werkenden ook verwacht voor de ICT-gerelateerde opleidingen (ICT, media en vormgeving; ICT- en mediabeheer en ondersteuning; mediavormgeving). Op mbo 3-niveau is de uitbreidingsvraag voor bouw en infra ook hoog met 1,7\% per jaar.

Op mbo-niveau is de verwachte uitbreidingsvraag voor werkenden met een landbouw en natuur opleiding het laagst. De lage groei geldt voor alle onderliggende opleidingen. Op bachelor- en masterniveau is de uitbreidingsvraag voor landbouw, wiskunde en natuurkunde groter, $0,6 \%$ en $0,7 \%$ per jaar, respectievelijk. Op het niveau van de bachelor en master gaat het hier om landbouw- en natuuropleidingen die nauw aansluiten bij biochemische technologie en wis-schei-, en natuurkunde waar wel een groeiende vraag naar is op de arbeidsmarkt.

Op bachelor- en masterniveau is de uitbreidingsvraag voor opleidingen in de richting economie en recht beneden gemiddeld. Dit geldt voor alle onderliggende opleidingen. Ook de verwachte groei in het aantal werkenden met een opleiding journalistiek, gedrag en maatschappij, en kunst, taal en cultuur is beneden gemiddeld tot en met 2024. Alle onderliggende opleidingen voor deze richtingen laten eenzelfde beeld zien op bachelor- en masterniveau. De bacheloropleiding dienstverlening past in dit beeld met een verwachte uitbreidingsvraag van rond de 0,6\% per jaar tot en met 2024 .

Economie en administratie en dienstverlening op mbo-niveau laten eenzelfde beeld zien als deze opleidingen op bachelor- en masterniveau. De uitbreidingsvraag voor alle onderliggende opleidingen liggen stelselmatig lager dan de gemiddelde verwachte groei in de werkgelegenheid. Op het mbo laat de opleidingssubsector handel, ondernemerschap, transport en logistiek hetzelfde beeld zien met een lagere uitbreidingsvraag omdat ook voornamelijk de sector transport en logistiek minder gunstige groeiverwachtingen heeft.

\subsection{Vervangingsvraag}

Naast de uitbreidingsvraag wordt de vraag naar arbeidskrachten in de economie ook bepaald door het feit dat werkenden de arbeidsmarkt (tijdelijk) verlaten en vervangen moeten worden. Dit kan te wijten zijn aan migratie, arbeidsongeschiktheid, werkloosheid, (vervroegd) pensioen, of kinderzorg. Doorgaans laten vertrekkende werkenden voor hun beroep en opleidingsachtergrond een arbeidsplaats achter die opnieuw opgevuld moet worden. Twee belangrijke opmerkingen hierbij zijn dat (i) wanneer een beroep krimpt, moet er voor een uittredende werknemer geen vervanging gevonden 
worden en (ii) we zien dat over de jaren heen werknemers vaker worden vervangen door werknemers die hoger opgeleid zijn. Het prognosemodel houdt zowel rekening met de krimp als met de skills-upgrading.

De prognoses voor de vervangingsvraag worden enerzijds beïnvloed door het historische verloop van het aantal werkenden, en anderzijds door de verwachtingen in verband met de demografische ontwikkelingen en arbeidsparticipatie. Wat de demografische ontwikkelingen betreft, wordt een stijging van de gemiddelde leeftijd van de werkenden bijvoorbeeld weerspiegeld in een stijgende vervangingsvraag. Echter, wanneer de participatiegraad van ouderen stijgt, bijvoorbeeld door het versterken van de prikkel tot langer doorwerken, dan drukt dit weer op de vervangingsvraag.

Naast de (tijdelijke) uittreding uit de arbeidsmarkt, is het ook mogelijk dat werkenden vervangen dienen te worden doordat ze besluiten door te studeren in een hoger niveau of in een andere richting. De vervangingsvraag bij de lagere opleidingscategorieën (basisonderwijs, vmbo, havo/vwo) kan om die reden erg groot zijn omdat het hier vaak gaat om scholieren- of studentenbanen. De vraag naar deze lagere niveaus bepreken wij hier niet.

\section{Vervangingsvraag naar beroep}

De prognoses van de vervangingsvraag voor de periode 2019-2024 vinden we in Tabel 3.3. Voor de 12 beroepsklassen, toont de tweede kolom de vervangingsvraag in aantallen, de derde en vierde kolom in percentages ten opzichte van het aantal werkenden in het basisjaar 2018. Voor de volgende zes jaar, wordt verwacht dat er in totaal over alle beroepsklassen ruim 1,5 miljoen personen vervangen moeten worden.

In aantallen, is het vooral bij de bedrijfseconomische en administratieve beroepen (245.800), de transport en logistieke beroepen (231.000), en de technische beroepen (196.800), waar de meeste mensen moeten vervangen worden. Bij de agrarische beroepen (54.400), de creatieve en taalkundige beroepen (34.800), en de ICT-beroepen (26.000), moeten het minst mensen vervangen worden. Aangezien de absolute aantallen afhankelijk zijn van de grootte van een beroepsklasse in aantal werkenden, is het interessanter om ook te kijken naar de gemiddelde (jaarlijkse) percentages. Voor alle beroepsklassen samen, wordt er verwacht dat er gemiddeld 2,8\% per jaar vervangen moet worden. Wanneer we rekening houden met de grootte van de beroepsbevolking zien we dat het ditmaal in de transport en logistieke beroepen (5,3\%), de agrarische beroepen $(4,3 \%)$ en de dienstverlenende beroepen $(3,3 \%)$ is waar de meeste mensen vervangen moeten worden. Aan het ander uiteinde van de lijst bevinden zich de managers $(2,3 \%)$, de zorg en welzijn beroepen $(2,2 \%)$, en de qua leeftijdssamenstelling relatief jonge ICT-beroepen (1,1\%). 
TABEL 3.3 Vervangingsvraag naar beroepsklasse, in aantallen en als percentage van de werkgelegenheid in 2018, prognose 2019-2024

\begin{tabular}{|l|c|c|c|}
\hline & Aantal (6 jr.) & Totaal (6 jr.) \% & Gem. jaarlijks \% \\
\hline Pedagogische beroepen & 102.500 & 17 & 2,6 \\
\hline Creatieve en taalkundige beroepen & 34.800 & 16 & 2,4 \\
\hline Commerciële beroepen & 195.100 & 20 & 3,1 \\
\hline Bedrijfseconomische en administratieve beroepen & 245.800 & 15 & 2,4 \\
\hline Managers & 61.700 & 15 & 2,3 \\
\hline Openbaar bestuur, veiligheid en juridische beroepen & 56.200 & 19 & 2,9 \\
\hline Technische beroepen & 196.800 & 16 & 2,5 \\
\hline ICT-beroepen & 26.000 & 7 & 1,1 \\
\hline Agrarische beroepen & 54.400 & 29 & 4,3 \\
\hline Zorg en welzijn beroepen & 167.100 & 14 & 2,2 \\
\hline Dienstverlenende beroepen & 174.000 & 22 & 3,3 \\
\hline Transport en logistiek beroepen & 231.000 & 36 & 5,3 \\
\hline Totaal (incl. overig) & 1.574 .200 & 18 & 2,8 \\
\hline
\end{tabular}

Bron: ROA (AIS)

Vervolgens kijken we ook binnen beroepsklassen naar de voorspelde vervangingsvraag voor de beroepsgroepen per jaar. Voor de ICT-beroepen, vinden we dat er met name bij de databank- en netwerkspecialisten mensen moeten vervangen worden $(1,6 \%)$, en minder bij de software- en applicatieontwikkelaars (0,9\%). Voor de zorg en welzijn beroepen, liggen de jaarlijkse percentages tussen 3,3\% voor de medisch vakspecialisten, ten opzichte van 1,5\% voor de medisch praktijkassistenten.

Wat betreft de managers, is er een redelijke variatie binnen deze beroepsklasse doordat de verschillende soorten managers qua inhoudelijke en formele omschrijving van hun werkzaamheden erg kunnen verschillen. De grootste vervangingsvraag komt voor bij de managers onderwijs $(4,5 \%)$ en de managers zorginstellingen ( $4 \%)$. De kleinste, bij de managers logistiek (1,1\%).

Voor de creatieve en taalkundige beroepen is de spreiding zelfs groter. Hier is het grootste verschil in vervangingsvraag tussen bibliothecarissen en conservatoren $(6,7 \%)$ en grafisch vormgevers en productontwerpers $(1,1 \%)$. De eerstgenoemde groep is echter de kleinste (8.300) en de laatstgenoemde de grootste (60.200), vandaar dat het gemiddelde minder beïnvloed wordt.

In de groep van de bedrijfseconomische en administratieve beroepen zijn de verschillen groot wat betreft de aantallen, en minder groot wat betreft de jaarlijkse geschatte vervangingsvraag. Tot de grootste groepen behoren de administratief medewerkers (285.000) en transportplanners en logistiek medewerkers (182.000), tot de kleinste groepen behoren de secretaresses (53.400) en beleidsadviseurs (71.800). De grootste 
vervangingsvraag wordt geschat voor secretaresses $(3,6 \%)$, de kleinste voor transportplanners en logistiek medewerkers $(1,6 \%)$.

De beroepsklasse van de technische beroepen bevat de meeste onderliggende beroepsgroepen. De grootste vervangingsvraag per jaar hoort bij de bouwarbeiders afbouw en meubelmakers, kleermakers en stoffeerders (allebei 4,1\%). Twee beroepsgroepen zijn overduidelijk groter dan de andere; ingenieurs (exclusief elektrotechniek, 117.000) en technici bouwkunde en natuur (104.600). De kleinste groep is die van de elektrotechnisch ingenieurs (16.800).

De spreiding van de percentages van de vervangingsvraag over de pedagogische beroepen is niet groot. Onderwijskundigen en overige docenten hebben een geschatte vervangingsvraag van $3,3 \%$ gemiddeld per jaar, sportinstructeurs van $2,1 \%$ gemiddeld per jaar. Ook bij openbaar bestuur, veiligheid en juridische beroepen, zijn de onderlinge verschillen eerder klein. In deze beroepsgroep bedraagt de grootste vervangingsvraag $4 \%$ gemiddeld per jaar, de kleinste $2 \%$ gemiddeld per jaar.

Bij de commerciële beroepen wordt er verwacht dat de meeste mensen vervangen moeten worden bij de verkoopmedewerkers detailhandel $(4,1 \%)$. Dit is bovendien met voorsprong de grootste groep (339.200). Bij de adviseurs marketing, public relations en sales wordt de kleinste vervangingsvraag geschat $(1,1 \%)$. Bovendien is dit de tweede grootste groep binnen de beroepsklasse van de commerciële beroepen (162.600).

Bij de dienstverlenende beroepen ligt de geschatte vervangingsvraag tussen 3,9\% voor de conciërges en teamleiders schoonmaak, en 1,9\% voor de koks. De beroepsklasse van de agrarische beroepen is de meest gelijkaardige. Hier is het verschil tussen de grootste geschatte vervangingsvraag het kleinst, met name tussen land- en bosbouwers $(5,1 \%)$ en hulpkrachten landbouw (4,2\%). Ook de aantallen verschillen niet opmerkelijk veel: 73.800 voor hoveniers, tuinders en kwekers, en 28.100 voor hulpkrachten landbouw.

Ten slotte, de grootste geschatte vervangingsvraag per jaar, vinden we bij transport en logistiek beroepen. Meer bepaald, bij vuilnisophalers en dagbladenbezorgers (9,2\%). Dit hoeft echter niet te verbazen omdat het aantal werkenden scholieren hoog is waardoor we ook veel roulatie kunnen verwachten. Ook voor de buschauffeurs en trambestuurders $(6,1 \%)$ en laders, lossers en vakkenvullers $(5,7 \%)$, is de vervangingsvraag groot. Dekofficieren en piloten en bedieners van mobiele machines $(2,2 \%)$ hebben daarentegen de kleinste verwachte vervangingsvraag per jaar.

\section{Vervangingsvraag naar opleiding}

In navolging van tabel 3.3, toont tabel 3.4 de vervangingsvraag per opleidingscategorie. Net als bij de uitbreidingsvraag geldt dat door de nieuwe opleidingsclassificatie die ROA sinds dit jaar hanteert de cijfers moeilijk te vergelijken zijn met die in de vorige versie van dit rapport. Over alle opleidingen, bedraagt de vervangingsvraag in absolute aantallen ruim 1,6 miljoen personen. Dit komt neer op gemiddeld 2,9\% per jaar ten opzichte van het basisjaar 2018. 
TABEL 3.4 Vervangingsvraag naar opleidingscategorie, in aantallen en als percentage van de werkgelegenheid in 2018, prognose 2019-2024

\begin{tabular}{|c|c|c|c|}
\hline & Aantal (6 jr.) & Totaal (6 jr.) \% & Gem. Jaarlijks \% \\
\hline Mbo2 - economie en maatschappij & 13.600 & 10 & 1,5 \\
\hline Mbo2 - landbouw en natuur & 5.400 & 21 & 3,2 \\
\hline Mbo2 - techniek en ICT & 15.300 & 11 & 1,8 \\
\hline Mbo2 - zorg en dienstverlening & 39.600 & 23 & 3,5 \\
\hline Mbo3 - economie en administratie & 7.600 & 10 & 1,5 \\
\hline Mb03 - handel, ondernemerschap, transport en logistiek & 5.900 & 8 & 1,3 \\
\hline Mb03 - voedsel, natuur en leefomgeving & 7.300 & 12 & 1,9 \\
\hline Mbo3 - ICT, media en vormgeving & 4.900 & 18 & 2,8 \\
\hline Mb03 - techniek, bouw en procesindustrie & 29.000 & 15 & 2,3 \\
\hline Mbo3 - dienstverlening & 19.100 & 16 & 2,5 \\
\hline Mb03 - gezondheidszorg en welzijn & 23.200 & 13 & 2,1 \\
\hline Mbo4 - economie en administratie & 22.200 & 8 & 1,2 \\
\hline Mbo4 - handel, ondernemerschap, transport en logistiek & 19.700 & 13 & 2 \\
\hline Mbo4 - voedsel, natuur en leefomgeving & 22.100 & 26 & 3,9 \\
\hline Mbo4 - ICT, media en vormgeving & 11.900 & 14 & 2,2 \\
\hline Mb04 - techniek, bouw en procesindustrie & 79.300 & 26 & 3,9 \\
\hline Mb04-dienstverlening & 16.400 & 12 & 1,9 \\
\hline Mbo4 - gezondheidszorg en welzijn & 38.300 & 12 & 1,9 \\
\hline Bachelor - dienstverlening & 9.400 & 8 & 1,3 \\
\hline Bachelor - economie en recht & 58.900 & 11 & 1,8 \\
\hline Bachelor - journalistiek, gedrag en maatschappij & 13.800 & 13 & 2 \\
\hline Bachelor - kunst, taal en cultuur & 23.500 & 16 & 2,5 \\
\hline Bachelor - landbouw, wiskunde en natuurwetenschappen & 17.100 & 24 & 3,7 \\
\hline Bachelor - techniek en ICT & 87.900 & 27 & 4,1 \\
\hline Bachelor - gezondheidszorg en welzijn & 54.200 & 15 & 2,3 \\
\hline Bachelor - onderwijs & 62.600 & 23 & 3,5 \\
\hline Master - economie en recht & 58.500 & 13 & 2,1 \\
\hline Master - journalistiek, gedrag en maatschappij & 22.500 & 14 & 2,3 \\
\hline Master - kunst, taal en cultuur & 22.600 & 21 & 3,2 \\
\hline Master - landbouw, wiskunde en natuurwetenschappen & 21.100 & 20 & 3,1 \\
\hline Master - techniek en ICT & 42.500 & 27 & 4 \\
\hline Master - gezondheidszorg & 30.000 & 17 & 2,6 \\
\hline Master - onderwijs & 14.400 & 19 & 2,9 \\
\hline Totaal (incl. bo, vmbo, mbo1, havo/vwo en overig) & 1.629 .900 & 19 & 2,9 \\
\hline
\end{tabular}

Bron: ROA (AIS) 
Vervolgens analyseren we de verschillende opleidingscategorieën en zien we binnen het mbo 2 de grootste vervangingsvraag voor de richting zorg en dienstverlening (gemiddeld 3,1\% per jaar), en de kleinste voor de richting economie en maatschappij (1,5\%).

Wat betreft het mbo 3 hebben werkenden uit een afstudeerrichting ICT, media en vormgeving de hoogste vervangingsvraag (2,8\%). Personen uit een afstudeerrichting handel, ondernemerschap, transport en logistiek en economie en maatschappij moeten het minst vaak vervangen worden (1,3\% en 1,5\%, respectievelijk). De verschillen tussen de opleidingstypes in het mbo 3 zijn het grootst bij de richting dienstverlening, waar de opleiding horeca een gemiddelde jaarlijkse vervangingsvraag heeft van $1,7 \%$, terwijl veiligheid een gemiddelde jaarlijkse vervangingsvraag heeft van 4,0\%.

Bij het mbo 4 moeten er over het algemeen meer mensen vervangen worden; 3,9\% voor de richting techniek, bouw en procesindustrie en voor voedsel, natuur en leefomgeving. Wanneer we dieper ingaan op de onderliggende opleidingstypes binnen een opleidingscategorie vinden we veel variatie. Binnen de richting dienstverlening, steekt de opleiding facilitaire dienstverlening er bovenuit met een vervangingsvraag van $5,2 \%$. Bij de andere opleidingscategorieën zijn deze verschillen minder groot.

Over alle bachelor opleidingscategorieën heen, is de grootste vervangingsvraag te vinden bij de bachelor techniek en ICT $(4,1 \%)$. De laagste vervangingsvraag in de bachelor is voor de richting dienstverlening $(1,4 \%)$. Vooral bij de opleidingen bouwkunde, civiele techniek en architectuur (4,8\%); elektrotechniek $(4,7 \%)$; en werktuigbouwkunde $(4,5 \%)$, is er veel vraag naar mensen ter vervanging.

Ten slotte, ligt de gemiddelde jaarlijkse vervangingsvraag voor personen met een masterdiploma iets lager dan het gemiddelde $(2,7 \%)$. Net als in de bachelor, is de vervangingsvraag groot voor de techniek en ICT-opleidingen (4\%). Hierbinnen heeft de master werktuigbouwkunde de grootste vervangingsvraag $(5,1 \%)$, terwijl informatica de kleinste heeft (2,9\%). Gemiddeld, bedraagt de vervangingsvraag voor de masterrichting economie en recht $2 \%$, maar de opleiding marketing en public relations heeft van alle masteropleidingen de laagste vervangingsvraag $(0,7 \%)$.

\subsection{Baanopeningen}

De baanopeningen worden bepaald door de uitbreidingsvraag (waarbij enkel de positieve uitbreidingsvraag wordt meegerekend omdat de negatieve vraag niet tot vacatures leidt) en de vervangingsvraag. Aangezien er geprognostiseerd wordt dat er veel meer personen moeten vervangen worden dan dat er uitbreiding van de werkgelegenheid is, speelt de vervangingsvraag een belangrijkere rol in het bepalen van het totale aantal baanopeningen. 
Tabel 3.5 toont per beroepsklasse de prognoses voor het aantal baanopeningen in absolute aantallen alsook in percentages. In de laatste kolom, wordt het belang van de vervangingsvraag als aandeel van deze baanopeningen getoond. Zoals hierboven aangehaald, worden de baanopeningen voornamelijk bepaald door de vervangingsvraag, waardoor dit aandeel gemiddeld $76 \%$ is, en in een enkel geval (de agrarische beroepen) zelfs kan oplopen tot bijna $100 \%$.

Voor de periode van 2019 tot 2024, wordt het totaal aantal baanopeningen geschat op iets meer dan 2 miljoen. Deze worden berekend op het meest gedetailleerde niveau van de beroepsgroepen, waardoor de cijfers in tabel 3.5 kunnen afwijken van de optelsom van de uitbreidings- (tabel 3.1) en vervangingsvraag (tabel 3.3) van de beroepsklassen. Gemiddeld over alle beroepsklassen is dit $3,6 \%$ van de totale werkgelegenheid in het basisjaar 2018. Slechts $24 \%$ daarvan is het gevolg van de positieve uitbreidingsvraag. Ten opzichte van de vorige versie van dit rapport, zien we dat er meer baanopeningen zijn, wat wijst op een nog steeds gunstige economische situatie.

TABEL 3.5 Baanopeningen naar beroepsklasse, in aantallen en als percentage van de werkgelegenheid in 2018, prognose 2019-2024*

\begin{tabular}{|l|c|c|c|c|}
\hline & Aantal (6 jr.) & Totaal (6 jr.) \% & Gem. Jaarlijks \% & $\begin{array}{c}\text { Belang } \\
\text { vervangingsvraag } \\
\%\end{array}$ \\
\hline Pedagogische beroepen & & & & \\
\hline Creatieve en taalkundige beroepen & 117.100 & 19 & 2,9 & 87 \\
\hline Commerciële beroepen & 56.900 & 26 & 3,9 & 61 \\
\hline Bedrijfseconomische en administratieve beroepen & 220.100 & 22 & 3,4 & 89 \\
\hline Managers & 306.300 & 19 & 2,9 & 80 \\
\hline Openbaar bestuur, veiligheid en juridische beroepen & 96.500 & 23 & 3,4 & 64 \\
\hline Technische beroepen & 66.800 & 22 & 3,4 & 84 \\
\hline ICT beroepen & 274.100 & 22 & 3,4 & 72 \\
\hline Agrarische beroepen & 55.800 & 15 & 2,4 & 47 \\
\hline Zorg en welzijn beroepen & 55.500 & 30 & 4,4 & 98 \\
\hline Dienstverlenende beroepen & 338.900 & 28 & 4,2 & 49 \\
\hline Transport en logistiek beroepen & 205.300 & 25 & 3,8 & 85 \\
\hline Totaal (incl. overig) & 255.400 & 40 & 5,8 & 90 \\
\hline Aantallen zijn gebar & 2.077 .400 & 24 & 3,6 & 76 \\
\hline
\end{tabular}

* Aantallen zijn gebaseerd op berekeningen op het niveau van de onderliggende beroepsgroepen. Bron: ROA (AIS)

Net zoals de schattingen van de uitbreidings- en vervangingsvraag sterk kunnen verschillen tussen beroepsklassen, zo is het ook bij de baanopeningen. Bij de transport en logistieke beroepen $(5,8 \%)$, de agrarische beroepen $(4,4 \%)$ en de zorg en welzijn beroepen $(4,2 \%)$ verwachten we de meeste baanopeningen. Bij de eerste twee zien we ook het grootste aandeel van het belang van de vervangingsvraag (respectievelijk 
$90 \%$ en $98 \%$ ). Dit duidt op een grote uitstroom uit deze beroepsklassen die vervangen dient te worden, zelfs na eventuele correctie voor krimp van de onderliggende beroepsgroepen. Wat opvalt, is dat het aandeel van de vervangingsvraag bij de zorg en welzijn beroepen de op een na kleinste is (49\%). Binnen deze beroepsklasse is het vooral bij de verzorgenden waar er veel baanopeningen verwacht worden (5,4\% per jaar).

De creatieve en taalkundige beroepen hebben enkele van de hoogste cijfers voor het verwachte aantal baanopeningen; voornamelijk bibliothecarissen en conservatoren $(8,3 \%)$ en beeldend kunstenaars $(7,1 \%)$.

Bij de managers zien we opnieuw dat de prognoses sterk kunnen verschillen afhankelijk van het type manager. Voor de managers detail- en groothandel, commerciële en persoonlijke dienstverlening en onderwijs bijvoorbeeld, is deze steeds hoger dan 5\% per jaar. De managers logistiek hebben met 2,3\% de laagste verwachte omvang van baanopeningen.

Ook bij de beroepsklasse van openbaar bestuur, veiligheid en juridische beroepen, is er sprake van veel onderlinge variatie. Voor overheidsbestuurders worden er bijvoorbeeld veel baanopeningen verwacht $(5,8 \%)$, voor juristen een stuk minder $(2,4 \%)$. Overheidsambtenaren zijn het meest representatief ten opzichte van het gemiddelde voor deze beroepsklasse $(3,4 \%)$.

De klasse van de technische beroepen is groot en divers. Hier varieert het verwachte aantal baanopeningen tussen 5,6\% (bouwarbeiders afbouw) en 2,1\% per jaar (biologen en natuurwetenschappers, en elektrotechnisch ingenieurs).

De minste baanopeningen vinden wij voor de pedagogische beroepen $(2,9 \%)$, de bedrijfseconomische en administratieve beroepen (2,9\%) en de ICT-beroepen $(2,4 \%)$. Ook hier behoort bij de eerste twee het aandeel van de vervangingsvraag tot de hoogste (respectievelijk $87 \%$ en $80 \%$ ). De klasse van de ICT-beroepen, is ook een van de meest homogene wat betreft het verwachte aantal baanopeningen. Bovendien hebben deze beroepen het laagste aandeel van de vervangingsvraag van alle beroepsklassen (47\%). Met andere woorden, er is sprake van veel baancreatie.

Er lijkt dus geen duidelijke samenhang te zijn tussen het verwachte aantal baanopeningen en het belang van de vervangingsvraag: er zijn beroepen waarbij veel baanopeningen samengaan met een laag aandeel van de vervangingsvraag, en beroepen waarbij weinig baanopeningen samengaan met een hoog aandeel van de vervangingsvraag.

\section{Baanopeningen naar opleiding}

Voor de mbo 2 opleidingen (tabel 3.6), wordt het verwachte aantal baanopeningen als aandeel van de werkgelegenheid in het basisjaar geschat tussen 4,6\% per jaar voor de richting zorg en dienstverlening en $2,1 \%$ voor de richting economie en maatschappij. Wat betreft het aandeel vervangingsvraag, heeft techniek en ICT een percentage dat redelijk onder het gemiddelde ligt $(66,7 \%)$, terwijl de mbo 2 landbouw en natuur een van de hoogste percentages heeft (88\%). 
TABEL 3.6 Baanopeningen naar opleidingscategorie, in aantallen en als percentage van de werkgelegenheid in 2018, prognose 2019-2024

\begin{tabular}{|c|c|c|c|c|}
\hline & Aantal (6jr.) & Totaal (6 jr.) \% & $\begin{array}{c}\text { Gem. Jaarlijks } \\
\%\end{array}$ & $\begin{array}{l}\text { Belang } \\
\text { vervangings- } \\
\text { vraag } \%\end{array}$ \\
\hline Mbo2 - economie en maatschappij & 19.100 & 14 & 2,1 & 71,4 \\
\hline Mbo2 - landbouw en natuur & 6.100 & 24 & 3,6 & 88 \\
\hline Mbo2 - techniek en ICT & 22.900 & 17 & 2,6 & 66,7 \\
\hline Mb02 - zorg en dienstverlening & 52.700 & 31 & 4,6 & 75,2 \\
\hline Mbo3 - economie en administratie & 11.500 & 15 & 2,3 & 66,2 \\
\hline Mbo3 - handel, ondernemerschap, transport en logistiek & 9.200 & 12 & 2 & 64 \\
\hline Mbo3 - voedsel, natuur en leefomgeving & 8.900 & 15 & 2,3 & 81,3 \\
\hline Mbo3 - ICT, media en vormgeving & 6.600 & 24 & 3,7 & 74 \\
\hline Mbo3 - techniek, bouw en procesindustrie & 39.500 & 20 & 3,1 & 73,4 \\
\hline Mbo3 - dienstverlening & 24.800 & 21 & 3,2 & 77,1 \\
\hline Mbo3 - gezondheidszorg en welzijn & 45.200 & 26 & 3,9 & 51,3 \\
\hline Mbo4 - economie en administratie & 35.200 & 12 & 1,9 & 63 \\
\hline Mbo4 - handel, ondernemerschap, transport en logistiek & 25.300 & 17 & 2,6 & 77,7 \\
\hline Mbo4 - voedsel, natuur en leefomgeving & 24.300 & 28 & 4,2 & 91 \\
\hline Mbo4 - ICT, media en vormgeving & 16.800 & 20 & 3,1 & 70,7 \\
\hline Mbo4 - techniek, bouw en procesindustrie & 94.100 & 31 & 4,6 & 84,3 \\
\hline Mbo4 - dienstverlening & 22.500 & 17 & 2,6 & 72,8 \\
\hline Mbo4 - gezondheidszorg en welzijn & 70.200 & 22 & 3,3 & 54,5 \\
\hline Bachelor - dienstverlening & 14.100 & 12 & 1,9 & 66,8 \\
\hline Bachelor - economie en recht & 80.800 & 15 & 2,4 & 72,9 \\
\hline Bachelor - journalistiek, gedrag en maatschappij & 19.300 & 18 & 2,8 & 71,5 \\
\hline Bachelor - kunst, taal en cultuur & 31.900 & 22 & 3,4 & 73,8 \\
\hline Bachelor - landbouw, wiskunde en natuurwetenschappen & 19.700 & 28 & 4,2 & 86,4 \\
\hline Bachelor - techniek en ICT & 105.800 & 33 & 4,8 & 83,1 \\
\hline Bachelor - gezondheidszorg en welzijn & 91.700 & 25 & 3,8 & 59 \\
\hline Bachelor - onderwijs & 73.000 & 27 & 4,1 & 85,7 \\
\hline Master - economie en recht & 75.100 & 17 & 2,6 & 77,9 \\
\hline Master - journalistiek, gedrag en maatschappij & 29.700 & 19 & 2,9 & 75,9 \\
\hline Master - kunst, taal en cultuur & 27.900 & 26 & 3,9 & 81 \\
\hline Master - landbouw, wiskunde en natuurwetenschappen & 25.600 & 24 & 3,7 & 82,3 \\
\hline Master - techniek en ICT & 50.800 & 32 & 4,7 & 83,7 \\
\hline Master - gezondheidszorg & 48.900 & 27 & 4,1 & 61,3 \\
\hline Master - onderwijs & 17.600 & 23 & 3,5 & 81,8 \\
\hline Totaal (incl. overig, bo, vmbo, mbo 1 en havo/vwo) & 2.094 .600 & 24 & 3,6 & 77,8 \\
\hline
\end{tabular}

Bron: ROA (AIS) 
Bij het mbo 3 wordt het aantal baanopeningen over het algemeen lager voorspeld dan bij het mbo 2. De richting gezondheidszorg en welzijn heeft hier het hoogste percentage $(3,9 \%)$ en de richting handel, ondernemerschap, transport en logistiek het laagste $(2,0 \%)$. De opleidingen verschillen echter sterk in de mate waarin de baanopeningen het gevolg zijn van de vervangingsvraag. Terwijl de richting voedsel, natuur en leefomgeving een aandeel heeft van $81,3 \%$, is dit bij gezondheidszorg en welzijn slechts $51,3 \%$. Over de opleidingscategorieën heen, zien we dat de zorg opleidingen vaker gekenmerkt worden door een grote positieve uitbreidingsvraag.

Techniek, bouw en procesindustrie heeft binnen de mbo 4 het hoogste geschatte aantal baanopeningen per jaar $(4,6 \%)$. Deze worden bovendien voor het merendeel bepaald door de vervangingsvraag (84,3\%). Binnen het mbo 4 heeft alleen de richting voedsel, natuur en leefomgeving een hoger aandeel $(91,0 \%)$, wat ook het hoogste is over alle opleidingen in deze tabel. De richting economie en administratie heeft het laagste aantal geschatte baanopeningen per jaar $(1,9 \%)$.

Bij de bachelor heeft techniek en ICT met 4,8\% gemiddeld per jaar de meeste baanopeningen, en dienstverlening met 1,9\% gemiddeld per jaar de minste baanopeningen. Van alle bacheloropleidingen, is bij onderwijs het belang van de vervangingsvraag het grootst $(85,7 \%)$, bij gezondheidszorg en welzijn het laagst (59,0\%).

Ook bij de masteropleidingen heeft de techniek en ICT het hoogste aantal geraamde baanopeningen ( $4,7 \%)$. De laagste is de richting economie en recht $(2,6 \%)$. Wat betreft het aandeel van het belang van de vervangingsvraag, is deze ook in deze categorie gemiddeld hoogste $(76,6 \%)$, waarbij het gaat van $61,3 \%$ bij de richting gezondheidszorg tot $83,7 \%$ bij de richting techniek en ICT.

\subsection{Arbeidsmarktinstroom}

De perspectieven op de arbeidsmarkt zijn niet alleen afhankelijk van de vraag naar arbeid, maar ook van het nieuwe bijkomende aanbod. Om een uitspraak te kunnen doen over de perspectieven voor recent gediplomeerden op de arbeidsmarkt is het dus niet voldoende om alleen naar de vraagkant van de arbeidsmarkt te kijken. Veel vraag naar arbeid betekent nog niet dat de perspectieven op werk goed zijn, zeker als daar veel aanbod tegenover staat. De confrontatie tussen de vraag en het aanbod bepalen in welke richting de perspectieven zich ontwikkelen. Het arbeidsmarktaanbod bestaat voornamelijk uit de verwachte arbeidsmarktinstroom van gediplomeerden die het initiële onderwijs verlaten en instromen op de arbeidsmarkt. Op het moment dat een werkende op de arbeidsmarkt een diploma behaalt op een hoger opleidingsniveau en/of andere opleidingsrichting, is er ook sprake van instroom op de arbeidsmarkt. De ontwikkeling in de verwachte instroom wordt ook vergeleken met de instroom uit het recente verleden (2014-2018). Deze vergelijking wordt gemaakt om verschuivingen in de studiekeuze van scholieren en studenten inzichtelijk te maken, bijvoorbeeld een dalende of juist stijgende trend in het aantal gediplomeerden voor bepaalde oplei- 
dingen. De instroom laat ook vooral zien of er, in relatie tot het aantal werkenden met dezelfde opleidingsachtergrond op de arbeidsmarkt, een grote of een kleine instroom is. Naast de instroom op de arbeidsmarkt bestaat het aanbod op de arbeidsmarkt ook uit werklozen die korter dan één jaar op zoek zijn naar werk. Dit onderdeel van het aanbod wordt hier niet besproken. ${ }^{63}$

Tabel 3.7 geeft inzicht in de instroom van gediplomeerden op de arbeidsmarkt als onderdeel van het aanbod. In de komende 6 jaar stromen ruim 1,6 miljoen gediplomeerden de arbeidsmarkt in. Dat is 3\% van de totale werkgelegenheid in 2018 gemiddeld per jaar voor de komende prognoseperiode van 2019 tot en met 2024. In de vorige prognoses tot en met 2022 was de instroom nog iets hoger, waarmee de instroom dus verder afzwakt wat verklaard kan worden uit demografische ontwikkelingen in Nederland. De tendens van de laatste jaren zet zich ook voort wat betreft de ontwikkeling van de instroom per opleidingsniveau. Voor het mbo 2- en 3-niveau wordt een afname verwacht van de instroom voor de prognoseperiode ten opzichte van de instroom tussen 2014 en 2018. Het mbo 4, en de bachelor en master laten over het algemeen een tegengestelde ontwikkeling zien, namelijk een toename van de instroom. ${ }^{64}$ De instroomprognoses voor het opleidingsniveau tonen dat het gemiddelde opleidingsniveau van de werkzame beroepsbevolking de komende jaren verder zal stijgen.

Vanuit het mbo 2 neemt de instroom van alle werkenden op de arbeidsmarkt af tot en met 2024 ten opzichte van de instroom van mbo 2-gediplomeerden de afgelopen vijf jaar. In absolute en relatieve termen is de instroom vanuit het mbo 2 zorg en dienstverlening het grootste. Er stromen tussen 2019 en 2024 meer dan 45.000 werkenden in met een mbo 2 achtergrond in zorg en dienstverlening, wat $27 \%$ van de werkgelegenheid is op de arbeidsmarkt in 2018.

Alhoewel de instroom vanuit het mbo 3 afneemt ten opzichte van de afgelopen vijf jaar en de instroom vanuit het mbo 4 toeneemt ten opzichte van de afgelopen vijf jaar, laat de instroom van beide niveaus eenzelfde beeld zien wat richting betreft. De grootste instroom in absolute zin wordt verwacht voor opleidingen in gezondheidszorg en welzijn. Voor mbo ICT, media en vormgeving is de instroom in absolute aantallen niet zo hoog, maar ten opzichte van het aantal werkenden wordt een totale instroom van $30 \%$ over de komende 6 jaar verwacht op mbo 3 niveau, en zelfs een instroom van $44 \%$ over de komende 6 jaar op mbo 4 niveau. De instroom voor de overige opleidingssubsectoren is niet extreem laag of hoog. Voor de dienstverlenende opleidingen op mbo 3 en 4 niveau is de instroom rond de $4 \%$ per jaar. Voor de instroom van gediplomeerde technici op mbo 4 niveau geldt dat deze relatief laag wordt geschat, en naar schatting ook lager is dan de instroom van de afgelopen vijf jaar.

63 De aanname is dat langdurig werklozen geen concurrenten meer vormen voor gediplomeerden (M. de Graaf-Zijl, A. van der Horst \& D. van Vuuren (2015), Langdurige werkloosheid. Afwachten en hervormen. CPB Policy Brief 2015/11).

64 In de afgelopen twintig jaar is de beroepenstructuur in Nederland verschoven naar een gemiddelde hoger opleidingsniveau. Vanaf de jaren tachtig bedraagt de stijging van het opleidingsniveau ongeveer 2 opleidingsjaren. Zie: Bijlsma, I., Dijksman, S., Fouarge, D. \& Künn-Nelen, A. (2015). Winnaars en verliezers op de arbeidsmarkt 1996-2012. Tijdschrift voor Arbeidsvraagstukken, 31(2), 106-123. 
TABEL 3.7 Instroom op de arbeidsmarkt naar opleidingscategorie, in aantallen en als percentage van de werkgelegenheid in 2018, prognose 2019-2024

\begin{tabular}{|c|c|c|c|c|}
\hline & Aantal (6 jr.) & $\begin{array}{l}\text { Totaal } \\
\text { (6 jr.) \% }\end{array}$ & $\begin{array}{c}\text { Gem. } \\
\text { jaarlijks \% }\end{array}$ & $\begin{array}{c}\text { Feitelijk instroom } \\
\text { 2014-2018, gem. } \\
\text { jaarlijks \% }\end{array}$ \\
\hline Mbo2 - economie en maatschappij & 26.000 & 18 & 2,9 & 3,7 \\
\hline Mbo2 - landbouw en natuur & 6.200 & 24 & 3,7 & 5,8 \\
\hline Mbo2 - techniek en ICT & 23.600 & 17 & 2,7 & 3,8 \\
\hline Mbo2 - zorg en dienstverlening & 45.800 & 27 & 4 & 5,4 \\
\hline Mbo3 - economie en administratie & 16.100 & 20 & 3,1 & 3,6 \\
\hline Mbo3 - handel, ondernemerschap, transport en logistiek & 23.400 & 32 & 4,7 & 5,6 \\
\hline Mbo3 - voedsel, natuur en leefomgeving & 10.400 & 17 & 2,7 & 3,1 \\
\hline Mbo3 - ICT, media en vormgeving & 8.500 & 31 & 4,6 & 5,2 \\
\hline Mbo3 - techniek, bouw en procesindustrie & 40.700 & 21 & 3,2 & 3,0 \\
\hline Mbo3 - dienstverlening & 29.600 & 25 & 3,8 & 4,1 \\
\hline Mbo3 - gezondheidszorg en welzijn & 46.400 & 26 & 4 & 4,7 \\
\hline Mbo4 - economie en administratie & 60.900 & 21 & 3,2 & 3,0 \\
\hline Mbo4 - handel, ondernemerschap, transport en logistiek & 35.800 & 23 & 3,6 & 3,4 \\
\hline Mbo4 - voedsel, natuur en leefomgeving & 11.400 & 13 & 2,1 & 2,1 \\
\hline Mb04 - ICT, media en vormgeving & 37.200 & 44 & 6,3 & 6,2 \\
\hline Mb04 - techniek, bouw en procesindustrie & 38.300 & 13 & 2 & 2,2 \\
\hline Mbo4 - dienstverlening & 35.600 & 26 & 4 & 3,6 \\
\hline Mbo4 - gezondheidszorg en welzijn & 121.800 & 37 & 5,4 & 4,8 \\
\hline Bachelor - dienstverlening & 33.800 & 29 & 4,3 & 4,4 \\
\hline Bachelor - economie en recht & 120.500 & 23 & 3,4 & 3,4 \\
\hline Bachelor - journalistiek, gedrag en maatschappij & 39.500 & 37 & 5,4 & 5,6 \\
\hline Bachelor - kunst, taal en cultuur & 38.400 & 26 & 4 & 3,9 \\
\hline Bachelor - landbouw, wiskunde en natuurwetenschappen & 16.200 & 23 & 3,5 & 2,9 \\
\hline Bachelor - techniek en ICT & 48.900 & 15 & 2,4 & 2,1 \\
\hline Bachelor - gezondheidszorg en welzijn & 84.300 & 23 & 3,5 & 3,4 \\
\hline Bachelor - onderwijs & 47.000 & 17 & 2,7 & 2,9 \\
\hline Master - economie en recht & 92.800 & 21 & 3,2 & 3,1 \\
\hline Master - journalistiek, gedrag en maatschappij & 38.600 & 25 & 3,7 & 3,8 \\
\hline Master - kunst, taal en cultuur & 27.100 & 25 & 3,8 & 3,5 \\
\hline Master - landbouw, wiskunde en natuurwetenschappen & 31.400 & 30 & 4,5 & 3,7 \\
\hline Master - techniek en ICT & 32.600 & 20 & 3,1 & 2,5 \\
\hline Master - gezondheidszorg & 30.000 & 17 & 2,6 & 2,5 \\
\hline Master - onderwijs & 13.600 & 18 & 2,7 & 3,1 \\
\hline Totaal (incl. bo, vmbo, mbo1, havo/vwo en overig) & 1.620 .100 & 19 & 2,9 & 2,9 \\
\hline
\end{tabular}

Bron: ROA (AIS) 
Voor het onderwijs geldt dat er zowel op bachelor- als op masterniveau een afname van de instroom van gediplomeerden is ten opzichte van de afgelopen vijf jaar. Dit resulteert in een aanhoudende krapte voor leraren op de arbeidsmarkt (zie hoofdstuk 2). Een relatief hoge instroom is er voor de bachelor en master landbouw, wiskunde en natuurwetenschappen. Ook voor techniek en ICT wordt een stijgende instroom verwacht ten opzichte van de afgelopen jaren, vooral op masterniveau. Dit leidt er echter niet toe dat de absolute instroom of de instroom ten opzichte van het aantal werkende technici op de arbeidsmarkt heel erg hoog is. Dit is ook het geval voor andere opleidingen waarvoor er een hoge vraag is op de arbeidsmarkt, zoals gezondheidszorg en welzijn op bacheloren masterniveau. Verder valt het op dat de verwachte instroom in termen van het aantal werkenden voor de subsector bachelor journalistiek, gedrag en maatschappij ook hoog is, terwijl dit lager is dan de instroom van de afgelopen vijf jaar.

\subsection{Conclusie}

Over de prognoseperiode van 2019 tot 2024, worden er bijna 465.000 nieuwe banen verwacht. Ten opzichte van 2018 , is dit een groei van $5 \%$. De sterkste groei zien we bij de zorg en welzijn beroepen, namelijk $14 \%$ over de zes jaar, en bij de creatieve en taalkundige beroepen, bijna 10\% per jaar. In absolute cijfers gaat dit respectievelijk om 171.800 en 22.100 nieuwe banen. Daarmee is de zorg en welzijn ook de beroepsklasse waar in aantallen de meeste nieuwe banen worden gecreëerd, gevolgd door de technische beroepen waar er in totaal 69.700 nieuwe banen bij komen. De enige beroepsklasse waar we een negatieve groei zien, zijn de agrarische beroepen. Een negatieve groei van $-0,3 \%$ betekent in totaal 500 minder banen voor de agrarische beroepen over de komende zes jaar. Deze cijfers worden weerspiegeld in de uitbreidingsvraag naar werknemers met een bepaalde opleidingsachtergrond. Ook hier is de uitbreidingsvraag relatief het grootst naar werknemers met een mbo 3-diploma gezondheidszorg en welzijn, namelijk 13\% over zes jaar. De bacheloropleidingen in de gezondheidszorg en welzijn, en de masteropleidingen in de gezondheidszorg completeren de top drie met een groei van ongeveer $10 \%$. In absolute aantallen tellen deze drie subsectoren gezamenlijk voor $17 \%$ van het totale aantal nieuwe banen.

Tussen 2019 en 2024, wordt een vervangingsvraag geschat die meer dan drie keer zo groot is als de uitbreidingsvraag. In totaal, wordt er verwacht dat er bijna 1,6 miljoen werkenden vervangen moeten worden, dat is $18 \%$ van het totaal aantal werkenden. Bij de bedrijfseconomische en administratieve beroepen, moeten er naar verwachting de meeste mensen vervangen worden, namelijk 245.800 . Ook bij de transport en logistieke beroepen, de technische beroepen en de commerciële beroepen, lopen deze cijfers op tot rond de 200.000 . Wanneer we naar de relatieve groeicijfers kijken, vinden we met $36 \%$ de sterkste groei bij de transport en logistieke beroepen, gevolgd door $29 \%$ bij de agrarische beroepen. Er wordt verwacht dat bij de ICT-beroepen het minst aantal mensen vervangen zal moeten worden. Dit is tevens, samen met de zorg en welzijn beroepen, de enige beroepsklasse waarbij de uitbreidingsvraag groter is dan de vervangingsvraag. Wat betreft de vraag naar gediplomeerden vanuit een bepaalde opleiding 
als gevolg van vervanging, is deze het grootst voor de technische opleidingen. De mbo niveau 4 opleidingen in techniek, bouw en procesindustrie, de bachelor opleidingen in techniek en ICT en de master opleidingen techniek en ICT, hebben met respectievelijk $26,1 \%, 27 \%$, en $26,5 \%$ de grootste vervangingsvraag. In totaal gaat het om 209.700 werknemers die in de komende zes jaar vervangen moeten worden.

Voor de periode van 2019 tot 2024, worden er ruim 2 miljoen baanopeningen verwacht (de optelsom van uitbreidingsvraag en vervangingsvraag). Ten opzichte van 2018, is dit een groei van $24 \%$ over alle beroepsklassen heen. We zagen al dat de vervangingsvraag een veelvoud is van de uitbreidingsvraag. Het is dan ook niet verwonderlijk dat de vervangingsvraag voor ongeveer drie kwart de baanopeningen bepaalt. Rekening houdend met deze twee componenten, wordt de grootste groei van het aantal baanopeningen verwacht voor de transport en logistieke beroepen, namelijk 40\%, en voor de agrarische beroepen, bijna 30\%. In beide gevallen worden deze bijna volledig bepaald door de vervangingsvraag. In absolute aantallen, zijn het de zorg en welzijn beroepen, en de bedrijfseconomische en administratieve beroepen waar met respectievelijk 338.900 en 306.300 de meeste baanopeningen worden verwacht. Bij de zorg en welzijn beroepen, komt dit echter voor het grootste deel door een toename van de werkgelegenheid of de uitbreidingsvraag. Ook bij de baanopeningen naar opleidingscategorie zien we hetzelfde beeld als hierboven beschreven, de grootste groei vinden we bij de vraag naar de technische opleidingen van het mbo 4, bachelor en master, gevolgd door de zorg opleidingen. De groeipercentages liggen hier rond de 30\%. Ook in absolute aantallen, stijgen deze ver uit boven de andere opleidingen.

Het aanbod op de arbeidsmarkt door de instroom van gediplomeerden laat zien dat er de komende zes jaar ruim 1,6 miljoen potentiele nieuwe werkenden komen. Vanuit het mbo 2 en 3 wordt een afname van de instroom verwacht ten opzicht van de voorgaande vijf jaar. Voor het mbo 3 en de bachelor en master wordt over het algemeen een toename van de instroom op de arbeidsmarkt verwacht. Opvallend is dat zowel de verwachte instroom van bachelor onderwijs en master onderwijs lager is dan de afgelopen 5 jaar. 


\section{BIJLAGE A: CENTRALE BEGRIPPEN BIJ DE ARBEIDSMARKTPROGNOSES}

\section{Arbeidsmarktinstroom van gediplomeerden}

Het aanbod van nieuwe arbeidskrachten op de arbeidsmarkt, zoals deze is bepaald door de verwachte uitstroom van schoolverlaters uit het initiële dagonderwijs, de schoolverlaters van het deeltijdonderwijs, het niet-reguliere voltijdonderwijs en de beroepsgerichte volwasseneneducatie. Daarbij wordt de benaming 'schoolverlater' meestal ook gehanteerd voor de afgestudeerden van het hoger onderwijs.

\section{Publicaties:}

A. de Grip en A. Jacobs (1999), De doorstroom van het initieel naar het niet-initieel onderwijs, ROA-W-1999/3, Universiteit Maastricht.

F. Cörvers en B. Golsteyn (2003), De invloed van voortijdige schooluitval op de instroomprognoses van schoolverlaters op de arbeidsmarkt, ROA-W-2003/1, Universiteit Maastricht.

\section{Arbeidsvolume}

Het totaal aantal arbeidsjaren, waarbij is uitgegaan van een werkweek van 40 uur.

\section{Baanopeningen}

De totale vraag naar nieuwkomers op de arbeidsmarkt, zoals deze is bepaald door de werkgelegenheidsgroei (positieve uitbreidingsvraag) en de vervangingsvraag. Bij het vaststellen van het aantal baanopeningen wordt ermee rekening gehouden dat het aannemen van gediplomeerden door bedrijven en instellingen ('de vraag naar gediplomeerden') op nagenoeg hetzelfde niveau blijft ondanks een eventuele werkgelegenheidskrimp vanwege de extra uitstroom van ouderen. Het blijkt dat werkgevers voor het realiseren van een teruglopende vraag naar arbeid aan de 'exit'- optie de voorkeur geven boven de 'no entry'-optie van bijvoorbeeld gediplomeerden. Een werkgelegenheidskrimp voor een opleidingstype of beroepsgroep gaat derhalve nauwelijks ten koste van de vervangingsvraag of het aantal baanopeningen in een opleidingstype of beroepsgroep. 


\section{Publicaties:}

A. de Grip, P. Meijboom and E. Willems (1994), 'Vacancies, Employment Growth and the Demand for Newcomers on the Labour Market', in: J. Muijsken (ed.), Measurement and Analysis of Job Vacancies, Avebury, Aldershot/Brookfield (USA), pp. 101-125.

E. Willems, L. Borghans and A. de Grip (1997), Exit or no entry? Replacement demand and shrinking employment, ROA, Paper for the EALE conference, Aarhus, Denmark.

\section{Bedrijfssector}

De in dit rapport gepresenteerde informatie is veelal verbijzonderd naar 21 bedrijfssectoren (zie Bijlage B). Deze indeling is gebaseerd op de Standaard Bedrijfsindeling 2008 (SBI '08) van het CBS.

\section{Beroepsgroep}

In dit rapport wordt uitgegaan van 113 beroepsgroepen over de volle breedte van de arbeidsmarkt. Deze zijn geclusterd tot 12 beroepsklassen (plus 1 groep en de klasse voor 'overig', zie Bijlage B). De indeling is afgeleid van de ISCO- beroepen en tot stand gekomen in samenwerking met CBS.

\section{Publicatie:}

ROA (2015), Beroepenindeling ROA-CBS 2014 (BRC 2014), Maastricht: ROA-TR-2015/5.

\section{Beroepsbevolking}

De beroepsbevolking omvat de werkenden en de werkzoekenden zonder baan. ledereen met een leeftijd tussen de 15 en 74 jaar, die minstens 1 uur per week betaalde arbeid verricht (werkzame beroepsbevolking) of recent naar betaald werk heeft gezocht en daarvoor direct beschikbaar is (werkloze beroepsbevolking). De definitie van de beroepsbevolking is afkomstig van het CBS (www.cbs.nl).

\section{Publicatie:}

Ineke Bijlsma, Sander Dijksman, Didier Fouarge, Annemarie Künn-Nelen, Davey Poulissen (2015). Veranderingen in de omvang en samenstelling van de beroepsbevolking als gevolg van de overstap op de ILO-definitie van de beroepsbevolking. Maastricht: ROA-TR-2015/6.

\section{Conjunctuurgevoeligheid}

De conjunctuurgevoeligheid van de werkgelegenheid heeft betrekking op de mate waarin de werkgelegenheid in een beroepsgroep, of voor mensen met een bepaalde opleidingsachtergrond, gevoelig is voor veranderingen van de economische situatie. Deze indicator geeft daarmee de mate van werkzekerheid aan. De conjunctuurgevoeligheid wordt bepaald door de sectorale werkgelegenheidsfluctuaties in het verleden te relateren aan de mate waarin een beroepsgroep of opleidingstype momenteel in de 
verschillende bedrijfssectoren is vertegenwoordigd. Hierbij wordt rekening gehouden met het feit dat niet ieder beroep even sterk mee fluctueert met de werkgelegenheidsschommelingen van de bedrijfssector.

\section{Flexibele arbeidsrelatie}

Van een flexibele arbeidsrelatie is sprake bij uitzendkrachten, oproepkrachten, invalskrachten, contracten zonder een vast aantal arbeidsuren en indien geen vast dienstverband is overeengekomen. Een arbeidscontract wordt als niet-vast beschouwd als de contractuele termijn van beperkte duur is.

\section{Publicaties:}

D. Fouarge, A. De Grip, W. Smits, R. De Vries (2012). Flexible contracts and human capital investments. De Economist, 160(2): 177-195.

F. Cörvers, J. van Thor (2010), Flexwerk in Nederland, ROA-TR-2010/2, Universiteit Maastricht.

\section{Knelpunten in de personeelsvoorziening naar beroep}

Om inzicht te verschaffen hoe de aansluitingsproblematiek tussen onderwijs en arbeidsmarkt zijn weerslag heeft op de wervingsproblematiek in de verschillende beroepsgroepen, wordt gebruik gemaakt van de Indicator Toekomstige Knelpunten in de Personeelsvoorziening naar Beroep (ITKB). De ITKB geeft aan in welke mate het voor werkgevers mogelijk is om de gewenste personeelssamenstelling naar opleidingsachtergrond binnen beroepsgroepen te realiseren, bij de voorspelde vraag- aanbodverhoudingen voor de verschillende opleidingstypen. De ITKB heeft een waarde tussen o en 1. Naarmate de waarde van de indicator lager is, zijn de knelpunten in de personeelsvoorziening voor de betreffende beroepsgroep groter. Werkgevers zullen dan relatief veel moeite hebben nieuw personeel met de door hen gewenste opleidingsachtergrond te vinden. Wanneer de ITKB daarentegen bijna gelijk is aan 1, zullen werkgevers weinig moeite hebben de gewenste personeelssamenstelling binnen het beroep te realiseren. Voor die opleidingen die aandacht schenken aan de in dat beroep relevante kennis en vaardigheden, worden dan geringe knelpunten verwacht.

\section{Knelpunten in de personeelsvoorziening naar opleiding}

Als de vraag naar werkenden met een bepaalde opleidingsachtergrond groter is dan het aanbod kunnen knelpunten in de personeelsvoorziening voor werkgevers verwacht worden. Vergelijkbaar met de Indicator Toekomstige Arbeidsmarktperspectieven (ITA) geeft de Indicator van de Toekomstige Knelpunten in de Personeelsvoorziening (ITKP) deze vraag-aanbod-spanning per opleidingstype aan. Verschil met de ITA is dat bij de ITKP de uitstroom van werkenden als gevolg van een krimpende werkgelegenheid is meegerekend in de vraag, omdat verwacht mag worden dat bij knelpunten in de personeelsvoorziening deze (gedwongen) uitstroom kan worden afgeremd of dat werknemers 
elders werk zouden kunnen vinden. Naarmate de waarde van de indicator lager is, zijn de verwachte knelpunten groter.

\section{Onderbenutting}

Een indicatie van de mate waarin arbeidskrachten werkzaam zijn op een functieniveau dat lager is dan hun opleidingsniveau. De mate van onderbenutting is vastgesteld door de gediplomeerden aan te laten geven in hoeverre de werkgever het verworven opleidingsniveau vereist voor de uitgeoefende functie.

\section{Publicatie:}

J. Coenen, F. Cörvers, D. Fouarge, C. Meng, A. Nelen (2009), 'Onderbenutting van mbo'ers nuttig op de arbeidsmarkt?', TPEdigitaal, Vol. 3, pp. 103-123.

\section{Opleidingstype}

Alle voorkomende opleidingen zijn samengevoegd tot een aantal clusters. In dit rapport worden 108 opleidingstypen onderscheiden (inclusief opleidingstype 'overig'). Deze zijn geclusterd tot 47 opleidingssubsectoren, inclusief de categorie 'overig' (zie Bijlage B).

\section{Publicatie:}

Bakens, J., S. Dijksman, en D. Fouarge (2019). Opleidingsclassificatie naar niveau en richting 2019: achtergronddocumentatie, ROA Technical Reports no.01, Maastricht: Research Centre for Education and the Labour Market.

\section{Potentiële beroepsbevolking}

De potentiële beroepsbevolking omvat alle personen tussen de 15 en de 74 jaar, voor zover hun belangrijkste activiteit niet studie betreft. Scholieren en studenten worden dus niet tot de potentiële beroepsbevolking gerekend. De potentiële beroepsbevolking omvat daarmee naast de beroepsbevolking ook de niet-participerenden.

\section{Startkwalificatie}

Het Nederlandse onderwijsbeleid is erop gericht om jongeren minimaal een startkwalificatie te laten behalen, dat wil zeggen een opleiding overeenkomend met niveau 2 (basisberoepsbeoefenaar) van de kwalificatiestructuur voor de beroepsopleidende leerweg (bol) en de beroepsbegeleidende leerweg (bbl) van het secundair beroepsonderwijs. Ook de tweede fase vo (havo of vwo) leidt tot een startkwalificatie. Globaal betekent dit dat na het verlaten van het vmbo nog een beroepsopleiding moet worden gevolgd via de bol of de bbl met een minimale opleidingsduur van 2 jaar (voorheen tweejarig kmbo respectievelijk primair leerlingwezen). De startkwalificatie - of het niveau van basisberoepsbeoefenaar - wordt gezien als het niveau dat minimaal noodzakelijk is om op een goede manier te kunnen functioneren op de snel veranderende arbeidsmarkt. De grens 
tussen wel of geen startkwalificatie is vanuit arbeidsmarktoptiek gelegen rond niveau 1 of 2 . De verschillende niveaus binnen het mbo kunnen in dit rapport meestal niet als zodanig worden onderscheiden. Om deze reden wordt een opleiding op mbo-niveau 2, 3 of 4 doorgaans beschouwd als een startkwalificatie voor de arbeidsmarkt, tenzij anders is aangegeven. Alle opleidingen van mbo-niveau 1 (assistentberoepsbeoefenaar) zijn in dit rapport ingedeeld op vmbo-niveau.

\section{Publicaties:}

R. van der Velden, R. de Vries, M. Wolbers en P. van Eijs (2002), De waarde van een startkwalificatie, ROA-R-2002/14, Universiteit Maastricht.

W.A. Houtkoop, R.K.W. van der Velden en T.F. Brandsma (2004), De waarde van de startkwalificatie, Max Goote bve, mei.

\section{Substitutie-effect (passief en actief)}

Als gevolg van discrepanties tussen vraag en aanbod op de arbeidsmarkt treden er verschuivingen op in de werkgelegenheidsstructuur. Gediplomeerden in een aanbodoverschotsituatie kunnen anders opgeleiden gaan verdringen, terwijl werkgevers die te kampen hebben met een tekortschietend arbeidsaanbod, personen met een andere opleidingsachtergrond kunnen gaan werven. De vraag die hierdoor verloren gaat of ontstaat wordt aangeduid als het passieve substitutie-effect. Als het passieve substitutie-effect positief is, gaat het om extra baanopeningen als gevolg van tekorten bij andere opleidingen. Een negatief substitutie-effect duidt daarentegen op een verlies aan baanopeningen, omdat men verdrongen wordt door andere opleidingen. Het actieve substitutie-effect geeft - als het positief is - aan in hoeverre werkenden met een opleidingsachtergrond waarvoor er een aanbodoverschot is door een verhevigde concurrentie alsnog werk zullen vinden door arbeidskrachten met een andere opleidingsachtergrond te verdringen. Een negatieve actieve substitutie geeft daarentegen aan welke werkgelegenheid niet meer vervuld zal worden als gevolg van de verwachte aanbodtekorten.

\section{Publicaties:}

L. Borghans and H. Heijke (1994), 'Forecasting the educational structure of occupations: A manpower requirement approach with substitution', Labour, Vol. 10, pp. 151-192. A. de Grip, L. Borghans and W. Smits (1998), 'Future developments in the job level and domain of highly-skilled workers', in: H. Heijke, L. Borghans (eds), Towards a transparent Labour Market for Educational Decisions, Ashgate, Aldershot/Brookfield USA/Singapore/Sydney, pp. 21-56.

F. Cörvers and H. Heijke (2004), Forecasting the labour market by occupation and education: Some key issues, ROA-W-2004/4, Universiteit Maastricht. 


\section{Substitutiemogelijkheden bij de personeelswerving}

De mate waarin werkgevers voor een bepaald beroep arbeidskrachten kunnen aantrekken met een uiteenlopende opleidingsachtergrond, zodat ze niet afhankelijk zijn van het arbeidsaanbod van een bepaald opleidingstype. De substitutiemogelijkheden worden bepaald met behulp van een spreidingsindex.

\section{Toekomstig arbeidsmarktperspectief naar opleiding}

Het toekomstig arbeidsmarktperspectief geeft de verhouding tussen aanbod en vraag in de prognoseperiode voor een opleidingstype weer. De vraag- en aanbodprognoses zijn gebaseerd op de actuele arbeidsmarktpositie van een opleiding. Als het arbeidsmarktperspectief van een opleiding slecht is, betekent dit dat er de komende jaren veel meer aanbod van nieuwkomers is dan baanopeningen. Hierdoor zal de arbeidsmarktpositie gaan verslechteren. Deze verslechtering kan een hogere werkloosheid betekenen, maar door aanpassingsprocessen op de arbeidsmarkt kan de verslechtering van de arbeidsmarktsituatie ook leiden tot het moeten aanvaarden van banen op een lager niveau, een lagere beloning en meer tijdelijke contracten. Omgekeerd zal een goed perspectief leiden tot een grotere kans op werk, maar ook tot een verbeterde positie op andere punten. Het toekomstig arbeidsmarktperspectief per opleidingstype wordt bepaald door middel van de Indicator Toekomstig Arbeidsmarktperspectief (ITA), die is gedefinieerd als de verhouding tussen enerzijds de verwachte arbeidsmarktinstroom van gediplomeerden en het aantal kortdurig werklozen en anderzijds de verwachte baanopeningen en de passieve substitutievraag. Naarmate de waarde van de indicator hoger is wordt het perspectief slechter.

\section{Publicaties:}

M.H. Wieling, A. de Grip en E.J.T.A. Willems (1990), Een systematische kwalitatieve typering van arbeidsmarktinformatie, ROA-W-1990/8, Universiteit Maastricht.

F. Cörvers, A. de Grip and H. Heijke (2002), 'Beyond manpower planning: a labour market model for the Netherlands and its forecasts to 2006', in M. Neugart and K. Schömann (eds), Forecasting Labour Markets in OECD Countries, Cheltenham (UK) and Northampton MA (USA), Edward Elgar, pp. 185-223.

A. Dupuy (2009), An evaluation of the indicator of the labour market gap, ROA-TR2009/1, Universiteit Maastricht.

\section{Uitbreidingsvraag}

De vraag naar nieuwe arbeidskrachten die ontstaat door groei van de werkgelegenheid. Als er sprake is van een werkgelegenheidsdaling, is de uitbreidingsvraag negatief.

\section{Publicaties:}

F. Cörvers and A. Dupuy (2006), Explaining the Occupational Structure of Dutch Sectors of Industry, 1988-2003, ROA-W-2006/7E, Universiteit Maastricht. 
F. Cörvers en A. Dupuy (2007), Beroepenmodel voor het onderwijs en de zorg: werkgelegenheid en prognoses, ROA-W-2007/3, Universiteit Maastricht.

F. Cörvers and A. Dupuy (2010), 'Estimating employment dynamics across occupations and sectors of industry', Journal of Macroeconomics, Vol. 32, pp. 17-27.

D. Bertrand-Cloodt (2010), Evaluatie uitbreidingsvraag en indicator toekomstige arbeidsmarktsituatie (ITA) tot 2008, ROA-TR-2010/6, Universiteit Maastricht.

\section{Uitwijkmogelijkheden}

De mate waarin arbeidskrachten met een bepaalde opleidingsachtergrond of met een bepaald beroep terecht kunnen komen in andere beroepsgroepen op een aansluitend of hoger functieniveau, respectievelijk in andere bedrijfssectoren. Deze maatstaf geeft daarmee aan in hoeverre arbeidskrachten afhankelijk zijn van de arbeidsmarktsituatie in een bepaald beroep of een bepaalde bedrijfssector. De uitwijkmogelijkheden worden bepaald met behulp van een spreidingsindex. Deze index geeft een indicatie van het aantal beroepsgroepen of bedrijfssectoren waarnaar men kan uitwijken.

\section{Publicatie:}

L. Borghans and H. Heijke (1998),'Flexibility and the Structure of the Dutch Labour Market', in: H. Heijke, L. Borghans (eds), Towards a transparent Labour Market for Educational Decisions, Ashgate, Aldershot/Brookfield USA/Singapore/Sydney, pp. 119-150.

\section{Upgrading}

Door een toenemende complexiteit van de te verrichten werkzaamheden kunnen er voor een bepaald beroep door werkgevers hogere opleidingseisen worden gesteld. In dat geval spreekt men van upgrading van de kwalificatie-eisen. Overigens kan ook een verschuiving van de werkgelegenheid van lagere naar hogere beroepen als een upgradingsproces worden getypeerd.

\section{Publicaties:}

L. Borghans and A. de Grip (2000), Skills and Low Pay: 'Upgrading or Overeducation?',in: M. Gregory, W. Salverda and S. Bazen (eds), Labour Market Inequalities, Problems and Policies of Low-Wage Employment in International Perspective, Oxford University Press, Oxford, pp. 198-223.

A. Dupuy (2006), Measuring Skill-upgrading in the Dutch Labor Market, ROA-W-2006/3E, Universiteit Maastricht.

A. Dupuy (2007), 'Will the skill-premium in the Netherlands rise in the next decades?', Applied Economics, Vol. 39, pp. 2723-2731.

\section{Verdringing}

Indien de arbeidskrachten met een bepaalde opleidingsachtergrond vanwege een aanbodoverschot bij een ander opleidingstype, te kampen hebben met een dalend 
werkgelegenheidsaandeel in de beroepen waarin zij werkzaam zijn, is er sprake van verdringing. Meer technisch wordt dit ook wel aangeduid als een negatief passief substitutie-effect. Bij het opleidingstype dat de anders opgeleiden verdringt is er sprake van een positief actief substitutie-effect.

\section{Publicaties:}

A. de Grip, L. Borghans and W. Smits (1998), 'Future developments in the job level and domain of highly-skilled workers', in: H. Heijke, L. Borghans (eds), Towards a transparent Labour Market for Educational Decisions, Ashgate, Aldershot/Brookfield USA/Singapore/ Sydney, pp. 21-56.

F. Cörvers and H. Heijke (2004), Forecasting the labour market by occupation and education: Some key issues, ROA-W-2004/4, Universiteit Maastricht.

\section{Vervangingsvraag}

De vraag naar nieuwe arbeidskrachten die ontstaat doordat de arbeidsplaatsen van werkenden die met pensioen gaan, arbeidsongeschikt worden of zich (tijdelijk) terugtrekken van de arbeidsmarkt opnieuw moeten worden opgevuld. De vervangingsvraag per beroepsgroep kan bovendien ontstaan door beroepsmobiliteit. De vervangingsvraag naar opleidingstype kan bovendien ontstaan wanneer arbeidskrachten door middel van niveauverhogende of richtingveranderende scholing aanvullende kwalificaties weten te verwerven. Vertrek van werkenden dat niet leidt tot vraag naar nieuwkomers uit hetzelfde opleidingstype of dezelfde beroepsgroep wordt niet meegerekend als vervangingsvraag.

\section{Publicaties:}

E.J.T.A. Willems and A. de Grip (1993), 'Forecasting Replacement Demand by Occupation and Education', International Journal of Forecasting, Vol. 9, pp. 173-185. E. Willems (1999), Modelling Replacement Demand: A Random Coefficient Approach, ROA-RM-1999/2E, Universiteit Maastricht.

F. Cörvers, B. Kriechel en R. Montizaan (2006), Scenario-analyse van de vervangingsvraag tot 2010, ROA-W-2006/1, Universiteit Maastricht.

R. Montizaan (2009), Evaluatie vervangingsvraagprognoses naar opleiding en beroep, ROA-TR-2009/1, Universiteit Maastricht.

\section{Werkloosheid}

Werklozen zijn personen tussen de 15 en de 74 jaar die geen betaald werk hebben, maar wel recent naar werk hebben gezocht en daarvoor direct beschikbaar zijn (www.cbs. $\mathrm{nl}$ ). Het werkloosheidspercentage wordt bepaald door het aantal werklozen te relateren aan de beroepsbevolking. Kortdurig werklozen worden gedefinieerd als personen die minder dan een jaar werkloos zijn. 


\title{
BIJLAGE B: CLASSIFICATIES NAAR BEDRIJFSSECTOR, BEROEP EN OPLEIDING
}

\author{
Bedrijfssectoren \\ Landbouw, bosbouw en visserij \\ Voedings- en genotmiddelenindustrie \\ Chemische industrie \\ Metaalindustrie \\ Overige industrie \\ Energie \\ Bouwnijverheid \\ Detailhandel \\ Groothandel \\ Vervoer en opslag \\ Horeca \\ Informatie en communicatie \\ Financiële dienstverlening en onroerend goed \\ Specialistische zakelijke dienstverlening \\ Verhuur en overige zakelijke dienstverlening \\ Openbaar bestuur en overheidsdiensten \\ Onderwijs \\ Zorg \\ Welzijn \\ Cultuur sport en recreatie \\ Overige dienstverlening, huishoudens en extraterritoriale organisaties
}

Beroepsklassen, beroepssegment en onderliggende beroepsgroepen ${ }^{65}$

Beroepsklasse

Beroepssegment

Beroepsgroep

Pedagogische beroepen

Docenten

Docenten hoger onderwijs en hoogleraren

Docenten beroepsgerichte vakken secundair onderwijs

Docenten algemene vakken secundair onderwijs

Leerkrachten basisonderwijs

Onderwijskundigen en overige docenten

Sportinstructeurs

Sportinstructeurs

Leidsters kinderopvang en onderwijsassistenten

Leidsters kinderopvang en onderwijsassistenten

Creatieve en taalkundige beroepen

Auteurs en kunstenaars

65 Zie: ROA/CBS (2015), Beroepenindeling ROA-CBS 2014 (BRC 2014), Maastricht: ROA-TR-2015/5. 
Bibliothecarissen en conservatoren

Auteurs en taalkundigen

Journalisten

Beeldend kunstenaars

Uitvoerend kunstenaars

Vakspecialisten op artistiek en cultureel gebied

Grafisch vormgevers en productontwerpers

Fotografen en interieurontwerpers

Commerciële beroepen

Adviseurs marketing, public relations en sales

Adviseurs marketing, public relations en sales

Vertegenwoordigers en inkopers

Vertegenwoordigers en inkopers

Verkopers

Winkeliers en teamleiders detailhandel

Verkoopmedewerkers detailhandel

Kassamedewerkers

Callcentermedewerkers outbound en overige verkopers

Bedrijfseconomische en administratieve beroepen

Specialisten bedrijfsbeheer en administratie

Accountants

Financieel specialisten en economen

Bedrijfskundigen en organisatieadviseurs

Beleidsadviseurs

Specialisten personeels- en loopbaanontwikkeling

Vakspecialisten bedrijfsbeheer en administratie

Boekhouders

Zakelijke dienstverleners

Directiesecretaresses

Administratief personeel

Administratief medewerkers

Secretaresses

Receptionisten en telefonisten

Boekhoudkundig medewerkers

Transportplanners en logistiek medewerkers

Managers

Algemeen directeuren

Algemeen directeuren

Managers op administratief en commercieel gebied

Managers zakelijke en administratieve dienstverlening

Managers verkoop en marketing

Managers productie en gespecialiseerde dienstverlening

Managers productie

Managers logistiek

Managers ICT

Managers zorginstellingen

Managers onderwijs

Managers gespecialiseerde dienstverlening

Managers horeca, detailhandel en overige diensten

Managers horeca

Managers detail- en groothandel

Managers commerciële en persoonlijke dienstverlening

Managers z.n.d.

Managers z.n.d.

Openbaar bestuur, veiligheid en juridische beroepen

Overheidsambtenaren en -bestuurders 


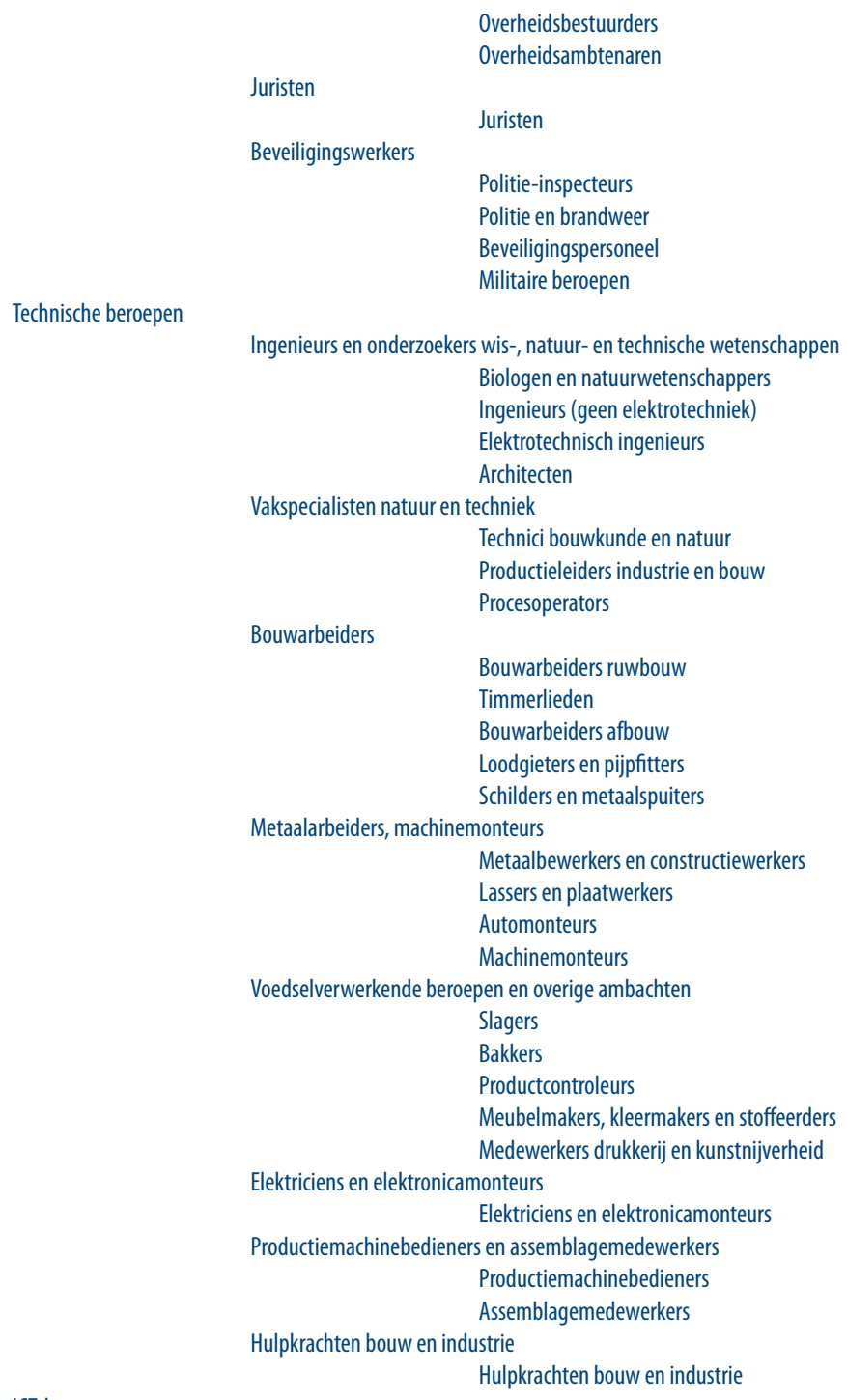

ICT-beroepen

Specialisten ICT

Software- en applicatieontwikkelaars

Databank- en netwerkspecialisten

Vakspecialisten ICT

Gebruikersondersteuning ICT

Radio- en televisietechnici

Agrarische beroepen

Tuinders, akkerbouwers en veetelers

Land- en bosbouwers

Hoveniers, tuinders en kwekers

Veetelers

Hulpkrachten landbouw 
Zorg- en welzijnberoepen

$$
\text { Hulpkrachten landbouw }
$$

Artsen, therapeuten en gespecialiseerd verpleegkundigen

Artsen

Gespecialiseerd verpleegkundigen

Fysiotherapeuten

Specialisten op maatschappelijk gebied

Maatschappelijk werkers

Vakspecialisten gezondheidszorg

Psychologen en sociologen

Laboranten

Apothekersassistenten

Verpleegkundigen (mbo)

Medisch praktijkassistenten

Medisch vakspecialisten

Sociaal werkers, groeps- en woonbegeleiders

Sociaal werkers, groeps- en woonbegeleiders

Verzorgenden

Verzorgenden

Dienstverlenende beroepen

Medewerkers persoonlijke dienstverlening

Reisbegeleiders

Koks

Kelners en barpersoneel

Kappers en schoonheidsspecialisten

Conciërges en teamleiders schoonmaak

Verleners van overige persoonlijke diensten

Schoonmakers en keukenhulpen

$$
\text { Schoonmakers }
$$

Keukenhulpen

Transport- en logistiek beroepen

Bestuurders voertuigen en bedieners mobiele machines

Dekofficieren en piloten

Chauffeurs auto's, taxi's en bestelwagens

Buschauffeurs en trambestuurders

Vrachtwagenchauffeurs

Bedieners mobiele machines

Hulpkrachten transport en logistiek

Laders, lossers en vakkenvullers

Vuilnisophalers en dagbladenbezorgers

Overig

Overig

Overig 
Opleidingsniveau, -sector, -subsector en onderliggende opleidingstypen

\section{ONR2019niveau}

\section{ONR2019sector}

ONR2019subsector

ONR2019type

Basisonderwijs

Basisonderwijs

Basisonderwijs

Basisonderwijs

Vmbo-b/k, mbo1

Vmbo-b/k, mbo1 - economie en maatschappij

Vmbo-b/k, mbo1 - economie en maatschappij

Vmbo-b/k, mbo1 - economie en maatschappij

Vmbo-b/k, mbo1 - landbouw en natuur

Vmbo-b/k, mbo1 - landbouw en natuur

Vmbo-b/k, mbo1 - landbouw en natuur

Vmbo-b/k, mbo1 - techniek en ict

Vmbo-b/k, mbo1 - techniek en ict

Vmbo-b/k, mbo1 - techniek en ict

Vmbo-b/k, mbo1 - zorg en dienstverlening

Vmbo-b/k, mbol - zorg en dienstverlening

Vmbo-b/k, mbo1 - zorg en dienstverlening

Vmbo-b/k, mbo1 - overig

Vmbo-b/k, mbo1 - overig

Vmbo-b/k, mbo1 - overig

Vmbo-g/t

Vmbo-g/t

Vmbo-g/t

Vmbo-g/t

Havo, vwo

Havo, vwo

Havo, vwo

Havo, vwo

Mbo2

Mbo2 - economie en maatschappij

Mbo2 - economie en maatschappij

Mbo2 - economie en maatschappij

Mbo2 - landbouw en natuur

Mbo2 - landbouw en natuur

Mbo2 - landbouw en natuur

Mbo2 - techniek en ict

Mbo2-techniek en ict

Mbo2 - techniek en ict

Mbo2 - zorg en dienstverlening

Mbo2 - zorg en dienstverlening

Mbo2 - zorg en dienstverlening

Mbo2 - overig

Mbo2 - overig

Mbo2 - overig 
Mbo3 - economie en maatschappij

Mbo3 - economie en administratie

Mbo3 - financieel-administratieve dienstverlening

Mbo3 - secretariële dienstverlening

Mb03 - handel, ondernemerschap, transport en logistiek

Mb03 - detailhandel en groothandel

Mbo3 - transport en logistiek

Mbo3 - landbouw en natuur

Mbo3 - voedsel, natuur en leefomgeving

Mbo3 - landbouw en dierverzorging

Mb03 - slagerij, bakkerij, versindustrie

Mbo3 - techniek en ict

Mbo3 - tuinbouw en groenvoorziening

Mbo3 - ict, media en vormgeving

Mbo3 - ict-ondersteuning

Mbo3 - mediatechniek

Mbo3 - techniek, bouw en procesindustrie

Mbo3 - bouw en infra

Mbo3 - elektro- en installatietechniek

Mbo3 - procestechniek en textiel

Mbo3 - werktuigbouwkunde en metaalbewerking

Mb03 - zorg en dienstverlening

Mbo3 - dienstverlening

Mbo3 - horeca

Mb03 - reiniging, sport en toerisme

Mbo3 - schoonheids- en haarverzorging

Mbo3 - veiligheid

Mbo3 - gezondheidszorg en welzijn

Mbo3 - laboratorium en gezondheidstechniek

Mbo3 - verzorgende ig

Mbo3 - overig

Mbo3-overig

Mbo3 - overig

Mbo4

Mbo4 - economie en maatschappij

Mbo4 - economie en administratie

Mbo4 - commerciële dienstverlening

Mbo4 - financieel-administratieve dienstverlening

Mbo4 - juridisch-administratieve dienstverlening

Mbo4 - secretariële en algemene administratieve dienstverlening

Mbo4 - handel, ondernemerschap, transport en logistiek

Mbo4 - management en ondernemerschap

Mbo4 - transport en logistiek

Mbo4 - landbouw en natuur

Mbo4 - voedsel, natuur en leefomgeving

Mbo4 - landbouw en dierverzorging

Mbo4 - slagerij, bakkerij, versindustrie

Mbo4 - techniek en ict

Mbo4 - tuinbouw en groenvoorziening

Mbo4 - ict, media en vormgeving

Mbo4 - ict- en mediabeheer

Mbo4 - mediavormgeving

Mbo4 - techniek, bouw en procesindustrie 
Mbo4 - bouw en infra

Mbo4 - elektro- en installatietechniek

Mbo4 - procestechniek en textiel

Mbo4 - werktuigbouwkunde en metaalbewerking

Mbo4 - zorg en dienstverlening

Mbo4 - dienstverlening

Mbo4 - facilitaire dienstverlening

Mbo4 - horeca

Mbo4 - schoonheids- en haarverzorging

Mb04 - sport en bewegen

Mbo4 - toerisme en recreatie

Mbo4 - gezondheidszorg en welzijn

Mbo4 - laboratorium en gezondheidstechniek

Mb04 - pedagogisch werk

Mbo4 - sociaal en maatschappelijk werk

Mbo4 - verpleegkunde en medische ondersteuning

Mbo4 - overig

Mbo4 - overig

Mbo4 - overig

Hbo-, wo-bachelor, Associate Degree (AD)

Bachelor - economie en maatschappij

Bachelor-dienstverlening

Bachelor - horeca, vrije tijd en faciliteitsmanagement

Bachelor - transport en logistiek

Bachelor-economie en recht

Bachelor - economie en econometrie

Bachelor - financieel management en fiscaal recht

Bachelor - management, bedrijfs- en personeelwetenschappen

Bachelor - marketing en public relations

Bachelor - recht

Bachelor - journalistiek, gedrag en maatschappij

Bachelor - communicatie en journalistiek

Bachelor - psychologie, sociale en maatschappijwetenschappen

Bachelor - kunst, taal en cultuur

Bachelor - kunst

Bachelor - taal en cultuur

Bachelor - landbouw en natuur

Bachelor - landbouw, wiskunde en natuurwetenschappen

Bachelor - landbouw, biologie en biochemische technologie

Bachelor - wis-, schei-, natuurkunde en geologie

Bachelor - techniek en ict

Bachelor-techniek en ict

Bachelor - bouwkunde, civiele techniek en architectuur

Bachelor - chemische technologie

Bachelor - elektrotechniek

Bachelor - informatica

Bachelor - werktuigbouwkunde

Bachelor - zorg en onderwijs

Bachelor - gezondheidszorg en welzijn

Bachelor - maatschappelijk werk

Bachelor - medische diagnostiek en medische technologie

Bachelor - sociaal pedagogisch werk

Bachelor - therapie en revalidatie

Bachelor - verpleeg- en verloskunde

Bachelor - onderwijs 
Bachelor - lerarenopleiding algemene en beroepsgerichte vakken Bachelor - lerarenopleiding basisonderwijs, speciaal onderwijs en basiseducatie

Bachelor - overig

Bachelor - onderwijskunde

Bachelor - overig

$$
\text { Bachelor - overig }
$$

Hbo-, wo-master, doctor

Master - economie en maatschappij

Master-economie en recht

Master - economie en econometrie

Master - financieel management en fiscaal recht

Master - management, bedrijfs- en personeelswetenschappen

Master - marketing en public relations

Master - recht

Master - journalistiek, gedrag en maatschappij

Master - communicatie en journalistiek

Master - psychologie

Master - sociale en maatschappijwetenschappen

Master - kunst, taal en cultuur

Master - kunst

Master - taal en cultuur

Master - landbouw en natuur

Master - landbouw, wiskunde en natuurwetenschappen

Master - landbouw, biologie en biochemische technologie

Master - wis-, schei-, natuurkunde en geologie

Master - techniek en ICT

Master-techniek en ICT

Master - bouwkunde, civiele techniek en architectuur

Master - chemische technologie

Master - elektrotechniek

Master - informatica

Master - zorg en onderwijs

Master - werktuigbouwkunde

Master - gezondheidszorg

Master - (dier)geneeskunde en tandheelkunde

Master - farmacie en gezondheidswetenschappen

Master - onderwijs

Master - lerarenopleiding algemene en beroepsgerichte vakken Master - onderwijskunde en pedagogische wetenschappen

\section{Master - overig}

Master-overig

Master - overig

\section{Onderwijs overig}

\section{Onderwijs overig}

Onderwijs overig

Onderwijs overig 


\section{BIJLAGE C:}

\section{VERKRIJGBARE ARBEIDSMARKT- INFORMATIE PER BEDRIJFSSECTOR, BEROEPSGROEP EN OPLEIDINGSTYPE}

Per bedrijfssector, beroepsgroep of opleidingstype (zie Bijlage B) zijn de hieronder weergegeven variabelen verkrijgbaar. De betreffende arbeidsmarktinformatie is afkomstig uit het Arbeidsmarktinformatiesysteem (AIS) van het ROA.

\begin{tabular}{|c|c|c|c|}
\hline Onderwerp & Sector & $\begin{array}{l}\text { Beroeps- } \\
\text { groep }\end{array}$ & $\begin{array}{l}\text { Opleidings- } \\
\text { type }\end{array}$ \\
\hline \multicolumn{4}{|c|}{ actuele arbeidsmarktinformatie, gemiddelde 2017-2018 } \\
\hline aantal - werkenden & $x$ & $x$ & $\mathrm{x}$ \\
\hline aantal - werkenden in arbeidsvolume & $x$ & $x$ & $x$ \\
\hline percentage - vrouwen & $x$ & $x$ & $x$ \\
\hline percentage - niet-westerse allochtonen & $x$ & $x$ & $x$ \\
\hline aantal - gemiddelde leeftijd & $x$ & $x$ & $x$ \\
\hline percentage - jongeren (15-29) & $x$ & $x$ & $\mathrm{x}$ \\
\hline percentage - ouderen (55-74) & $x$ & $x$ & $x$ \\
\hline percentage - vast dienstverband & $x$ & $x$ & $x$ \\
\hline percentage - flexibel werk & $x$ & $x$ & $x$ \\
\hline percentage - zelfstandig & $x$ & $x$ & $x$ \\
\hline aantal - gemiddeld aantal uren werk per week & $x$ & $x$ & $x$ \\
\hline percentage - deeltijd arbeid, minder dan 12 uur & $x$ & $x$ & $x$ \\
\hline percentage - deeltijd arbeid, 12 tot 20 uur & $x$ & $x$ & $x$ \\
\hline percentage - deeltijd arbeid, 20 tot 35 uur & $x$ & $x$ & $x$ \\
\hline percentage - voltijd arbeid, 35 uur en meer & $x$ & $x$ & $x$ \\
\hline percentage - overwerk & $x$ & $x$ & $\mathrm{x}$ \\
\hline percentage - midden- en kleinbedrijf & $x$ & $x$ & $x$ \\
\hline percentage - trainingsintensiteit, $<6$ maanden & $x$ & $x$ & $x$ \\
\hline percentage - trainingsintensiteit, $>=6$ maanden & $x$ & $x$ & $x$ \\
\hline percentage - student/scholier & $x$ & $x$ & $x$ \\
\hline aantal - potentiële beroepsbevolking & & & $x$ \\
\hline aantal - gemiddeld bruto uurloon (SSB2018) & & $x$ & $x$ \\
\hline aantal - loonrisico, aantal euro per uur & & $x$ & $x$ \\
\hline percentage - opleidingsachtergrond basisonderwijs & $x$ & $x$ & \\
\hline
\end{tabular}




\begin{tabular}{|c|c|c|c|}
\hline percentage - opleidingsachtergrond vmbo & $x$ & $x$ & \\
\hline percentage - opleidingsachtergrond vmbo $\mathrm{t} / \mathrm{gl}$ & $x$ & $x$ & \\
\hline percentage - opleidingsachtergrond havo/vwo & $x$ & $x$ & \\
\hline percentage - opleidingsachtergrond mbo 2 & $x$ & $x$ & \\
\hline percentage - opleidingsachtergrond mbo 3 & $x$ & $x$ & \\
\hline percentage - opleidingsachtergrond mbo 4 & $x$ & $\mathrm{x}$ & \\
\hline percentage - opleidingsachtergrond bachelor & $x$ & $x$ & \\
\hline percentage - opleidingsachtergrond master & $x$ & $\mathrm{x}$ & \\
\hline percentage - werkzame beroepsbevolking & & & $x$ \\
\hline percentage - werkloze beroepsbevolking & & & $\mathrm{x}$ \\
\hline percentage - bruto arbeidsparticipatie & & & $x$ \\
\hline percentage - netto arbeidsparticipatie & & & $\mathrm{x}$ \\
\hline \multicolumn{4}{|l|}{ arbeidsmarktprognoses tot 2024} \\
\hline percentage en aantal- verwachte uitbreidingsvraag tot 2024 & $x$ & $x$ & $x$ \\
\hline percentage en aantal- verwachte vervangingsvraag tot 2024 & & $x$ & $x$ \\
\hline percentage en aantal- verwachte baanopeningen tot 2024 & & $x$ & $\mathrm{x}$ \\
\hline percentage en aantal- verwachte instroom van gediplomeerden tot 2024 & & & $x$ \\
\hline indicator - ITKB toekomstige knelpunten beroepsgroep in 2024 & & $\mathrm{x}$ & \\
\hline indicator - ITKP toekomstige knelpunten personeelsvoorziening in 2024 & & & $x$ \\
\hline indicator - ITA toekomstige arbeidsmarktsituatie in 2024 & & & $\mathrm{x}$ \\
\hline indicator - loopbaanperspectief & & $x$ & $x$ \\
\hline indicator - uitwijkmogelijkheden naar beroepsgroep & $x$ & & $\mathrm{x}$ \\
\hline indicator - uitwijkmogelijkheden naar sector & & $x$ & $x$ \\
\hline indicator - substitutiemogelijkheden naar opleidingstype & & $x$ & \\
\hline indicator - conjunctuurgevoeligheid & $x$ & $x$ & $x$ \\
\hline indicator - concurrentieindex naar opleiding & & & $\mathrm{x}$ \\
\hline
\end{tabular}

\section{arbeidsmarktuitkomsten 2017}

\begin{tabular}{|c|c|c|}
\hline percentage en aantal- Werknemer & & $x$ \\
\hline percentage en aantal-Zelfstandig & & $x$ \\
\hline percentage en aantal- Uitkering & & $x$ \\
\hline percentage en aantal-Student/Scholier & & $x$ \\
\hline percentage en aantal- Overig & & $x$ \\
\hline aantal - Werknemer, gemiddeld bruto uurloon (SBB2018) & & $x$ \\
\hline \multicolumn{3}{|l|}{ actuele arbeidsmarktinformatie, gemiddelde 2017-2018 } \\
\hline percentage - belangrijkste beroep per opleiding, gemiddelde 2017-2018 & & $x$ \\
\hline percentage - belangrijkste sector per opleiding, gemiddelde 2017-2018 & & $x$ \\
\hline percentage - belangrijkste opleiding per beroep, gemiddelde 2017-2018 & $x$ & \\
\hline percentage - belangrijkste sector per beroep, gemiddelde 2017-2018 & $x$ & \\
\hline
\end{tabular}




\begin{tabular}{|l|l|l|}
\hline percentage - belangrijkste opleiding per sector, gemiddelde 2017-2018 & $\mathrm{x}$ \\
\hline percentage - belangrijkste beroep per sector, gemiddelde 2017-2018 & $\mathrm{X}$ & \\
\hline schoolverlatersgegevens 2018 & & $\mathrm{X}$ \\
\hline percentage - participatie in vervolgopleiding, studie & $\mathrm{x}$ \\
\hline percentage - participatie in vervolgopleiding, BBL & $\mathrm{x}$ \\
\hline percentage - werkloosheid & $\mathrm{x}$ \\
\hline percentage - intredewerkloosheid van 4 maanden of langer & $\mathrm{x}$ \\
\hline percentage - vast dienstverband & $\mathrm{x}$ \\
\hline percentage - flexibel werk & $\mathrm{x}$ \\
\hline percentage - deeltijd arbeid, minder dan 12 uur & $\mathrm{x}$ \\
\hline percentage - deeltijd arbeid, 12 tot 20 uur & $\mathrm{x}$ \\
\hline percentage - deeltijd arbeid, 20 tot 35 uur & & $\mathrm{x}$ \\
\hline percentage - voltijd arbeid, 35 uur en meer & & $\mathrm{x}$ \\
\hline aantal - gemiddelde leeftijd & $\mathrm{x}$ \\
\hline percentage - buiten de vakrichting & \\
\hline percentage - onderbenutting & $\mathrm{x}$ \\
\hline percentage - spijt van de gevolgde opleiding & $\mathrm{x}$ \\
\hline aantal - gemiddeld bruto maandloon & $\mathrm{x}$ \\
\hline aantal - gemiddeld aantal uren per week & $\mathrm{x}$ \\
\hline percentage - midden- en klein bedrijf & $\mathrm{x}$ \\
\hline percentage - niet-westerse allochtonen & $\mathrm{x}$ \\
\hline
\end{tabular}

leerlingen 2018-2019 en gediplomeerden 2017-2018

\begin{tabular}{|l|l|l|}
\hline aantal - leerlingen & $\mathrm{x}$ \\
\hline percentage en aantal- leerlingen - vrouw & $\mathrm{x}$ \\
\hline percentage en aantal- leerlingen - BBL & $\mathrm{x}$ \\
\hline percentage en aantal- leerlingen - deeltijd/duaal in hoger onderwijs & $\mathrm{x}$ \\
\hline aantal - gediplomeerden & $\mathrm{x}$ \\
\hline percentage en aantal- gediplomeerden - vrouw & $\mathrm{x}$ \\
\hline percentage en aantal- gediplomeerden - BBL & $\mathrm{x}$ \\
\hline percentage en aantal- gediplomeerden - deeltijd/duaal in hoger onderwijs & $\mathrm{x}$ \\
\hline
\end{tabular}

vacaturegegevens 2017-2018

\begin{tabular}{|l|l|l|}
\hline percentage - vacatures & $\mathrm{x}$ & $\mathrm{x}$ \\
\hline percentage - bedrijven met vacatures & $\mathrm{x}$ \\
\hline percentage - bedrijven met vacatures - langer dan 3 maanden open & $\mathrm{x}$ \\
\hline percentage - bedrijven met vacatures - moeilijk vervulbaar & \\
\hline arbeidsomstandigheden 2016 & $\mathrm{x}$ \\
\hline percentage - stank, lawaai, tocht of hoge/lage temperaturen & $\mathrm{x}$ \\
\hline percentage - werken met gevaarlijke stoffen & \\
\hline
\end{tabular}




\begin{tabular}{|l|l|l|}
\hline percentage - werken onder gevaarlijke omstandigheden & $\mathrm{x}$ \\
\hline percentage - lichamelijk zwaar werk & $\mathrm{x}$ \\
\hline percentage - geestelijk zwaar werk & $\mathrm{x}$ \\
\hline percentage - emotioneel zwaar werk & $\mathrm{x}$ \\
\hline percentage - agressie op de werkplek & $\mathrm{x}$ \\
\hline percentage - herhaling van dezelfde eenvoudige werkzaamheden & $\mathrm{x}$ \\
\hline percentage - werken met mensen (patiënten, cliënten, enz.) & $\mathrm{x}$ \\
\hline percentage - werk buiten mijn vak of beroep & $\mathrm{x}$ \\
\hline percentage - zelf begintijd of eindtijd bepalen & $\mathrm{x}$ \\
\hline percentage - werk in ploegendienst of wisselende diensten & $\mathrm{x}$ \\
\hline percentage - werk met onregelmatige werktijd, door werkgever/opdrachtgever & $\mathrm{x}$ \\
\hline percentage - werken in nachtdienst & $\mathrm{x}$ \\
\hline percentage - werken op zaterdag & $\mathrm{x}$ \\
\hline percentage - werken op zondag & $\mathrm{x}$ \\
\hline percentage - zelf bepalen waar u werkt (thuis, werkg/opdrachtgever,elders) & $\mathrm{x}$ \\
\hline
\end{tabular}

\section{verwachte knelpunten}

\begin{tabular}{|c|c|c|}
\hline indicator - knelpunten in de personeelsvoorziening naar bedrijfssector in 2024 & $x$ & \\
\hline indicator - knelpunten in de beroepsgroepen naar bedrijfssector in 2024 & $x$ & \\
\hline \multicolumn{3}{|l|}{ kernvaardigheden 2012} \\
\hline percentage - gebruikt computer op het werk & $\mathrm{x}$ & $x$ \\
\hline score - taalvaardigheid & $x$ & $x$ \\
\hline score - rekenvaardigheid & $x$ & $x$ \\
\hline score - probleemoplossend vermogen in digitale omgevingen & $x$ & $x$ \\
\hline
\end{tabular}

\section{kerncijfers gediplomeerden 2016-2017}

\begin{tabular}{|c|c|}
\hline percentage - Vrouw (\%) & $\mathrm{x}$ \\
\hline aantal-Gemiddelde leeftijd & $x$ \\
\hline percentage - Westerse allochtoon (\%) & $x$ \\
\hline percentage - Niet westerse allochtoon (\%) & $x$ \\
\hline aantal - Gewogen aantal & $x$ \\
\hline aantal - Ongewogen aantal & $x$ \\
\hline percentage - Vooropleiding HAVO (\%) & $x$ \\
\hline percentage - Vooropleiding VW0 (\%) & $x$ \\
\hline percentage - Vooropleiding BOL/BBL (\%) & $x$ \\
\hline percentage - Vooropleiding: HBO (\%) & $x$ \\
\hline percentage - Vooropleiding: W0 (\%) & $\mathrm{x}$ \\
\hline percentage - Vooropleiding: anders (\%) & $x$ \\
\hline $\begin{array}{l}\text { aantal - Studieduur van de opleiding in maanden (inclusief eventuele } \\
\text { onderbrekingen) }\end{array}$ & $x$ \\
\hline
\end{tabular}




\begin{tabular}{|c|c|}
\hline aantal - Gemiddeld examencijfer opleiding & $x$ \\
\hline percentage - Profiel: cultuur en maatschappij (\%) & $x$ \\
\hline percentage - Profiel: economie en maatschappij (\%) & $\mathrm{x}$ \\
\hline percentage - Profiel: natuur en gezondheid (\%) & $x$ \\
\hline percentage - Profiel: natuur en techniek (\%) & $\mathrm{x}$ \\
\hline percentage - Profiel: combinatieprofiel (\%) & $x$ \\
\hline percentage - Tijdens opleiding stage in Nederland gelopen (\%) & $x$ \\
\hline percentage - Tijdens opleiding stage in buitenland gelopen (\%) & $x$ \\
\hline percentage - Tijdens opleiding relevante werkervaring opgedaan (\%) & $x$ \\
\hline percentage - Tijdens opleiding onderwijs in buitenland gevolgd (\%) & $x$ \\
\hline percentage - Tijdens opleiding bestuurlijke ervaring opgedaan (\%) & $\mathrm{x}$ \\
\hline percentage - Tijdens opleiding eigen bedrijf opgericht (\%) & $x$ \\
\hline percentage - Tevreden over geleerde vaardigheden (\%) & $x$ \\
\hline percentage - Tevreden over de sfeer op school (\%) & $x$ \\
\hline percentage - Tevreden over de manier waarop leraren les gaven (\%) & $x$ \\
\hline percentage - Tevreden over de kwaliteit van de docenten (\%) & $x$ \\
\hline percentage - Tevreden over verhouding theorie/praktijk (\%) & $\mathrm{x}$ \\
\hline percentage - Tevreden over de inhoud van de vakken (\%) & $x$ \\
\hline percentage - Tevreden over de (studie)begeleiding (\%) & $\mathrm{x}$ \\
\hline percentage - Tevreden over de manier van examineren (\%) & $x$ \\
\hline percentage - Tevreden over de kwaliteit van de examens (\%) & $\mathrm{x}$ \\
\hline percentage - Tevreden over de huisvesting van de gevolgde opleiding (\%) & $x$ \\
\hline percentage - Tevreden over de materiële schoolvoorzieningen (\%) & $\mathrm{x}$ \\
\hline percentage - Oordeel over breedte opleiding: te smal (\%) & $x$ \\
\hline percentage - Oordeel over breedte opleiding: te breed (\%) & $\mathrm{x}$ \\
\hline percentage - Oordeel over diepgang opleiding: te weinig diepgang (\%) & $x$ \\
\hline percentage - Oordeel over diepgang opleiding: te veel diepgang (\%) & $x$ \\
\hline percentage - Oordeel over moeilijkheidsgraad opleiding: te laag (\%) & $x$ \\
\hline percentage - Oordeel over moeilijkheidsgraad opleiding: te hoog (\%) & $x$ \\
\hline percentage - Oordeel over opleiding: te theoretisch (\%) & $x$ \\
\hline percentage - Oordeel over opleiding: te praktijkgericht (\%) & $\mathrm{x}$ \\
\hline percentage - Oordeel over keuzemogelijkheden opleiding: te weinig (\%) & $x$ \\
\hline percentage - Oordeel over keuzemogelijkheden opleiding: te veel (\%) & $x$ \\
\hline percentage - Oordeel over opleiding: docenten streng in de beoordeling (\%) & $x$ \\
\hline percentage - 0ordeel over opleiding: niveau van de leerstof was goed (\%) & $x$ \\
\hline percentage - Oordeel over opleiding: uitdagend qua niveau (\%) & $x$ \\
\hline $\begin{array}{l}\text { percentage - Oordeel over opleiding: moeilijk om bij groepsopdrachten mee te liften } \\
\text { (\%) }\end{array}$ & $x$ \\
\hline
\end{tabular}




\begin{tabular}{|c|c|}
\hline percentage - Oordeel over opleiding: beoordelingscriteria vooraf duidelijk (\%) & $\mathrm{x}$ \\
\hline $\begin{array}{l}\text { percentage - Oordeel over opleiding: beoordelingscriteria alle studenten op gelijke } \\
\text { wijze (\%) }\end{array}$ & $\mathrm{x}$ \\
\hline percentage - Oordeel over opleiding: toetsen en opdrachten van hoog niveau (\%) & $\mathrm{x}$ \\
\hline percentage - Oordeel over opleiding: examens in het algemeen zeer pittig (\%) & $x$ \\
\hline percentage - Oordeel over opleiding: voldoende getoetst op inzicht (\%) & $x$ \\
\hline percentage - Tevredenheid over inhoudelijke samenhang van de opleiding (\%) & $x$ \\
\hline percentage - Tevredenheid over actualiteit inhoud van de opleiding (\%) & $x$ \\
\hline percentage - Tevredenheid over internationale orientatie opleiding (\%) & $\mathrm{x}$ \\
\hline percentage - Tevredenheid over inbedding praktijkgericht onderzoek in opleiding (\%) & $x$ \\
\hline percentage - Tevredenheid over actuele kennis docenten over beroepspraktijk (\%) & $\mathrm{x}$ \\
\hline percentage - Tevredenheid over betrokkenheid van docenten (\%) & $x$ \\
\hline percentage - Tevredenheid over inspirerend vermogen docenten (\%) & $x$ \\
\hline percentage - Tevredenheid over inhoudsdeskundigheid docenten (\%) & $x$ \\
\hline percentage - Tevredenheid over didactische vaardigheden docenten (\%) & $x$ \\
\hline $\begin{array}{l}\text { percentage - Tevredenheid over voorlichting studiemogelijkheden in } \\
\text { vervolgonderwijs (\%) }\end{array}$ & $\mathrm{x}$ \\
\hline percentage - Tevredenheid over voorlichting beroepsmogelijkheden (\%) & $\mathrm{x}$ \\
\hline percentage - Tevredenheid over studiebegeleiding tijdens opleiding (\%) & $x$ \\
\hline percentage - Onderwijsmethoden geschikt bij voorbereiding beroepsloopbaan (\%) & $\mathrm{x}$ \\
\hline $\begin{array}{l}\text { percentage - Tevreden met begeleiding vanuit school tijdens stage/ } \\
\text { beroepspraktijkvorming (\%) }\end{array}$ & $\mathrm{x}$ \\
\hline $\begin{array}{l}\text { percentage - Tevreden met begeleiding vanuit stageplaats/beroepspraktijkvorming } \\
\text { (\%) }\end{array}$ & $x$ \\
\hline percentage - Opnieuw kiezen voor dezelfde opleiding (\%) & $\mathrm{x}$ \\
\hline percentage - Tevreden over studie in het algemeen (\%) & $\mathrm{x}$ \\
\hline percentage - Tevreden over voorbereiding beroepsloopbaan (\%) & $x$ \\
\hline percentage - Opleiding goede basis om te starten op de arbeidsmarkt (\%) & $x$ \\
\hline $\begin{array}{l}\text { percentage - Opleiding goede basis om kennis en vaardigheden verder te } \\
\text { ontwikkelen (\%) }\end{array}$ & $x$ \\
\hline percentage - Opleiding goede basis om een vervolgopleiding te kiezen (\%) & $x$ \\
\hline percentage - Opleiding goede basis om een vervolgopleiding te volgen (\%) & $\mathrm{x}$ \\
\hline percentage - Na de opleiding doorgestroomd naar vervolgonderwijs (\%) & $\mathrm{x}$ \\
\hline percentage - Vervolgopleiding op AV0 niveau (\%) & $x$ \\
\hline percentage - Vervolgopleiding op VMBO niveau (\%) & $x$ \\
\hline percentage - Vervolgopleiding op BOL niveau 1/2 (\%) & $x$ \\
\hline percentage - Vervolgopleiding op BOL niveau 3/4 (\%) & $x$ \\
\hline percentage - Vervolgopleiding op BBL niveau (\%) & $x$ \\
\hline percentage - Vervolgopleiding op HBO niveau (\%) & $x$ \\
\hline percentage - Vervolgopleiding op W0 niveau (\%) & $x$ \\
\hline
\end{tabular}




\begin{tabular}{|c|c|}
\hline percentage - Volgt vervolgopleiding nog steeds (\%) & $\mathrm{x}$ \\
\hline percentage - Diploma of certificaat van vervolgopleiding behaald (\%) & $x$ \\
\hline percentage - Vervolgopleiding zonder diploma verlaten (\%) & $\mathrm{x}$ \\
\hline percentage - Redelijk tot goede aansluiting tussen gevolgde en vervolgopleiding (\%) & $x$ \\
\hline percentage - Tevredenheid voorbereiding op vervolgopleiding (\%) & $\mathrm{x}$ \\
\hline percentage - Opleiding goede voorbereiding voor vervolgopleiding (\%) & $x$ \\
\hline percentage - Opnieuw kiezen voor dezelfde vervolgopleiding (\%) & $\mathrm{x}$ \\
\hline percentage - Cursus of bedrijfsopleiding gevolgd (\%) & $\mathrm{x}$ \\
\hline aantal - Gewogen aantal: vervolgonderwijs & $x$ \\
\hline aantal - Ongewogen aantal: vervolgonderwijs & $x$ \\
\hline percentage - Aanbieden op arbeidsmarkt (\%) & $\mathrm{x}$ \\
\hline percentage - Werkloosheid (\%) & $x$ \\
\hline percentage - Aansluiting van opleiding met huidige functie is voldoende/goed (\%) & $\mathrm{x}$ \\
\hline aantal - Aantal maanden werkloos voor eerste baan & $x$ \\
\hline percentage - Vaste aanstelling bij huidige functie (\%) & $\mathrm{x}$ \\
\hline percentage - Flexibele arbeidsrelatie in huidige functie (\%) & $x$ \\
\hline percentage - Dienstverband huidige functie: uitzendkracht, oproepkracht (\%) & $\mathrm{x}$ \\
\hline percentage - Dienstverband huidige functie: in loondienst (\%) & $x$ \\
\hline percentage - Dienstverband huidige functie: leer-/arbeidsovereenkomst (\%) & $\mathrm{x}$ \\
\hline percentage - Dienstverband huidige functie: zelfstandige/freelance (\%) & $x$ \\
\hline percentage - Dienstverband huidige functie: anders (\%) & $\mathrm{x}$ \\
\hline percentage - Fulltime baan (meer dan 32 uur per week) (\%) & $x$ \\
\hline percentage - Leidinggevende functie (\%) & $x$ \\
\hline $\begin{array}{l}\text { percentage - Werkzaam in MKB (personeelsomvang minder dan } 250 \text { werknemers) } \\
(\%)\end{array}$ & $\mathrm{x}$ \\
\hline percentage - Huidige functie op minimaal eigen opleidingsniveau (\%) & $\mathrm{x}$ \\
\hline percentage - Huidige functie binnen eigen of verwante opleidingsrichting (\%) & $x$ \\
\hline $\begin{array}{l}\text { percentage - Geografische mobiliteit (opleiding-werkzaam) zelfde/aangrenzende } \\
\text { provincie (\%) }\end{array}$ & $\mathrm{x}$ \\
\hline aantal - Aantal arbeidsuren per week in huidige functie (excl. overwerk) & $\mathrm{x}$ \\
\hline aantal - Bruto maandinkomen huidige functie (euro) & $x$ \\
\hline aantal - Bruto uurinkomen huidige functie (euro) & $x$ \\
\hline percentage - Kennis en vaardigheden worden benut in huidige functie (\%) & $x$ \\
\hline percentage - Kennis en vaardigheden schieten tekort voor huidige functie (\%) & $x$ \\
\hline percentage - Huidige functie biedt (veel) goede carriéremogelijkheden (\%) & $\mathrm{x}$ \\
\hline percentage - Tevreden met huidige functie (\%) & $x$ \\
\hline aantal - Gewogen aantal: beroepsbevolking & $\mathrm{x}$ \\
\hline aantal - Ongewogen aantal: beroepsbevolking & $x$ \\
\hline
\end{tabular}




\begin{tabular}{|c|c|}
\hline percentage - Vereist niveau functie - Kennis van eigen vakgebied (\%) & $x$ \\
\hline percentage - Vereist niveau functie - Kennis van andere vakgebieden (\%) & $x$ \\
\hline $\begin{array}{l}\text { percentage - Vereist niveau functie - Methoden en technieken praktijkgericht } \\
\text { onderzoek (\%) }\end{array}$ & $\mathrm{x}$ \\
\hline $\begin{array}{l}\text { percentage - Vereist niveau functie - Vermogen om vakkennis in de praktijk toe te } \\
\text { passen (\%) }\end{array}$ & $\mathrm{x}$ \\
\hline $\begin{array}{l}\text { percentage - Vereist niveau functie - Vermogen om informatie- \& } \\
\text { communicatietechnologie te gebruiken }(\%)\end{array}$ & $x$ \\
\hline percentage - Vereist niveau functie - Vermogen om informatie te vergaren (\%) & $x$ \\
\hline $\begin{array}{l}\text { percentage - Vereist niveau functie -Vermogen om problemen en kansen te } \\
\text { signaleren (\%) }\end{array}$ & $x$ \\
\hline percentage - Vereist niveau functie - Vermogen om logisch te redeneren (\%) & $x$ \\
\hline $\begin{array}{l}\text { percentage - Vereist niveau functie - Vermogen om conform budget, planning of } \\
\text { richtlijnen te werken (\%) }\end{array}$ & $x$ \\
\hline $\begin{array}{l}\text { percentage - Vereist niveau functie - Vermogen om nieuwe ideeën en oplossingen te } \\
\text { bedenken (\%) }\end{array}$ & $x$ \\
\hline percentage - Vereist niveau functie - Vermogen om nieuwe dingen te leren (\%) & $\mathrm{x}$ \\
\hline $\begin{array}{l}\text { percentage - Vereist niveau functie - Vermogen om aan anderen duidelijk te maken } \\
\text { wat men bedoelt (\%) }\end{array}$ & $x$ \\
\hline $\begin{array}{l}\text { percentage - Vereist niveau functie - Vermogen om productief met anderen samen } \\
\text { te werken (\%) }\end{array}$ & $x$ \\
\hline $\begin{array}{l}\text { percentage - Vereist niveau functie - Vermogen om zelfstandig de werkzaamheden } \\
\text { uit te voeren (\%) }\end{array}$ & $x$ \\
\hline percentage - Vereist niveau functie - Vermogen om analytisch te denken (\%) & $x$ \\
\hline $\begin{array}{l}\text { percentage - Vereist niveau functie - vermogen om praktijkgericht onderzoek kritisch } \\
\text { te beoordelen (\%) }\end{array}$ & $x$ \\
\hline $\begin{array}{l}\text { percentage - Vereist niveau functie - Vermogen om schriftelijk te rapporteren over } \\
\text { praktijkgericht onderzoek (\%) }\end{array}$ & $x$ \\
\hline percentage - Vereist niveau functie - Vakkennis (\%) & $x$ \\
\hline $\begin{array}{l}\text { percentage - Vereist niveau functie - Inzicht in informatie- \& } \\
\text { communicatietechnologie (\%) }\end{array}$ & $x$ \\
\hline percentage - Vereist niveau functie - Inzicht in bedrijfsvoering (\%) & $x$ \\
\hline percentage - Vereist niveau functie - Vreemde talen (\%) & $x$ \\
\hline percentage - Vereist niveau functie - Inzicht in milieu- en veiligheidsvoorschriften (\%) & $x$ \\
\hline $\begin{array}{l}\text { percentage - Vereist niveau functie - Toepassen van kennis en technieken in de } \\
\text { parktijk (\%) }\end{array}$ & $x$ \\
\hline percentage - Vereist niveau functie - Schrijfvaardigheid (\%) & $x$ \\
\hline percentage - Vereist niveau functie - Spreekvaardigheid (\%) & $x$ \\
\hline percentage - Vereist niveau functie - Rekenvaardigheid (\%) & $x$ \\
\hline percentage - Vereist niveau functie - Overdragen van kennis (\%) & $x$ \\
\hline $\begin{array}{l}\text { percentage - Vereist niveau functie - Plannen, coördineren, organiseren van } \\
\text { activiteiten (\%) }\end{array}$ & $x$ \\
\hline
\end{tabular}




\begin{tabular}{|c|c|}
\hline percentage - Vereist niveau functie - Oplossen van problemen (\%) & $x$ \\
\hline percentage - Vereist niveau functie - Contactuele vaardigheden (\%) & $x$ \\
\hline percentage - Vereist niveau functie - Werken in teamverband/ samenwerken (\%) & $x$ \\
\hline $\begin{array}{l}\text { percentage - Vereist niveau functie - Commerciële vaardigheden/zelfstandig } \\
\text { ondernemerschap (\%) }\end{array}$ & $\mathrm{x}$ \\
\hline percentage - Vereist niveau functie - Zelfstandigheid (\%) & $x$ \\
\hline percentage - Vereist niveau functie - Initiatief, creativiteit (\%) & $x$ \\
\hline percentage - Vereist niveau functie - Aanpassingsvermogen (\%) & $\mathrm{x}$ \\
\hline percentage - Vereist niveau functie - Nauwkeurigheid, zorgvuldigheid (\%) & $x$ \\
\hline percentage - Vereist niveau functie - Zelfstandig ondernemerschap (\%) & $x$ \\
\hline percentage - Vereist niveau functie - Maatschappelijke betrokkenheid (\%) & $x$ \\
\hline percentage - Vereist niveau functie - Aandacht voor duurzaamheid (\%) & $x$ \\
\hline percentage - Eigen niveau - Kennis van eigen vakgebied (\%) & $x$ \\
\hline percentage - Eigen niveau - Kennis van andere vakgebieden (\%) & $x$ \\
\hline percentage - Eigen niveau - Methoden en technieken praktijkgericht onderzoek (\%) & $\mathrm{x}$ \\
\hline percentage - Eigen niveau - Vermogen om vakkennis in de praktijk toe te passen (\%) & $x$ \\
\hline $\begin{array}{l}\text { percentage - Eigen niveau - Vermogen om informatie- \& communicatietechnologie } \\
\text { te gebruiken (\%) }\end{array}$ & $\mathrm{x}$ \\
\hline percentage - Eigen niveau - Vermogen om informatie te vergaren (\%) & $x$ \\
\hline percentage - Eigen niveau - Vermogen om problemen en kansen te signaleren (\%) & $x$ \\
\hline percentage - Eigen niveau - Vermogen om logisch te redeneren (\%) & $\mathrm{x}$ \\
\hline $\begin{array}{l}\text { percentage - Eigen niveau - Vermogen om conform budget, planning of richtlijnen } \\
\text { te werken (\%) }\end{array}$ & $x$ \\
\hline $\begin{array}{l}\text { percentage - Eigen niveau - Vermogen om nieuwe ideeën en oplossingen te } \\
\text { bedenken (\%) }\end{array}$ & $x$ \\
\hline percentage - Eigen niveau - Vermogen om nieuwe dingen te leren (\%) & $x$ \\
\hline $\begin{array}{l}\text { percentage - Eigen niveau - Vermogen om aan anderen duidelijk te maken wat men } \\
\text { bedoelt (\%) }\end{array}$ & $\mathrm{x}$ \\
\hline $\begin{array}{l}\text { percentage - Eigen niveau - Vermogen om productief met anderen samen te werken } \\
\text { (\%) }\end{array}$ & $x$ \\
\hline $\begin{array}{l}\text { percentage - Eigen niveau - Vermogen om zelfstandig de werkzaamheden uit te } \\
\text { voeren (\%) }\end{array}$ & $x$ \\
\hline percentage - Eigen niveau - Vermogen om analytisch te denken (\%) & $x$ \\
\hline $\begin{array}{l}\text { percentage - Eigen niveau - Vermogen om praktijkgericht onderzoek kritisch te } \\
\text { beoordelen (\%) }\end{array}$ & $x$ \\
\hline $\begin{array}{l}\text { percentage - Eigen niveau - Vermogen om schriftelijk te rapporteren over } \\
\text { praktijkgericht onderzoek (\%) }\end{array}$ & $x$ \\
\hline percentage - Eigen niveau - Vakkennis (\%) & $x$ \\
\hline percentage - Eigen niveau - Inzicht in informatie- \& communicatietechnologie (\%) & $x$ \\
\hline percentage - Eigen niveau - Inzicht in bedrijfsvoering (\%) & $x$ \\
\hline percentage - Eigen niveau - Vreemde talen (\%) & $x$ \\
\hline
\end{tabular}




\begin{tabular}{l|l|l}
\hline $\begin{array}{l}\text { percentage - Eigen niveau - Inzicht in milieu- en veiligheidsvoorschriften (\%) } \\
\text { percentage - Eigen niveau - Toepassen van kennis en technieken in de parktijk (\%) }\end{array}$ & $\mathrm{x}$ \\
\hline $\begin{array}{l}\text { percentage - Eigen niveau - Schrijfvaardigheid (\%) } \\
\text { percentage - Eigen niveau - Spreekvaardigheid (\%) }\end{array}$ & $\mathrm{x}$ \\
\hline $\begin{array}{l}\text { percentage - Eigen niveau - Rekenvaardigheid (\%) } \\
\text { percentage - Eigen niveau - Overdragen van kennis (\%) }\end{array}$ & $\mathrm{x}$ \\
\hline $\begin{array}{l}\text { percentage - Eigen niveau - Plannen, coördineren, organiseren van activiteiten (\%) } \\
\text { percentage - Eigen niveau - Oplossen van problemen (\%) }\end{array}$ & $\mathrm{x}$ \\
\hline $\begin{array}{l}\text { percentage - Eigen niveau - Contactuele vaardigheden (\%) } \\
\text { percentage - Eigen niveau - Werken in teamverband/samenwerken (\%) }\end{array}$ & $\mathrm{x}$ \\
\hline $\begin{array}{l}\text { percentage - Eigen niveau - Commerciële vaardigheden/zelfstandig } \\
\text { ondernemerschap (\%) }\end{array}$ & $\mathrm{x}$ \\
\hline percentage - Eigen niveau - Zelfstandigheid (\%) & $\mathrm{x}$ \\
\hline percentage - Eigen niveau - Initiatief, creativiteit (\%) & $\mathrm{x}$ \\
\hline percentage - Eigen niveau - Aanpassingsvermogen (\%) & $\mathrm{x}$ \\
\hline percentage - Eigen niveau - Nauwkeurigheid, zorgvuldigheid (\%) & \\
\hline percentage - Eigen niveau - Zelfstandig ondernemerschap (\%) & $\mathrm{x}$ \\
\hline percentage - Eigen niveau - Maatschappelijke betrokkenheid (\%) & $\mathrm{x}$ \\
\hline percentage - Eigen niveau - Aandacht voor duurzaamheid (\%) & $\mathrm{x}$ \\
\hline & $\mathrm{x}$ \\
\hline & $\mathrm{x}$ \\
\hline
\end{tabular}




\section{BIJLAGE D: \\ AANSLUITINGSINDICATOREN RECENT GEDIPLOMEERDEN}

De aansluitingsindicatoren voor recent gediplomeerden uit het mbo en hbo hebben betrekking op jongeren die in het school-/academisch jaar 2016/2017 hun diploma hebben behaald en eind 2018 geënquêteerd zijn, ongeveer anderhalf jaar na het afronden van hun opleiding. De cijfers zijn afkomstig uit het SchoolverlatersInformatieSysteem (SIS). ${ }^{66}$ De cijfers voor wo-gediplomeerden zijn afkomstig uit de Nederlandse Alumni Enquête, en hebben betrekking op gediplomeerden die in 2017 zijn geënquêteerd (gediplomeerd in jaar 2015/2016). ${ }^{67}$

De cijfers die worden gepresenteerd betreffen enkel gediplomeerden die zich aanbieden op de arbeidsmarkt. ${ }^{68}$ Dit kunnen dus ook gediplomeerden zijn die een vervolgopleiding volgen en daarnaast een bijbaan hebben. Voor de verschillende opleidingssubsectoren wordt de kwaliteit van de aansluiting tussen het onderwijs en de arbeidsmarkt gemeten aan de hand van de volgende indicatoren: werkloosheid, loon onder het gemiddelde van het opleidingsniveau, werken onder het opleidingsniveau of buiten de opleidingsrichting, en het aandeel kleine banen (tussen 1 en 20 uur).

66 https://roa.maastrichtuniversity.nl/research/research-projects/schoolverlatersonderzoeken-school-leaversurveys

67 https://www.vsnu.nl/nae.html De cijfers voor 2017 zijn de meest recent beschikbaar.

68 Het behalen van een diploma is voor veel gediplomeerden geen eindstation. Een aanzienlijk deel studeert door, al verschilt dit sterk naar opleidingsniveau en -richting (ROA (2017). Schoolverlaters tussen onderwijs en arbeidsmarkt 2016. ROA-R-2017/7). 
TABEL D.1

Aansluitingsindicatoren gediplomeerden naar ONR2019subsector , 2016/2017 ${ }^{1}$

\begin{tabular}{|c|c|c|c|c|c|}
\hline & $\begin{array}{c}\text { Werkloos- } \\
\text { heid } \\
\%\end{array}$ & $\begin{array}{c}\text { Percentage } \\
\text { loon onder } \\
\text { gemiddeld } \\
€\end{array}$ & $\begin{array}{c}\text { Onder- } \\
\text { benutting } \\
\%\end{array}$ & $\begin{array}{c}\text { Buiten eigen/ } \\
\text { verwante richting } \\
\%\end{array}$ & $\begin{array}{c}\text { Kleine } \\
\text { baan } \\
\%\end{array}$ \\
\hline Mbo2 - economie en maatschappij & 5,5 & 63,6 & 32,6 & 54,3 & 16,4 \\
\hline Mbo2 - landbouw en natuur & 3,9 & 70,9 & 28,5 & 45,7 & 6,0 \\
\hline Mbo2 - techniek en ict & 2,4 & 54,9 & 19,2 & 28,8 & 4,5 \\
\hline Mbo2 - zorg en dienstverlening & 3,4 & 57,1 & 26,6 & 45,1 & 15,5 \\
\hline Mbo3 - economie en maatschappij & 4,2 & 75,2 & 32,7 & 46,9 & 7,0 \\
\hline Mbo3 - landbouw en natuur & 3,3 & 78,2 & 34,8 & 40,3 & 6,9 \\
\hline Mbo3 - techniek en ict & 2,4 & 60,9 & 30,3 & 26,3 & 3,7 \\
\hline Mb03 - zorg en dienstverlening & 1,6 & 51,3 & 17,3 & 22,9 & 8,8 \\
\hline Mbo4 - economie en maatschappij & 3,7 & 74,7 & 22,7 & 45,2 & 12,2 \\
\hline Mbo4 - landbouw en natuur & 0,4 & 76,6 & 27,0 & 38,1 & 5,5 \\
\hline Mbo4 - techniek en ict & 2,6 & 62,5 & 21,5 & 30,6 & 7,8 \\
\hline Mb04 - zorg en dienstverlening & 1,4 & 48,0 & 13,9 & 22,7 & 8,1 \\
\hline Bachelor - economie en maatschappij & 5,1 & 66,9 & 19,1 & 32,9 & 4,6 \\
\hline Bachelor - landbouw en natuur & 5,5 & 66,7 & 21,3 & 24,6 & 2,5 \\
\hline Bachelor - techniek en ict & 3,0 & 49,2 & 9,7 & 15,6 & 2,1 \\
\hline Bachelor - zorg en onderwijs & 2,9 & 51,7 & 20,8 & 9,8 & 7,3 \\
\hline Master - economie en maatschappij & 6,0 & 62,3 & 39,3 & 33,3 & 4,7 \\
\hline Master - landbouw en natuur & 4,9 & 68,4 & 27,7 & 19,4 & 2,8 \\
\hline Master - techniek en ict & 2,7 & 54,0 & 29,6 & 21,5 & 2,0 \\
\hline Master - zorg en onderwijs & 3,3 & 36,2 & 18,9 & 9,8 & 4,5 \\
\hline
\end{tabular}

1) Cijfers voor wo hebben betrekking op 2015/2016. Bron: ROA (AIS) 